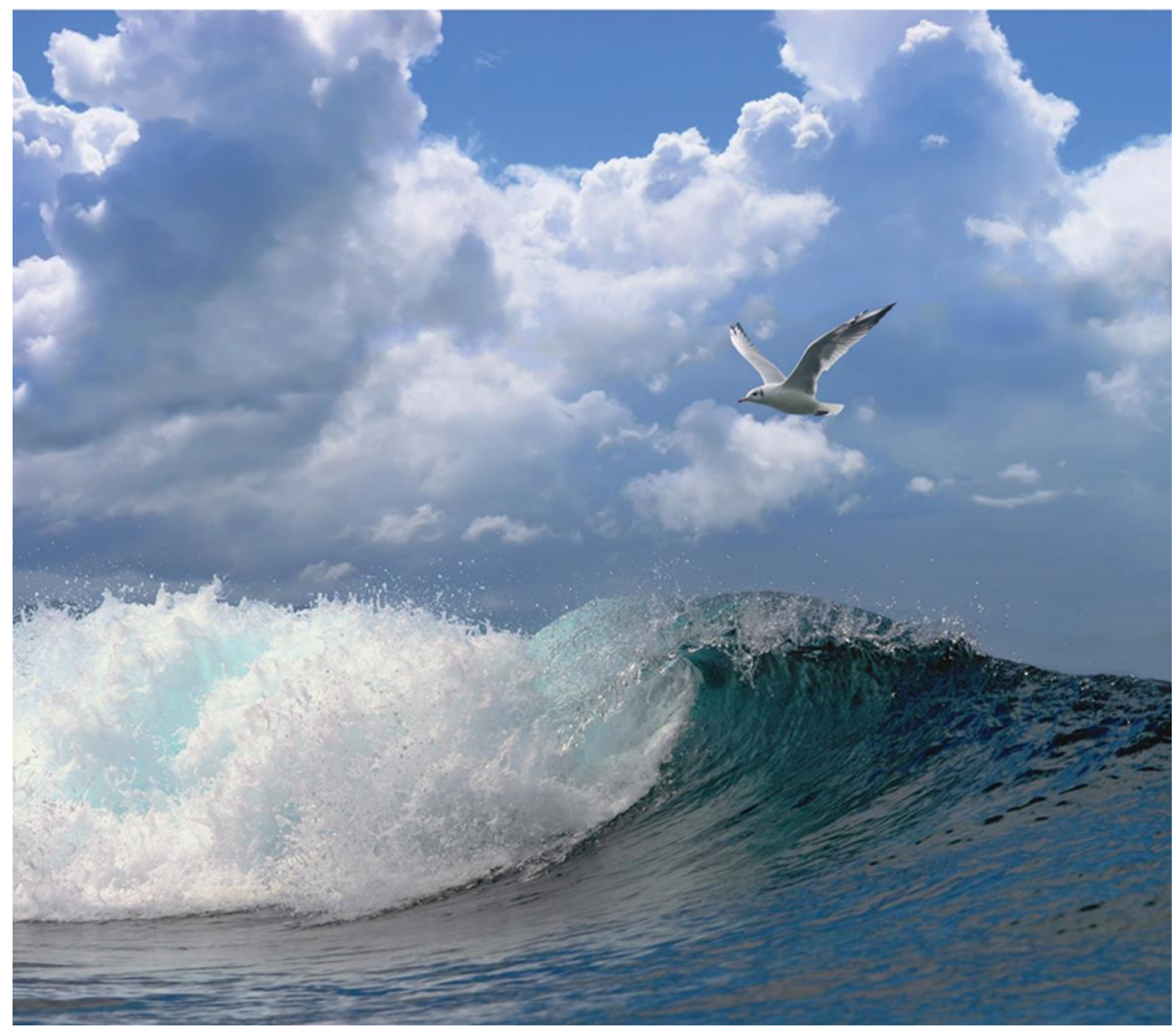

Naar een beoordelingssystematiek voor evaluatie van instandhoudingsdoelstellingen voor vissen in Natura 2000-gebieden in zoete en zoute rijkswateren 


\section{Naar een beoordelingssystematiek voor evaluatie van instandhoudings- doelstellingen voor vissen in Natura 2000-gebieden in zoete en zoute rijkswateren}


Keywords: Natura 2000, Habitatrichtlijn, trekvissen

Opdrachtgever: Rijkswaterstaat WVL

T.a.v.: M. Roos \& S. Stuijfzand

Postbus 1432

3500 GE Utrecht

Dit rapport is gratis te downloaden van https://doi.org/10.18174/512802

Wageningen Marine Research verstrekt geen gedrukte exemplaren van rapporten.

Wageningen Marine Research is ISO 9001:2015 gecertificeerd.

\section{(c) Wageningen Marine Research}

Wageningen Marine Research, instituut binnen de rechtspersoon Stichting Wageningen Research, hierbij vertegenwoordigd door Dr. M.C.Th. Scholten, Algemeen directeur

KvK nr. 09098104,

WMR BTW nr. NL 8113.83.696.B16. Code BIC/SWIFT address: RABONL2U IBAN code: NL 73 RABO 0373599285
Wageningen Marine Research aanvaardt geen aansprakelijkheid voor gevolgschade, noch voor schade welke voortvloeit uit toepassingen van de resultaten van werkzaamheden of andere gegevens verkregen van Wageningen Marine Research. Opdrachtgever vrijwaart Wageningen Marine Research van aanspraken van derden in verband met deze toepassing. Alle rechten voorbehouden. Niets uit deze uitgave mag weergegeven en/of gepubliceerd worden, gefotokopieerd of op enige andere manier gebruikt worden zonder schriftelijke toestemming van de uitgever of auteur. 


\section{Inhoud}

\section{Samenvatting}

$1 \quad$ Inleiding

1.1 Doel

1.2 Instandhoudingsdoelstellingen

1.3 Links met andere rapportages

1.4 Uitgangspunten

1.5 Aanpak

$\begin{array}{lll}2.1 & \text { Inleiding } & 15\end{array}$

$\begin{array}{lll}2.2 & \text { Overzicht van datasets (longlist) } & 15\end{array}$

2.2.1 Zoete wateren en overgangswateren 15

$\begin{array}{ll}2.2 .2 & \text { Zoute wateren }\end{array}$

$\begin{array}{lll}2.3 & \text { Selectie van dataseries (shortlist) } & 20\end{array}$

$\begin{array}{lll}2.3 .1 & \text { Selectiecriteria } & 21\end{array}$

$\begin{array}{lll}\text { 2.3.2 } & \text { Geselecteerde data } & 24\end{array}$

$3 \quad$ Statistiek en evaluatie $r$

$\begin{array}{lll}3.1 & \text { Inleiding } & 27\end{array}$

$\begin{array}{lll}3.1 .1 & \text { Achtergrond: protocollen voor statistische analyse } & 27\end{array}$

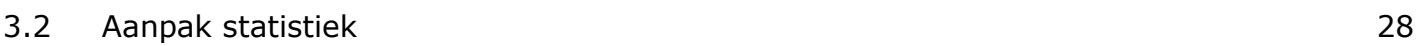

$\begin{array}{lll}3.2 .1 & \text { Stap 1. Stellen van de juiste vraag } & 28\end{array}$

3.2.2 Stap 2. Visualiseer het experimentele design (de datapunten in de ruimte) 28

$\begin{array}{lll}3.2 .3 & \text { Stap 3. Voer data-exploratie uit } & 28\end{array}$

3.2.4 Stap 4. Identificeer de afhankelijkheden binnen de data 29

3.2.5 Stap 5. Presenteer het statistische model 29

3.2.6 Stap 6. Fit het model $\quad 30$

$\begin{array}{lll}3.2 .7 & \text { Stap 7. Valideer het model } & 30\end{array}$

3.2.8 Stap 8. Interpreteer en presenteer de numerieke output van het model 30

3.2.9 Stap 9. Creëer een visuele voorstelling van het model. 30

$\begin{array}{lll}3.3 & \text { Toepassing statistiek op twee voorbeelden } & 31\end{array}$

3.3.1 Voorbeeld van GLM op getelde aantallen: zeeprik in de Voordelta 31

3.3.2 Voorbeeld van GLM op de aan-/afwezigheid van de soort in een vangst: rivierdonderpad in het Haringvliet $\quad 34$

$\begin{array}{lll}3.4 & \text { Aanpak evaluatie doelbereik } & 37\end{array}$

$\begin{array}{lll}3.4 .1 & \text { Twee voorbeelden } & 38\end{array}$

$\begin{array}{lll}3.5 & \text { Template voor rapportage } & 38\end{array}$

$4 \quad$ Samenvatting beoordelingsmethodiek $\quad 39$

$\begin{array}{lll}4.1 & \text { Uitgangspunten } & 39\end{array}$

$\begin{array}{lll}4.2 & \text { Stap 1. Dataselectie } & 39\end{array}$

$\begin{array}{lll}4.3 & \text { Stap 2. Statistische analyse } & 39\end{array}$

$\begin{array}{lll}4.4 & \text { Stap 3. Evaluatie doelbereik } & 40\end{array}$ 
Bijlage 1 Instandhoudingsdoelstellingen

Bijlage 2 Template evaluatie

Bijlage $3 \quad$ Kaarten per Natura 2000-gebied

Biesbosch

Grensmaas

Haringvliet 50

Hollands Diep

IJsselmeer

Markermeer \& IJmeer

Rijntakken

Veluwe Randmeren

Vlakte van de Raan

Voordelta

Waddenzee 


\section{Samenvatting}

\section{Achtergrond}

Elk Natura 2000-gebied in Nederland kent een aanwijzingsbesluit en een beheerplan waarin staat welke instandhoudingsdoelstellingen en maatregelen voor habitattypen en soorten zijn vastgesteld. Aan het einde van de beheerplanperiode (na 6 jaar), en eventueel al halverwege (na 3 jaar), moet een beheerplan geëvalueerd worden om vast te stellen in hoeverre de gestelde instandhoudingsdoelstellingen zijn gehaald. In dit rapport is een beoordelingssystematiek ontwikkeld voor alle 50 soortgebiedscombinaties voor vissen, en zijn geschikte data geselecteerd om deze behoordeling uit te voeren. Dit wordt bv. gedaan voor zalm in het Natura 2000-gebied Grensmaas, zeeprik in het Hollands Diep of fint in de Waddenzee. Zo kan voor de rijkswateren beoordeeld worden of de gestelde Natura 2000instandhoudingsdoelstellingen per soort zijn behaald of niet, of dat informatie voor beoordeling ontbreekt.

\section{Ontwikkelde methodiek}

Een instandhoudingsdoelstelling is opgebouwd uit 3 aspecten die getoetst moeten worden: Omvang leefgebied, Kwaliteit leefgebied en Populatie. In dit rapport wordt alleen gekeken naar het aspect Populatie. De andere aspecten zijn geen onderwerp van dit rapport. Het referentiejaar voor de instandhoudingsdoelstelling voor de populatie is het jaar van aanwijzing van het Natura 2000-gebied (bv. 2008 voor de Voordelta, 2010 voor IJsselmeer, etc.). Bij een verbeterdoelstelling moet vastgesteld worden of de populatie t.o.v. het referentiejaar is toegenomen. Bij een behoudsdoelstelling moet de populatie ten minste even groot zijn gebleven.

Uit een zo compleet mogelijk overzicht van zoet- en zoutwaterdata zijn door een expert (visecoloog) één of meerdere dataseries geselecteerd die representatief zijn voor de soort in een bepaald Natura 2000gebied. Deze selectie is gemaakt op basis van een aantal selectiecriteria met betrekking tot bemonsteringslocatie, -seizoen, lengte van dataserie, vangstmethode, etc. Ook is daarbij rekening gehouden met de functie van het gebied voor de soort. Een gebied kan een foerageerfunctie hebben, dienen als opgroeigebied, als paaigebied, als corridor, of kan gedurende de hele levenscyclus worden gebruikt.

Afhankelijk van de kwaliteit van de data wordt een van onderstaande methodes gebruikt om trends te bepalen:

- General Linear Model (GLM) op getelde aantallen. Dit heeft de voorkeur, omdat het een trend in aantallen oplevert. De methode kan toegepast worden op de werkelijk getelde aantallen of als loglineaire regressie. De methode kan echter alleen toegepast worden op soorten die veel gevangen worden, d.w.z. een bestand met niet te veel nullen.

- $\quad$ GLM op de aan-/afwezigheid van de soort in een vangst.

Het doelbereik wordt bepaald door de statistische uitkomst van de trendanalyse te vergelijken met de instandhoudingsdoelstelling voor die bepaalde Habitatrichtlijn-vissoort in een Natura 2000-gebied. Als het doel bijvoorbeeld 'uitbreiding populatie' is, dan is het doel bereikt als aangetoond kan worden dat de populatie statistisch gezien een significant positieve trend vertoont ten opzichte van het referentiejaar.

De statistische resultaten moeten vervolgens geïnterpreteerd worden door een expert. Voor de interpretatie wordt rekening gehouden met o.a. de lange termijn dataseries en met resultaten uit eventuele eerdere evaluaties. Expert judgement kan toelichting geven op de geconstateerde trends (hoe 
sterk is de toe- of afname, wat is hiervan de achterliggende reden, etc.) en geeft een context waarin de trends gezien moeten worden.

Voor een overzichtelijke presentatie van de resultaten per soort-gebiedscombinatie is een simpel template ontwikkeld waarin gegevens gerapporteerd kunnen worden.

We raden aan bij daadwerkelijke evaluatie van beheerplannen de analyse te laten doen door iemand die de data goed kent en op de hoogte is van alle eventuele valkuilen, zoals bijvoorbeeld verandering van vistuig, vangstlocatie, trendbreuken etc. 


\section{$1 \quad$ Inleiding}

\section{$1.1 \quad$ Doel}

Rijkswaterstaat heeft WMR gevraagd een systematiek te ontwikkelen waarmee de instandhoudingsdoelstellingen voor vissoorten van de Habitatrichtlijn Annex II binnen Natura 2000gebieden op een eenduidige manier kunnen worden geëvalueerd. Het gaat hierbij om 14 Natura 2000gebieden in de rijkswateren (12 voortouwgebieden ${ }^{1}$ van Rijkswaterstaat, 1 voortouwgebied van de Provincie Gelderland en 1 van het ministerie van LNV) waarvoor instandhoudingsdoelstellingen gelden voor HR Annex II vissoorten (zie Tabel 1, Tabel 2). In totaal gaat het om 50 soort-gebiedscombinaties (Tabel 3) (Figuur 1).

\subsection{Instandhoudingsdoelstellingen}

Natura 2000-gebieden in Nederland kennen een beheerplan waarin staat welke doelen en maatregelen voor habitattypen en soorten zijn vastgesteld (Tabel 1). Na afloop van de beheerplanperiode (na 6 jaar) of eventueel halverwege (na 3 jaar) moet kunnen worden beoordeeld of de genomen maatregelen effectief zijn geweest en of de instandhoudingsdoelstellingen zijn gehaald. Een standaardmethodiek om het doelbereik voor soorten en habitattypen te beoordelen is nog niet voorhanden, omdat veel Natura 2000-gebieden en hun beheerplannen nog niet zo lang bestaan. Meer informatie over de systematiek van de Habitatrichtlijn (HR) is te vinden online bij Kenniscentrum InfoMil van de rijksoverheid ${ }^{2}$.

\section{Voortouwnemers}

Wanneer een gebied meerdere beheerders kent, is de organisatie die het grootste deel van het gebied beheert doorgaans de 'voortouwnemer'. De voortouwnemer draagt zorg voor de totstandkoming van het beheerplan. Rijkswaterstaat (RWS) is voortouwnemer van 12 Natura 2000-gebieden (4 op zee (kust) en 8 gebieden in de binnenwateren) met instandhoudingsdoelstellingen voor Habitatrichtlijn Annex IIvissoorten. Verder zijn er nog 2 Natura 2000-gebieden in rijkswateren waarvan RWS niet de voortouwnemer is: Rijntakken (provincie Gelderland) en Biesbosch (Min LNV). In totaal wordt in dit rapport gekeken naar 14 gebieden in de rijkswateren waarin doelen voor vissoorten zijn gesteld. In Tabel 2 is een beknopt overzicht gegeven van deze Natura 2000-gebieden en voor welke vissoort er doelen zijn gesteld.

\section{Instandhoudingsdoelstellingen}

In Tabel 3 staan de doelen voor het aspect Populatie per soort per gebied verkort weergegeven (zie Min LNV, 2009). Een instandhoudingsdoelstelling voor een soort in een Natura 2000-gebied is opgebouwd uit 3 aspecten die getoetst moeten worden:

- Omvang leefgebied

- Kwaliteit leefgebied

- Populatie

Een voorbeeld: voor de zeeprik in de Waddenzee is het doel:

- omvang leefgebied: '='

- kwaliteit leefgebied: '='

- populatie: '>'

\footnotetext{
${ }^{1}$ Voortouwgebied: gebied dat als Natura 2000-gebied is aangemeld of aangewezen en waar RWS, LNV, of een provincie voortouwnemer is. De rol van voortouwnemer is vooral die van eerst verantwoordelijke bij het opstellen van het beheerplan (zie definitie in Richtlijn Projectmonitoring RWS: https://edepot.wur.nl/296135).

2 https://www.infomil.nl/onderwerpen/lucht-water/handboek-water/thema\%27s/waterkwaliteit-0/doelstellingen/
} 
Dit betekent dat bij een evaluatie van het beheerplan getoetst moet worden of de omvang van het leefgebied behouden is gebleven, of de kwaliteit van het leefgebied behouden is gebleven, en of de populatie is toegenomen.

In dit rapport wordt alleen ingegaan op het laatste aspect (Populatie); de andere twee aspecten (Omvang leefgebied en Kwaliteit leefgebied) worden niet behandeld.

In het algemeen zijn de volgende doelen voor Populatie mogelijk (Min LNV, 2009, p5):

- '=' behoud;

- $\quad$ '>' uitbreiding of verbetering;

Het doel '<' (verslechtering) komt uiteraard niet voor. De uitgebreidere omschrijving van de doelen staan in de Aanwijzingsbesluiten per Natura 2000-gebied, en zijn uitgewerkt in de Natura 2000beheerplannnen (Tabel 1, Tabel 3).

Evaluatie van doelen

Dit rapport is bedoeld als een technische handleiding om de instandhoudingsdoelstellingen voor een aantal HR-vissoorten in een aantal Natura 2000-gebieden te kunnen beoordelen. In totaal gaat het om 50 vissoort-gebiedscombinaties voor de Annex II soorten uit de Habitatrichtlijn (HR) (Tabel 3) in deze gebieden.

\section{Template rapportage}

In dit rapport is een eenvoudig template opgenomen (Bijlage 2) met als doel de toekomstige rapportages over populatietrends van HR-vissoorten in Natura 2000-gebieden op eenduidige manier op te stellen. 
Tabel 1. Natura 2000-gebieden met links naar beheerplannen, aanwijzingsdocumenten en andere informatie.

\begin{tabular}{|c|c|c|c|c|}
\hline $\begin{array}{l}\text { Natura } 2000- \\
\text { gebied } \\
\text { (code) }\end{array}$ & Natura 2000-gebiedsinfo & Beheerplan & $\begin{array}{l}\text { Voortouw- } \\
\text { nemer }\end{array}$ & $\begin{array}{l}\text { Jaar } \\
\text { aan- } \\
\text { wijzing }\end{array}$ \\
\hline $\begin{array}{l}\text { Waddenzee } \\
\text { (incl Eems- } \\
\text { Dollard) (1) }\end{array}$ & $\begin{array}{l}\text { https://www.synbiosys.alterra. } \\
\text { nl/natura2000/gebiedendataba } \\
\text { se.aspx?subj=n2k\&groep=1\&id } \\
=\text { n2k1 }\end{array}$ & $\begin{array}{l}\text { https://www.bij12.nl/assets/Wadd } \\
\text { enzee-beheerplan.pdf }\end{array}$ & RWS & 2009 \\
\hline $\begin{array}{l}\text { Noordzeekust- } \\
\text { zone ( } 7)\end{array}$ & $\begin{array}{l}\text { https://www.synbiosys.alterra. } \\
\text { nl/natura2000/gebiedendataba } \\
\text { se.aspx?subj=n2k\&groep=2\&id } \\
=\text { n2k7 }\end{array}$ & $\begin{array}{l}\text { https://www.synbiosys.alterra.nl/n } \\
\text { atura2000/gebiedendatabase.aspx } \\
\text { ?subj=n2k\&groep=2\&id=n2k7 }\end{array}$ & RWS & 2009 \\
\hline $\begin{array}{l}\text { IJsselmeer } \\
(72)\end{array}$ & $\begin{array}{l}\text { https://www.synbiosys.alterra. } \\
\text { nl/natura2000/gebiedendataba } \\
\text { se.aspx?subj=n2k\&groep=2\&id } \\
=n 2 k 72\end{array}$ & $\begin{array}{l}\text { https://www. noord- } \\
\text { holland.nl/dsresource?objectid =94 } \\
\text { a2110e-2440-42af-9b7b- } \\
\text { f23e3a9f47cb\&type=PDF }\end{array}$ & RWS & 2010 \\
\hline $\begin{array}{l}\text { Markermeer \& } \\
\text { IJmeer (73) }\end{array}$ & $\begin{array}{l}\text { https://www.synbiosys.alterra. } \\
\text { nl/natura2000/gebiedendataba } \\
\text { se.aspx?subj=n2k\&groep=4\&id } \\
=\text { n2k73 }\end{array}$ & $\begin{array}{l}\text { https://www. noord- } \\
\text { holland.nl/dsresource?objectid=b6 } \\
\text { 8235fa-eb1b-4bcd-9538- } \\
\text { efae4003c2ef\&type=PDF }\end{array}$ & RWS & 2010 \\
\hline $\begin{array}{l}\text { Zwarte Meer } \\
\text { (74) }\end{array}$ & $\begin{array}{l}\text { https://www.synbiosys.alterra. } \\
\text { nl/natura2000/gebiedendataba } \\
\text { se.aspx?subj=n2k\&groep=4\&id } \\
=\text { n2k74 }\end{array}$ & $\begin{array}{l}\text { http://www.rwsnatura2000.nl/Gebi } \\
\text { eden/IJsselmeergebied/IJSS_Docu } \\
\text { menten/HandlerDownloadFiles.ash } \\
\text { x?idnv=992640 }\end{array}$ & RWS & 2010 \\
\hline $\begin{array}{l}\text { Veluwe rand- } \\
\text { meren (76) }\end{array}$ & $\begin{array}{l}\text { https://www.synbiosys.alterra. } \\
\text { nl/natura2000/gebiedendataba } \\
\text { se.aspx?subj=n2k\&groep=4\&id } \\
=n 2 k 76\end{array}$ & $\begin{array}{l}\text { http://www.rwsnatura2000.nl/Gebi } \\
\text { eden/IJsselmeergebied/IJSS_Docu } \\
\text { menten/HandlerDownloadFiles.ash } \\
\text { x?idnv=992639 }\end{array}$ & RWS & 2010 \\
\hline $\begin{array}{l}\text { Haringvliet } \\
(109)\end{array}$ & $\begin{array}{l}\text { https://www.synbiosys.alterra. } \\
\text { nl/natura2000/gebiedendataba } \\
\text { se.aspx?subj=n2k\&groep=9\&id } \\
\text { =n2k109 }\end{array}$ & $\begin{array}{l}\text { http://rwsnatura2000.nl/Gebieden } \\
\text { /DW_Deltawateren/documenten+d } \\
\text { eltawateren/HandlerDownloadFiles. } \\
\text { ashx?idnv }=64825\end{array}$ & RWS & 2015 \\
\hline $\begin{array}{l}\text { Hollands Diep } \\
\text { (111) }\end{array}$ & $\begin{array}{l}\text { https://www.synbiosys.alterra. } \\
\text { nl/natura2000/gebiedendataba } \\
\text { se.aspx?subj=n2k\&groep=9\&id } \\
=\text { n2k111 }\end{array}$ & $\begin{array}{l}\text { http://rwsnatura2000.nl/Gebieden } \\
\text { /DW_Deltawateren/documenten+d } \\
\text { eltawateren/HandlerDownloadFiles. } \\
\text { ashx?idnv }=648252\end{array}$ & RWS & 2013 \\
\hline $\begin{array}{l}\text { Voordelta } \\
(113)\end{array}$ & $\begin{array}{l}\text { https://www.synbiosys.alterra. } \\
\text { nl/natura2000/gebiedendataba } \\
\text { se.aspx?subj=n2k\&groep=9\&id } \\
=n 2 k 113\end{array}$ & $\begin{array}{l}\text { http://rwsnatura2000.nl/Gebieden } \\
\text { ND_Voordelta/VD_Documenten/H } \\
\text { andlerDownloadFiles.ashx?idnv=59 } \\
3295\end{array}$ & RWS & 2008 \\
\hline $\begin{array}{l}\text { Westerschelde } \\
\text { \& Saeftinghe } \\
(122)\end{array}$ & $\begin{array}{l}\text { https://www.synbiosys.alterra. } \\
\text { nl/natura2000/gebiedendataba } \\
\text { se.aspx?subj=n2k\&groep=10\&i } \\
d=n 2 k 122\end{array}$ & $\begin{array}{l}\text { http://rwsnatura2000.nl/Gebieden } \\
\text { /DW_Deltawateren/documenten+d } \\
\text { eltawateren/HandlerDownloadFiles. } \\
\text { ashx?idnv }=648256\end{array}$ & RWS & 2010 \\
\hline $\begin{array}{l}\text { Grensmaas } \\
(152)\end{array}$ & $\begin{array}{l}\text { https://www.synbiosys.alterra. } \\
\text { nl/natura2000/gebiedendataba } \\
\text { se.aspx?subj=n2k\&groep=12\&i } \\
\text { d=n2k152 }\end{array}$ & $\begin{array}{l}\text { https://pureportal.inbo.be/portal/fi } \\
\text { les/14293204/beheerplan_natura_- } \\
\text { 2000_grensmaas2.pdf }\end{array}$ & RWS & 2013 \\
\hline $\begin{array}{l}\text { Vlakte van de } \\
\text { Raan (163) }\end{array}$ & $\begin{array}{l}\text { https://www.synbiosys.alterra. } \\
\text { nl/natura2000/gebiedendataba } \\
\text { se.aspx?subj=n2k\&groep=10\&i } \\
d=n 2 k 163\end{array}$ & $\begin{array}{l}\text { http://rwsnatura2000.nl/Gebieden } \\
\text { /VvdR_Vlakte+van+de+Raan/Vvd } \\
\text { R_Documenten/HandlerDownloadFi } \\
\text { les.ashx?idnv =593304 }\end{array}$ & RWS & 2010 \\
\hline $\begin{array}{l}\text { Rijntakken } \\
\text { (38) }\end{array}$ & $\begin{array}{l}\text { https://www.synbiosys.alterra. } \\
\text { nl/natura2000/gebiedendataba } \\
\text { se.aspx?subj=n2k\&groep=6\&id } \\
=\text { n2k38 }\end{array}$ & $\begin{array}{l}\text { https://www.bij12.nl/assets/17050 } \\
\text { 4_N2000-ontwerp-beheerplan- } \\
\text { Rijntakken_dig.pdf }\end{array}$ & $\begin{array}{l}\text { Provincie } \\
\text { Gelderland }\end{array}$ & 2014 \\
\hline $\begin{array}{l}\text { Biesbosch } \\
(112)\end{array}$ & $\begin{array}{l}\text { https://www.synbiosys.alterra. } \\
\text { nl/natura2000/gebiedendataba } \\
\text { se.aspx?subj=n2k\&groep=11\&i } \\
\text { d=n2k112 }\end{array}$ & $\begin{array}{l}\text { https://www.bij12.nl/assets/112- } \\
\text { Biesbosch-ontwerpbeheerplan- } \\
\text { mei-2016.pdf }\end{array}$ & $\begin{array}{l}\text { Ministerie } \\
\text { LNV }\end{array}$ & 2013 \\
\hline
\end{tabular}


Tabel 2. Overzicht van de Habitatrichtlijn-vissoorten waarvoor instandhoudingsdoelstellingen zijn opgesteld die binnen dit rapport nader worden bekeken, per Natura 2000-gebied. Meer informatie over HR-soorten staat in de profieldocumenten (Tabel 4) en meer informatie over de gebieden staat in Tabel 1 .

\begin{tabular}{|c|c|c|c|c|c|c|c|c|c|c|c|c|c|c|c|}
\hline & $\begin{array}{l}\frac{-}{0} \\
\text { ㅇ } \\
\frac{0}{y} \\
\frac{0}{0}\end{array}$ & 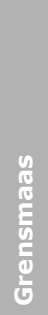 & 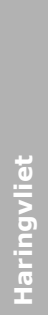 & $\begin{array}{l}\frac{0}{0} \\
\frac{0}{0} \\
\frac{n}{0} \\
\frac{0}{10} \\
\frac{10}{0} \\
\text { 우 }\end{array}$ & 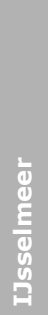 & 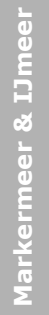 & 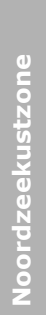 & 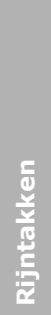 & 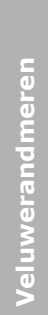 & 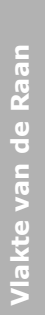 & $\begin{array}{l}\frac{\$}{0} \\
\frac{0}{0} \\
\frac{0}{2} \\
\end{array}$ & 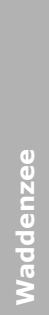 & 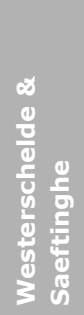 & 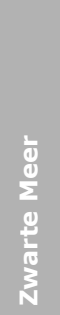 & 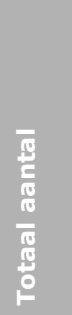 \\
\hline Bittervoorn & & & $x$ & & & & & & & & & & & & 1 \\
\hline Elft & $x$ & & $x$ & $x$ & & & & $x$ & & & $x$ & & & & 5 \\
\hline Fint & $x$ & & $x$ & $x$ & & & $x$ & & & $x$ & $x$ & $x$ & $x$ & & 8 \\
\hline $\begin{array}{l}\text { Grote } \\
\text { modderkruiper }\end{array}$ & $x$ & & & & & & & & & & & & & $\mathrm{x}$ & 2 \\
\hline $\begin{array}{l}\text { Kleine } \\
\text { modderkruiper }\end{array}$ & $x$ & & & & & & & & $x$ & & & & & $x$ & 3 \\
\hline Rivierdonderpad & $x$ & $x$ & $x$ & & $x$ & $x$ & & & $x$ & & & & & $x$ & 7 \\
\hline Rivierprik & $x$ & $x$ & $x$ & $x$ & & & $x$ & $x$ & & $x$ & $x$ & $x$ & $x$ & & 10 \\
\hline Zalm & $x$ & $x$ & $x$ & $x$ & & & & $x$ & & & & & & & 5 \\
\hline Zeeprik & $x$ & & $x$ & $x$ & & & $x$ & $x$ & & $x$ & $x$ & $x$ & $x$ & & 9 \\
\hline Totaal aantal & 8 & 3 & 7 & 5 & 1 & 1 & 3 & 4 & 2 & 3 & 4 & 3 & 3 & 3 & 50 \\
\hline
\end{tabular}


Tabel 3. Lijst van soort-gebiedscombinaties die in dit rapport nader worden bekeken. Voor elk relevant Natura 2000-gebied staat per HR vissoort de instandhoudingsdoelstelling vermeld, evenals de voortouwnemer. De instandhoudingsdoelstelling bestaat uit drie aspecten, waarvan hier alleen 'populatie' is weergegeven. Doel: = behoud; > uitbreiding of verbetering. NB: in Biesbosch en Rijntakken zijn ook instandhoudingsdoelstellingen voor andere vissoorten gesteld, maar dit betreft soorten die niet of beperkt in rijkswateren voorkomen en waar dit rapport geen betrekking op heeft.

\begin{tabular}{|c|c|c|c|}
\hline Natura 2000-gebied & Soort & $\frac{0}{\frac{10}{20}}$ & $\begin{array}{l}\text { Voortouw- } \\
\text { nemer }\end{array}$ \\
\hline Waddenzee & Zeeprik & $>$ & RWS \\
\hline Waddenzee & Rivierprik & $>$ & RWS \\
\hline Waddenzee & Fint & $>$ & RWS \\
\hline Noordzeekustzone & Zeeprik & $>$ & RWS \\
\hline Noordzeekustzone & Rivierprik & $>$ & RWS \\
\hline Noordzeekustzone & Fint & $>$ & RWS \\
\hline IJsselmeer & Rivierdonderpad & $=$ & RWS \\
\hline Markermeer \& IJmeer & Rivierdonderpad & $=$ & RWS \\
\hline Zwarte Meer & Grote modderkruiper & $=$ & RWS \\
\hline Zwarte Meer & Kleine modderkruiper & $=$ & RWS \\
\hline Zwarte Meer & Rivierdonderpad & $=$ & RWS \\
\hline Veluwerandmeren & Kleine modderkruiper & $=$ & RWS \\
\hline Veluwerandmeren & Rivierdonderpad & $=$ & RWS \\
\hline Haringvliet & Zeeprik & $>$ & RWS \\
\hline Haringvliet & Rivierprik & $>$ & RWS \\
\hline Haringvliet & Elft & $>$ & RWS \\
\hline Haringvliet & Fint & $>$ & RWS \\
\hline Haringvliet & Zalm & $>$ & RWS \\
\hline Haringvliet & Bittervoorn & $=$ & RWS \\
\hline Haringvliet & Rivierdonderpad & $=$ & RWS \\
\hline Hollands Diep & Zeeprik & $>$ & RWS \\
\hline Hollands Diep & Rivierprik & $>$ & RWS \\
\hline Hollands Diep & Elft & $>$ & RWS \\
\hline Hollands Diep & Fint & $>$ & RWS \\
\hline Hollands Diep & Zalm & $>$ & RWS \\
\hline Voordelta & Zeeprik & $>$ & RWS \\
\hline Voordelta & Rivierprik & $>$ & RWS \\
\hline Voordelta & Elft & $>$ & RWS \\
\hline Voordelta & Fint & $>$ & RWS \\
\hline Westerschelde \& Saeftinghe & Zeeprik & $>$ & RWS \\
\hline Westerschelde \& Saeftinghe & Rivierprik & $>$ & RWS \\
\hline Westerschelde \& Saeftinghe & Fint & $>$ & RWS \\
\hline Grensmaas & Rivierprik & $>$ & RWS \\
\hline Grensmaas & Zalm & $>$ & RWS \\
\hline Grensmaas & Rivierdonderpad & $=$ & RWS \\
\hline Vlakte van de Raan & Zeeprik & $>$ & RWS \\
\hline Vlakte van de Raan & Rivierprik & $>$ & RWS \\
\hline Vlakte van de Raan & Fint & $>$ & RWS \\
\hline Rijntakken & Zeeprik & $>$ & Prov. Gelderland \\
\hline Rijntakken & Rivierprik & $>$ & Prov. Gelderland \\
\hline Rijntakken & Elft & $>$ & Prov. Gelderland \\
\hline Rijntakken & Zalm & $>$ & Prov. Gelderland \\
\hline Biesbosch & Zeeprik & $>$ & LNV \\
\hline Biesbosch & Rivierprik & $>$ & LNV \\
\hline Biesbosch & Elft & $>$ & LNV \\
\hline Biesbosch & Fint & $>$ & LNV \\
\hline Biesbosch & Zalm & $>$ & LNV \\
\hline Biesbosch & Rivierdonderpad & $=$ & LNV \\
\hline
\end{tabular}




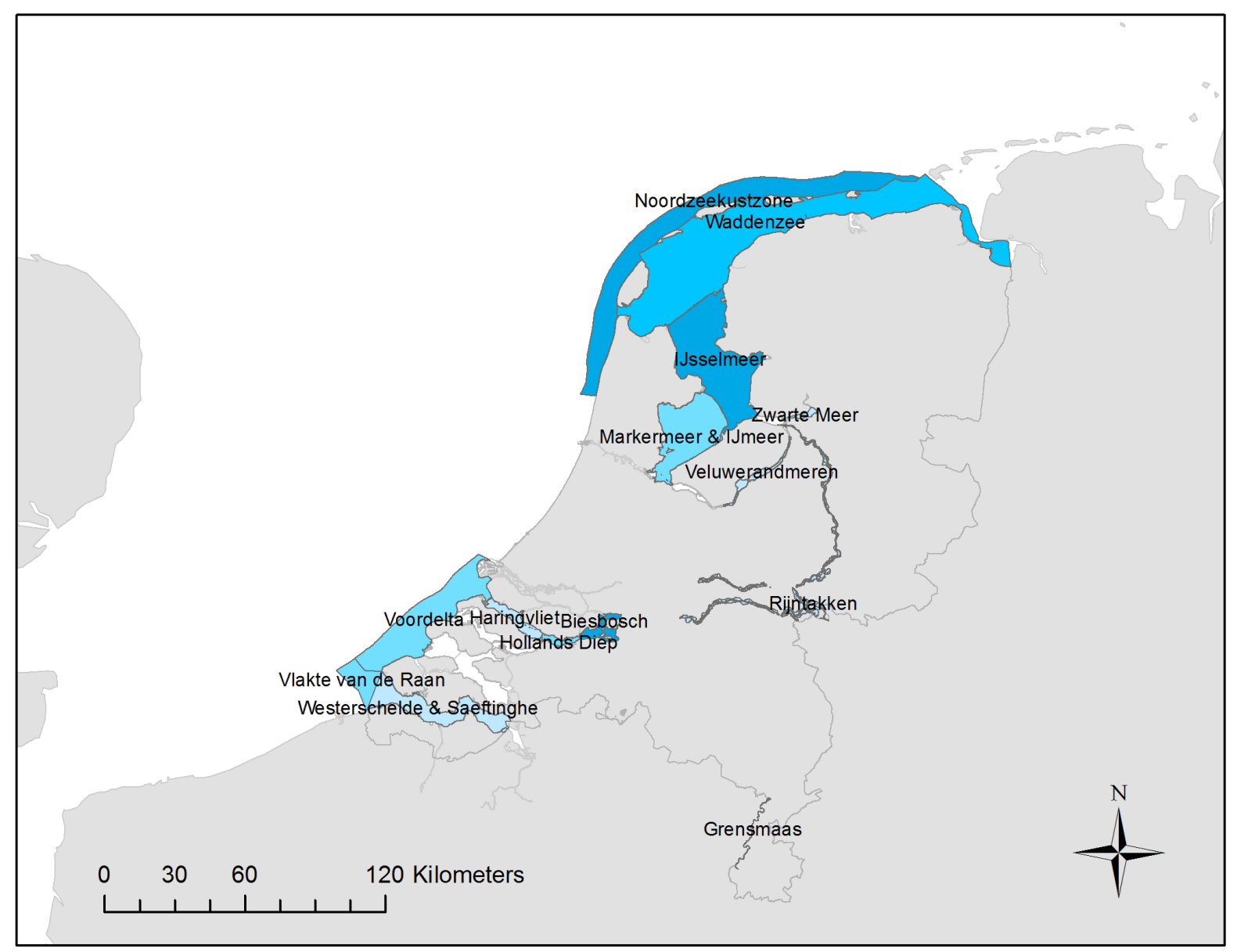

Figuur 1. Overzicht van de verschillende Natura 2000-gebieden die in dit rapport behandeld worden.

Tabel 4. Links naar de profieldocumenten per soort.

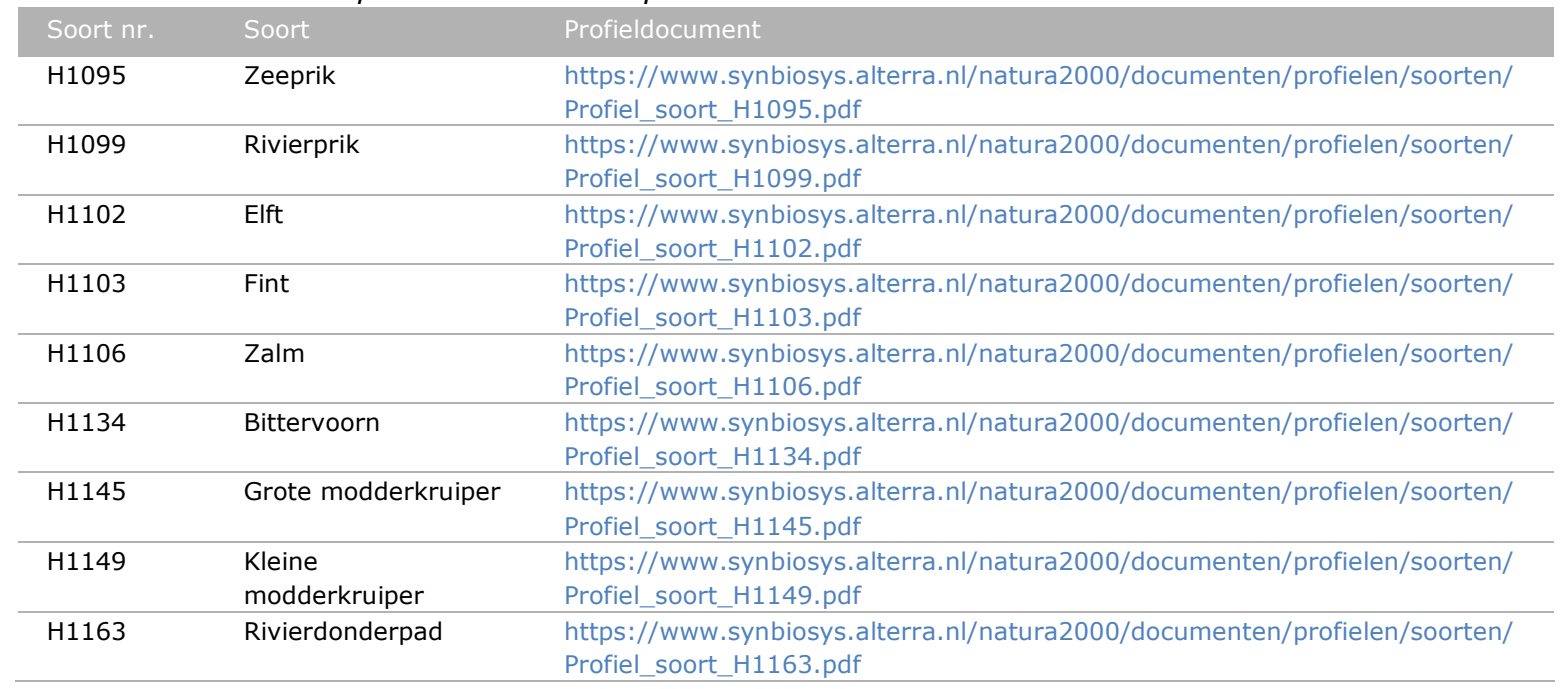




\subsection{Links met andere rapportages}

Hoewel de evaluaties van Natura 2000-beheerplannen op zichzelf staan, en alleen gericht zijn op de instandhoudingsdoelstellingen uit het aanwijzingsbesluit voor het gebied, zijn ze verbonden met twee andere rapportages: de Habitatrichtlijn (HR) artikel 17-rapportage ${ }^{3}$ en de Standaardgegevensformulieren.

- De HR-artikel $17^{3}$ rapportage wordt eens in de 6 jaar uitgevoerd door het ministerie van LNV om de landelijke staat van instandhouding van soorten en habitattypen te rapporteren aan de Europese Commissie (EC). Binnen de HR-artikel 17 rapportage moet o.a. gerapporteerd worden over trends per soort op landelijk niveau en binnen het geheel aan Natura 2000-gebieden. Informatie uit de evaluatie van Natura 2000-beheerplannen wordt meegenomen bij het opstellen van de landelijke artikel 17-rapportage. In 2019 vond de meest recente rapportage plaats.

- Standaardgegevensformulieren (Standard Data Forms, SFDs) dienen als een soort paspoort per gebied voor de EC en worden ingevuld door het ministerie van LNV voor elk nieuw Natura 2000gebied. Ze bevatten basisinformatie zoals de ligging, de grootte, en voor welke habitattypen en soorten het gebied is aangemeld en hoe dit bijdraagt aan de landelijke doelen. Deze formulieren dienen geactualiseerd te worden indien er veranderingen zijn (bv. wanneer de populatie van een bepaalde vissoort is toegenomen), zonder dat hiervoor een bepaalde cyclus van toepassing is. De gegevens worden in Europees verband gebruikt (https://www.eea.europa.eu/data-andmaps/data/natura-9).

\section{$1.4 \quad$ Uitgangspunten}

De volgende uitgangspunten zijn gehanteerd:

- Het referentiejaar voor de instandhoudingsdoelstelling is het jaar waarin een Natura 2000gebied is aangewezen (bv 2010 voor het IJsselmeer). Bij een verbeterdoelstelling moet vastgesteld worden of de populatie, op het moment van evaluatie (na 3 of 6 jaar), een positieve trend vertoont t.o.v. van het referentiejaar. Bij een behoudsdoelstelling moet de populatie ten minste even groot zijn gebleven.

- $\quad$ De beoordelingsmethodiek sluit waar mogelijk aan bij de methodiek voor de HR-artikel 17 rapportage en voor de Standaardgegevensformulieren, zodat uitwisseling van informatie mogelijk is.

- $\quad$ De analysemethoden zijn in overleg met het Centraal Bureau voor de Statistiek (CBS) bepaald. Gestreefd wordt naar een eenduidige statistische methode om trends in populatiegrootte te berekenen, die door WMR en RWS al dan niet met hulp van het CBS kan worden uitgevoerd.

- Gezien de onnauwkeurigheden die vismeetnetten vaak met zich meebrengen waar het zeldzame soorten betreft, heeft de ontwikkeling van een eenvoudige (transparante, pragmatische) beoordelingssystematiek de voorkeur boven een ingewikkelde (niet transparante en waarschijnlijk schijnnauwkeurige) systematiek. In de loop der tijd, wanneer dataseries langer worden, zou het mogelijk kunnen zijn dat voor een aantal soort-gebiedscombinaties overgestapt kan worden van de trendanalyse van aan/afwezigheid naar trendanalyse op aantallen.

Het volgende punt is als afbakening gehanteerd:

- Het is niet mogelijk aan te sluiten op de vismaatlatten van de Kaderrichtlijn Water (KRW). De KRW kijkt namelijk niet naar soorten, maar naar gemeenschappen. Wel geldt dat maatregelen zowel voor soorten als gemeenschappen van belang zijn, maar dit staat los van de beoordeling van de doelen.

\footnotetext{
${ }^{3}$ HR: http://bd.eionet.europa.eu/activities/Reporting/Article_17/reference_portal
} 


\subsection{Aanpak}

In Hoofdstuk 2 wordt beschreven welke datasets geselecteerd zijn voor de verschillende soortgebiedscombinaties en waarom. In Hoofdstuk 3 wordt beschreven van welke statistiek gebruik kan worden gemaakt voor de analyse van trends. Hoofdstuk 4 vat de beoordelingssystematiek samen en Hoofdstuk 5 behandelt nog enkele discussiepunten en aanbevelingen. 


\section{Selectie van datasets}

\section{$2.1 \quad$ Inleiding}

In dit hoofdstuk wordt beschreven welke datasets we aanbevelen om te gebruiken voor het analyseren van trends per HR-vissoort per Natura 2000-gebied. Eerst wordt een overzicht gepresenteerd van monitoring in zoet en zout water waarin Habitatrichtlijnvissoorten worden aangetroffen ('longlist', §2.2). Binnen deze verschillende datareeksen wordt de meest geschikte monitoring uitgekozen op basis van een aantal selectiecriteria ('shortlist' §2.3, Tabel 6).

\subsection{Overzicht van datasets (longlist)}

\subsubsection{Zoete wateren en overgangswateren}

In de zoete rijkswateren, zoals IJsselmeer, Markermeer, de Randmeren en de grote rivieren, wordt de monitoring van HR-vissoorten en commerciële vissoorten gecoördineerd door Wageningen Marine Research voor Rijkswaterstaat en het ministerie van LNV. Jaarlijks verschijnt een rapport met informatie over trends en ontwikkelingen van commercieel benutte vissoorten, landelijke trends van Habitatrichtlijnvissoorten en Ecologische Kwaliteitsratio's in zoete rijkswateren en overgangswateren (Tien et al., 2019), de gebruikte monitoringsmethoden (Van der Sluis et al., 2019) en de basisdata (online via https://wmropendata.wur.nl/site/zoetwatervis/). Voornamelijk deze data worden in dit rapport gebruikt.

In de overige wateren, inclusief kleinere wateren zoals polders en beken, vindt monitoring door verschillende partijen plaats. De landelijke database NDFF (Nationale Databank Flora en Fauna; https://www.ndff.nl/), gedeeltelijk gefinancierd door het ministerie van LNV, brengt gegevens bijeen die zijn verzameld door waterschappen en gemeentes, al dan niet uitgevoerd door onderzoeksbureaus zoals Bureau Waardenburg, ATKB en Altenburg \& Wymenga, en andere organisaties zoals Stichting RAVON, Sportvisserij Nederland (https://www.vangstenregistratie. $\mathrm{nl} /$ ) en door individuele vrijwilligers (bv. via https://waarneming. $\mathrm{nl} /$ ). Opvragen van gegevens bij NDFF kan eenmalig of met een abonnement. De NDFF data worden in dit rapport niet gebruikt, omdat ze vooral kleinere wateren betreffen.

Niet alle dataseries zijn in de NDFF opgeslagen, zoals monitoring door hengelsportverenigingen. Wageningen Marine Research verzamelt ook gegevens in sommige kleine wateren voor bepaalde projecten, zoals van de rivierprik in de Drentse Aa (Tabel 5). Deze data worden ook niet in dit rapport gebruikt.

\subsubsection{Zoute wateren}

In het algemeen worden zoutwatergegevens niet gebruikt voor de beoordeling van Natura 2000gebieden. Er zijn namelijk nauwelijks data van de betreffende soorten (migrerende vissoorten) beschikbaar uit de monitoring op zee en daarom kunnen migrerende vissoorten het best bij intrekpunten worden gemeten, zoals bv. bij de sluizen tussen de Waddenzee en het IJsselmeer. Ook de EC vraagt (om deze reden) bij de HR-rapportage niet om informatie over deze vissoorten op zee. Toch geven we hier een overzicht van zoutwatergegevens, om te toetsen of deze werkwijze terecht is, of dat er toch waardevolle gegevens beschikbaar zijn. 
Monitoring van de zoute wateren vindt plaats door verschillende partijen. Jaarlijks worden in internationaal verband op de Noordzee, Waddenzee en Westerschelde diverse surveys uitgevoerd door Wageningen Marine Research, zoals de International Bottom Trawl Survey (IBTS: hele Noordzee), de Beam Trawl Survey (BTS: hele Noordzee), de Sole Net Survey (SNS: kustgebieden) en de Demersal Fish Survey (DFS: kustgebieden). Deze surveys vormen onderdeel van de Wettelijke Onderzoekstaken (WOt). Het koninklijke NIOZ (Nederlands Instituut voor Onderzoek der Zee) voert vanaf 1960 gedurende een groot deel van het jaar dagelijkse metingen uit met een fuik (www.waddenzeevismonitor.nl). Een overzicht van beschikbare data van alle monitoring is weergeven in Tabel 5. Zoutwaterdata zijn beschikbaar maar worden alleen gebruikt als waarnemingen van de doelsoorten aanwezig zijn. De DFS data en NIOZ data lijken voor bv. fint interessante data te bevatten. 
Tabel 5. Longlist van databases met gegevens over HR-vissoorten in zoet en zout water. WMR = Wageningen Marine Research. NIOZ=Nederlands Instituut voor Onderzoek der Zee. RWS = Rijkswaterstaat, ATKB = ATKB Adviesbureau voor bodem en ecologie.

\begin{tabular}{|c|c|c|c|c|c|c|}
\hline Data- houder & Programma & Code & Toelichting & $\begin{array}{l}\text { Type } \\
\text { tuig }\end{array}$ & $\begin{array}{l}\text { Geografisch } \\
\text { geschikt voor } \\
1 \text { of meerdere } \\
\text { soort- } \\
\text { gebieds- } \\
\text { combinatie(s) }\end{array}$ & $\begin{array}{l}\text { Data beschikbaar } \\
\text { bij WMR }\end{array}$ \\
\hline & Zoete rijkswateren & & & & & \\
\hline WMR & $\begin{array}{l}\text { Open water } \\
\text { vismonitoring IJssel- } \\
\text { en Markermeer met } \\
\text { actieve vistuigen }\end{array}$ & FYMA & $\begin{array}{l}\text { Actieve monitoring open water IJsselmeer en Markermeer (kuil 1966- } \\
2012 \text { (en sinds } 1989 \text { gestandaardiseerd), opgevolgd door boomkor } \\
\text { sinds 2013; daarnaast elektrostramienkor sinds 1989). }\end{array}$ & Actief & ja & ja \\
\hline WMR & $\begin{array}{l}\text { Oever vismonitoring } \\
\text { IJssel- en } \\
\text { Markermeer met } \\
\text { actieve vistuigen }\end{array}$ & FYOE & $\begin{array}{l}\text { Actieve monitoring (elektroschepnet en zegen) oevers IJsselmeer en } \\
\text { Markermeer; jaarlijks sinds } 2007 .\end{array}$ & Actief & ja & ja \\
\hline WMR & $\begin{array}{l}\text { Monitoring Zeldzame } \\
\text { vis IJssel- en } \\
\text { Markermeer op basis } \\
\text { van fuikregistraties. }\end{array}$ & $\mathrm{ZZ}$ & $\begin{array}{l}\text { Passieve monitoring (fuiken) zeldzame vis IJsselmeer en Markermeer; } \\
\text { jaarlijks, sinds } 2005 \text { gestandaardiseerd. Gestopt in september } 2013 \text {. }\end{array}$ & Passief & ja & ja \\
\hline WMR & $\begin{array}{l}\text { Vismonitoring in } \\
\text { IJssel- en } \\
\text { Markermeer met } \\
\text { kieuwnetten }\end{array}$ & FYSW & $\begin{array}{l}\text { Passieve monitoring met staand want in IJsselmeer en Markermeer. } \\
\text { Jaarlijks vanaf } 2014 .\end{array}$ & Passief & ja & ja \\
\hline WMR & $\begin{array}{l}\text { Diadrome vis } \\
\text { Kornwerderzand } \\
\text { Waddenzee op basis } \\
\text { van fuikregistraties }\end{array}$ & DIADROOM & $\begin{array}{l}\text { Passieve monitoring (fuiken) diadrome vis bij Kornwerderzand (in de } \\
\text { Waddenzee); jaarlijks sinds } 2001 .\end{array}$ & Passief & ja & ja \\
\hline WMR & $\begin{array}{l}\text { Vismonitoring grote } \\
\text { rivieren met actieve } \\
\text { vistuigen }\end{array}$ & FGRA & $\begin{array}{l}\text { Actieve monitoring (elektroschepnet, incidenteel vanaf 1992; boomkor, } \\
\text { vanaf 1992) grote rivieren en delta; jaarlijks sinds } 1997 .\end{array}$ & Actief & ja & ja \\
\hline WMR & $\begin{array}{l}\text { Diadrome vis } \\
\text { monitoring zoete } \\
\text { rijkswateren op basis } \\
\text { van fuikregistraties }\end{array}$ & FDIA & $\begin{array}{l}\text { Passieve monitoring (fuiken) diadrome vis monitoring zoete wateren; } \\
\text { jaarlijks in het najaar sinds } 2012 \text {, sinds } 2015 \text { ook in het voorjaar. }\end{array}$ & Passief & ja & ja \\
\hline WMR & $\begin{array}{l}\text { Vismonitoring zoete } \\
\text { rijkswateren op basis } \\
\text { van vangstregistratie } \\
\text { aalvissers }\end{array}$ & FGRF & $\begin{array}{l}\text { Passieve monitoring (vangstregistratie van aalvissers, vanaf } 1981 \\
\text { kleinschalig niet gestandaardiseerd) grote rivieren, IJssel- en } \\
\text { Markermeer en Delta; in gestandaardiseerde vorm jaarlijks sinds } 1993 . \\
\text { Het aantal locaties is van } 33 \text { teruggelopen naar } 11 \text { in } 2013 \text {. Vanaf } 2014 \\
\text { zijn nog slechts van } 2 \text { locaties de vangsten geregistreerd: Veerse Meer } \\
\text { (locatienr } 36 \text { ) en buitenzijde Haringvliet (nrs } 34 \text { en 32) }\end{array}$ & Passief & ja & ja \\
\hline
\end{tabular}




\begin{tabular}{|c|c|c|c|c|c|c|}
\hline Data- houder & Programma & Code & Toelichting & $\begin{array}{l}\text { Type } \\
\text { tuig }\end{array}$ & $\begin{array}{l}\text { Geografisch } \\
\text { geschikt voor } \\
1 \text { of meerdere } \\
\text { soort- } \\
\text { gebieds- } \\
\text { combinatie(s) }\end{array}$ & $\begin{array}{l}\text { Data beschikbaar } \\
\text { bij WMR }\end{array}$ \\
\hline WMR & $\begin{array}{l}\text { Vismonitoring grote } \\
\text { rivieren op basis van } \\
\text { zalmsteekregistraties }\end{array}$ & FGRZ & Zalmsteekmonitoring grote rivieren; jaarlijks sinds 1994 & Passief & ja & ja \\
\hline WMR & $\begin{array}{l}\text { Vismonitoring } \\
\text { Randmeren met } \\
\text { actieve vistuigen }\end{array}$ & FRAN & $\begin{array}{l}\text { Actieve monitoring (stort- en wonderkuil en elektro schepnet) } \\
\text { Randmeren; } 3 \text { clusters meren welke ieder eens per drie jaar worden } \\
\text { bemonsterd (sinds 2007). }\end{array}$ & Actief & ja & ja \\
\hline WMR * & $\begin{array}{l}\text { Monitoring vangsten } \\
\text { recreatieve visserij* }\end{array}$ & & $\begin{array}{l}\text { Monitoring vangsten recreatieve visserij; om het jaar sinds } 2010 \text { (Van } \\
\text { der Hammen \& De Graaf, 2013; 2015; 2017). }\end{array}$ & N.v.t. & ja & ja \\
\hline $\begin{array}{l}\text { Association } \\
\text { Saumon-Rhin }\end{array}$ & Iffezheim (F) & Iffezheim & $\begin{array}{l}\text { Voor ver op de Rijn optrekkende soorten: zalm, elft, zeeprik evt als } \\
\text { proxy voor wat door NL trekt (http://www.saumon- } \\
\text { rhin.com/comptages/) }\end{array}$ & Passief & ja & $\begin{array}{l}\text { Ja, te downloaden } \\
\text { via website }\end{array}$ \\
\hline RWS/ATKB & Telemetrie & & Telemetriemonitoring van zalm, zeeforel en paling. & Passief & onbekend & nee \\
\hline $\begin{array}{l}\text { Sportvisserij } \\
\text { Nederland }\end{array}$ & & & Onbekend of er gegevens worden verzameld & & onbekend & nee \\
\hline Provincies & & & Onbekend of er gegevens worden verzameld & & onbekend & nee \\
\hline Gemeentes & & & Onbekend of alle gegevens in NDFF staan & & onbekend & nee \\
\hline \multirow[t]{2}{*}{ Waterschappen } & & & Onbekend of alle gegevens in NDFF staan & & onbekend & nee \\
\hline & $\begin{array}{l}\text { Zoete kleinere } \\
\text { wateren }\end{array}$ & & & & & \\
\hline NDFF & $\begin{array}{l}\text { Nationale databank } \\
\text { Flora en Fauna } \\
\text { (NDFF) }\end{array}$ & NDFF & $\begin{array}{l}\text { De Nationale databank Flora en Fauna (NDFF) omvat gegevens van } \\
\text { monitoring door Stichting RAVON, evenals data van gemeentes, } \\
\text { waterschappen en bv. waarneming.nl }\end{array}$ & $\begin{array}{l}\text { Actief } \\
\text { en } \\
\text { passief }\end{array}$ & ja & nee \\
\hline \multirow[t]{2}{*}{ WMR } & Drentse Aa & & Monitoring rivierprik in Drentse Aa door WMR; om het jaar & Actief & nee & ja \\
\hline & Zoute rijkswateren & & & & & \\
\hline NIOZ & Komfuik NIOZ & NIOZ & $\begin{array}{l}\text { Fuik in de Mokbaai bij Texel die sinds de jaren } 60 \text { dagelijks geleegd } \\
\text { wordt (maart-oktober): www.waddenzeevismonitor.nl }\end{array}$ & Passief & onbekend & $\begin{array}{l}\text { ja, te downloaden } \\
\text { via website }\end{array}$ \\
\hline WMR & $\begin{array}{l}\text { Boomkorsurvey } \\
\text { (BTS) }\end{array}$ & FRISBE/DATRAS & www.bodc.ac.uk/data/information_and_inventories/edmed/report/4801/ & Actief & ja & ja \\
\hline WMR & $\begin{array}{l}\text { International Bottom } \\
\text { Trawl Survey (IBTS) }\end{array}$ & FRISBE/DATRAS & www.bodc.ac.uk/data/information_and_inventories/edmed/report/4798/ & Actief & ja & ja \\
\hline WMR & $\begin{array}{l}\text { Demersal Young Fish } \\
\text { Survey (DFS) }\end{array}$ & FRISBE/DATRAS & www.bodc.ac.uk/data/information_and_inventories/edmed/report/4800/ & Actief & ja & ja \\
\hline WMR & $\begin{array}{l}\text { Bemonstering aan } \\
\text { boord van } \\
\text { commerciële kotters } \\
\text { (demersaal) }\end{array}$ & FRISBE/DATRAS & www.bodc.ac.uk/data/information_and_inventories/edmed/report/4797/ & Actief & ja & ja \\
\hline WMR & $\begin{array}{l}\text { Bemonstering aan } \\
\text { boord van } \\
\text { commerciële kotters } \\
\text { (garnaal) }\end{array}$ & FRISBE/DATRAS & www.bodc.ac.uk/data/information_and_inventories/edmed/report/4795/ & Actief & ja & ja \\
\hline
\end{tabular}

18 van 61 | Wageningen Marine Research rapport c005/20 


\begin{tabular}{|c|c|c|c|c|c|c|}
\hline Data- houder & Programma & Code & Toelichting & $\begin{array}{l}\text { Type } \\
\text { tuig }\end{array}$ & $\begin{array}{l}\text { Geografisch } \\
\text { geschikt voor } \\
1 \text { of meerdere } \\
\text { soort- } \\
\text { gebieds- } \\
\text { combinatie(s) }\end{array}$ & $\begin{array}{l}\text { Data beschikbaar } \\
\text { bij WMR }\end{array}$ \\
\hline WMR & $\begin{array}{l}\text { Bemonstering van } \\
\text { commerciële } \\
\text { staandwantvisserij }\end{array}$ & FRISBE/DATRAS & $\begin{array}{l}\text { Geen metadatarecord; de bemonstering omvat het uitzoeken en } \\
\text { doormeten van vangsten op de kustgebonden staandwantvisserij. }\end{array}$ & Actief & ja & ja \\
\hline WMR & $\begin{array}{l}\text { Sole Net Survey } \\
\text { (SNS) }\end{array}$ & FRISBE/DATRAS & www.bodc.ac.uk/data/information_and_inventories/edmed/report/4799/ & Actief & ja & ja \\
\hline WMR & $\begin{array}{l}\text { Westerschelde } \\
\text { Ankerkuilvisserij }\end{array}$ & FRISBE/DATRAS & $\begin{array}{l}\text { www.bodc.ac.uk/data/information_and_inventories/edmed/report/5826/ } \\
\text { (2007-nu) }\end{array}$ & Actief & ja & ja \\
\hline WMR & $\begin{array}{l}\text { Eems-Dollard } \\
\text { Ankerkuilvisserij }\end{array}$ & FRISBE/DATRAS & Geen metadatarecord, bemonstering uitgevoerd door Bioconsult; & Actief & ja & ja \\
\hline WMR & $\begin{array}{l}\text { Bemonstering PMR } \\
\text { Maasvlakte }\end{array}$ & FRISBE/DATRAS & www.bodc.ac.uk/data/information_and_inventories/edmed/report/5834/ & Actief & ja & ja \\
\hline
\end{tabular}




\subsection{Selectie van dataseries (shortlist)}

Per Natura 2000-gebied zijn uit Tabel 5 per vissoort-gebiedscombinatie dataseries door een specialist (visecoloog E. Winter, WMR) geselecteerd op basis van selectiecriteria die zijn samengevat in Tabel 6 en die uitgebreid worden behandeld in onderstaande paragrafen. De criteria dienen om tot een of meerdere geschikte dataseries per vissoort per gebied te komen. De geselecteerde datasets zijn weergegeven in Tabel 8. De dataseries waartoe WMR geen toegang heeft zijn buiten beschouwing gelaten (zie Tabel 5, kolom 'datahouder'). Bijlage 3 bevat ter illustratie kaarten van de Natura 2000-gebieden en de dataseries.

Tabel 6. Criteria voor selectie van geschikte dataseries voor statistische analyses van trends binnen de beoordelingsperiode en voor aanvullende expert judgement voor een langere periode, per vissoort per Natura 2000-gebied. De criteria worden toegelicht in hoofdstuk 2.3.

\begin{tabular}{|c|c|c|}
\hline $\mathrm{Nr}$ & Criterium & \\
\hline 1 & $\begin{array}{l}\text { Liggen er geschikte meetpunten in het Natura } \\
\text { 2000-gebied? }\end{array}$ & $\begin{array}{l}\text { Ja: dataserie geschikt } \\
\text { Nee: dataserie alleen geschikt indien relatie tussen het } \\
\text { Natura } 2000 \text {-gebied en het meetpunt duidelijk is (zie tekst } \\
\text { in rapport). }\end{array}$ \\
\hline 2 & $\begin{array}{l}\text { Liggen meetpunten in zoet water? (voor } \\
\text { migrerende soorten) }\end{array}$ & $\begin{array}{l}\text { Ja: dataserie geschikt } \\
\text { Nee: indien meetpunten in zout water liggen moeten data } \\
\text { worden gecontroleerd op geschiktheid }\end{array}$ \\
\hline $3 a$ & $\begin{array}{l}\text { Evaluatieperiode: dekt dataserie het volledige } \\
\text { tijdvak tussen jaar van aanwijzing Natura 2000- } \\
\text { gebied en evaluatiemoment? }\end{array}$ & $\begin{array}{l}\text { Ja: dataserie geschikt } \\
\text { Nee: dataserie mogelijk geschikt, ter beoordeling aan } \\
\text { expert }\end{array}$ \\
\hline $3 b$ & $\begin{array}{l}\text { Lange termijn: Dekt de dataserie een langere } \\
\text { periode voorafgaand aan het tijdvak tussen jaar } \\
\text { van aanwijzing Natura 2000-gebied en } \\
\text { evaluatiemoment? }\end{array}$ & $\begin{array}{l}\text { Ja: dataserie geschikt voor aanvullende interpretatie } \\
\text { d.m.v. expert judgement (zie tekst in rapport) } \\
\text { Nee: data niet geschikt voor aanvullende interpretatie. }\end{array}$ \\
\hline 4 & Loopt dataserie door in toekomst? & $\begin{array}{l}\text { Ja: dataserie geschikt } \\
\text { Nee: dataserie mogelijk minder geschikt (zie tekst in } \\
\text { rapport) }\end{array}$ \\
\hline 5 & $\begin{array}{l}\text { Is lengte serie > } 3 \text { jaar? (Vanaf jaar van aanwijzing } \\
\text { Natura 2000-gebied }\end{array}$ & $\begin{array}{l}\text { Ja: dataserie geschikt } \\
\text { Nee: dataserie mogelijk in de toekomst geschikt als hij } \\
\text { langer is }\end{array}$ \\
\hline 6 & Monitoring in juiste seizoen? (diadrome vissen) & $\begin{array}{l}\text { Ja: dataserie geschikt } \\
\text { Nee: dataserie niet geschikt }\end{array}$ \\
\hline 7 & Is vismethode (actief/passief) passend bij soort? & $\begin{array}{l}\text { Ja: dataserie geschikt } \\
\text { Nee: dataserie meestal ongeschikt (zie tekst in rapport) }\end{array}$ \\
\hline 8 & Is maaswijdte vistuig geschikt? & $\begin{array}{l}\text { Ja: dataserie geschikt } \\
\text { Nee: dataserie ongeschikt }\end{array}$ \\
\hline 9 & Selectie op lengte & $\begin{array}{l}\text { Ja: dataserie geschikt er lengte-data aanwezig zijn en } \\
\text { indien functie gebied verschilt voor juvenielen en adulten } \\
\text { Nee: dataserie minder geschikt als functie gebied verschilt } \\
\text { voor juvenielen en adulten, maar er geen lengte-data zijn. }\end{array}$ \\
\hline
\end{tabular}




\subsubsection{Selectiecriteria}

\section{Criterium 1. Liggen er geschikte meetpunten in het Natura 2000-gebied?}

De voorkeur gaat uit naar meetpunten binnen het betreffende Natura 2000-gebied, of bij een intrekpunt (bv een sluis) op de rand van het gebied. Meetpunten elders uit het stroomgebied (bv. stroomopwaarts) kunnen gebruikt worden als zeker is dat het Natura 2000-gebied een corridorfunctie heeft voor de soort, of dat het als paaigebied dient. Een voorbeeld is zalm in het Haringvliet: zalm paait over de grens in Duitsland, en de belangrijkste migratieroute loopt van het Haringvliet via de Waal naar de Rijn in Duitsland. In dit geval fungeert het Haringvliet als corridor en kunnen de data uit de Waal gebruikt worden als proxy voor het Haringvliet (zalm wordt namelijk niet in het Haringvliet gemonitord).

Als de relatie tussen het Natura 2000-gebied en een bepaald stroomgebied niet duidelijk is, adviseren we de data afkomstig uit dat stroomgebied niet te gebruiken. Voor finten in de Voordelta is het bijvoorbeeld niet duidelijk uit welk gebied ze afkomstig zijn. Ze gebruiken het gebied om te foerageren. In dat geval worden alleen maar data uit de Voordelta zelf gebruikt, omdat niet duidelijk is of er een relatie is tussen het aantal finten in de Voordelta en de Westerschelde, het Haringvliet of de Noordzeekustzone.

Voor zalm geldt dat er slechts 2 representatieve meetpunten zijn voor alle verschillende Natura 2000gebieden samen: bij Lith, voor de benedenstroom van het Natura 2000-gebied Grensmaas, en in de Waal voor de overige Natura 2000-gebieden (Haringvliet, Hollands Diep, Biesbosch, Rijntakken).

Voor fint geldt dat een deel van de populatie in het voorjaar de zoete wateren in trekt (E. Winter, pers. com), maar dat er de rest van het jaar ook veel finten in de kustwateren verblijven. Het is nog niet duidelijk of ze Nederland intrekken om te paaien.

Voor elft geldt dat de gebruikte meetnetten op zich geschikt zijn, maar dat de soort op dit moment in te lage aantallen voorkomt voor een trendanalyse.

\section{Criterium 2. Liggen meetpunten in zoet water?}

Dit criterium geldt alleen voor migrerende HR-soorten (zalm, fint, elft, zeeprik, rivierprik). In het algemeen worden zoutwatergegevens niet gebruikt voor de beoordeling van migrerende HR-vissoorten in Natura 2000-gebieden. In zoet water, of op de overgang van zoet naar zout water, zijn migrerende HR-vissoorten vaak beter te bemonsteren dan op volle zee. Er zijn namelijk nauwelijks data van de betreffende soorten beschikbaar uit de monitoring op zee. Daarom kunnen migrerende vissoorten het best bij intrekpunten worden gemeten, zoals bv. bij de sluizen tussen de Waddenzee en het IJsselmeer.

In estuaria kunnen de aantallen gevangen migrerende vissen nog aanzienlijk zijn, zoals bijvoorbeeld finten in de Eems-Dollard. De voorkeur gaat daarom uit naar data afkomstig van meetpunten in zoet water of op de overgang van zoet naar zout water. Wel bevelen we aan de zoutwaterdata te screenen op aanwezigheid van de doelsoorten.

Voor de soort-gebiedscombinaties Waddenzee-fint en Waddenzee-rivierprik, en Westerschelde-fint, en Westerschelde-rivierprik kunnen de ankerkuildata interessant zijn, omdat doorgaans behoorlijke aantallen van deze soorten worden gevangen met de ankerkuil.

Criterium 3a. Evaluatieperiode: dekt dataserie het volledige tijdvak tussen jaar van aanwijzing Natura 2000-gebied en evaluatiemoment?

De voorkeur gaat uit naar dataseries die de volledige tijdperiode dekken vanaf moment van aanwijzing. De referentiedatum voor het halen van de instandhoudingsdoelstelling is namelijk het moment van aanwijzing van een Natura 2000-gebied (bv. in 2010). In gebieden waar maar eens per 3 
jaar wordt gemonitord (bv 2011, 2014, 2017) kunnen ook jaren net voor het moment van aanwijzing gebruikt worden (bv. 2009). In de statistische analyse wordt alleen gekeken naar de trend over de periode vanaf het jaar van aanwijzing.

Criterium 3b. Lange termijn: Dekt de dataserie een langere periode voorafgaand aan het tijdvak tussen jaar van aanwijzing Natura 2000-gebied en evaluatiemoment?

Voor de interpretatie van trends op korte termijn is het nuttig inzicht in de langere termijnontwikkelingen te hebben. We bevelen daarom aan om ook langere termijn dataseries te selecteren en de data in een grafiek te zetten t.b.v. de interpretatie van de kortere serie.

\section{Criterium 4. Loopt dataserie door in toekomst?}

De voorkeur gaat uit naar toekomstbestendige dataseries. De temporele dekking van de dataseries is weergegeven in Tabel 5. Een aantal dataseries wordt nog niet zo lang verzameld (bv sinds 2012).

\section{Criterium 5. Is lengte serie > 3 jaar? (Vanaf jaar van aanwijzing Natura 2000-gebied)}

Voor trendanalyses is een minimum aantal jaren nodig van ten minste 3 jaren. Bij 2 punten is statistiek niet mogelijk. Meer dan 3 datapunten (bv. 6) is gunstiger. Indien de enig beschikbare dataserie slechts een paar punten kent zal de trend grotendeels op basis van expertkennis moeten worden vastgesteld.

\section{Criterium 6. Monitoring in juiste seizoen?}

De bemonstering van migrerende soorten moet bij voorkeur plaatsvinden tijdens de migratiepiek. Voor een trendanalyse van de diadrome soorten zijn de maanden relevant waarin de adulten hoofdzakelijk migreren (Tabel 7). Welke maanden dit zijn is afhankelijk van de soortspecifieke biologie. Een aanname in deze selectiemethode is dat in de migratiemaanden voornamelijk migrerende adulten gevangen worden in de fuiken. In de regel wordt een locatie alleen meegenomen in de analyse als alle migratiemaanden consistent door de jaren heen bemonsterd zijn.

\section{Criterium 7. Is vismethode (actief/passief) passend bij soort?}

Voor diadrome soorten -soorten die tussen zout en zoet water migreren- (elft, fint, houting, zeeprik, rivierprik, zalm) zijn programma's geschikt die gebruik maken van passieve vistuigen (staand want, verschillende fuiken, zalmsteken) (voor meer informatie zie Tien et al. 2019). Voor niet-migrerende soorten geldt dat actieve vistuigen (boomkor, elektroschepnet) het meest geschikt zijn, omdat deze soorten (bittervoorn, grote en kleine modderkruiper, rivierdonderpad) veel tijd doorbrengen op een vaste locatie (Tabel 7). Voor fint worden aanvullend ook de gegevens uit de actieve monitoring onderzocht op hun geschiktheid (DFS), omdat er vangsten met die methode voor de soort zijn.

\section{Criterium 8. Is maaswijdte vistuig geschikt?}

Per vissoort verschilt de meest geschikte maaswijdte. Zalmen zullen netten met kleine maaswijdte vermijden, en kunnen het best met een net met grote mazen gevangen worden. Kleine vissoorten zoals de kleine modderkruiper en rivierdonderpad zullen juist door grote mazen glippen en kunnen alleen met een fijnmazig net gevangen worden. In het algemeen zullen vismethodes die zijn opgezet voor het vangen van specifieke HR-vissoorten de beste resultaten opleveren (methode passend bij de soort). In Tabel 7 is zeer globaal aangegeven welke maaswijdte geschikt is per vissoort. 
Tabel 7. Geselecteerde maanden en vistuig per HR-vissoort.

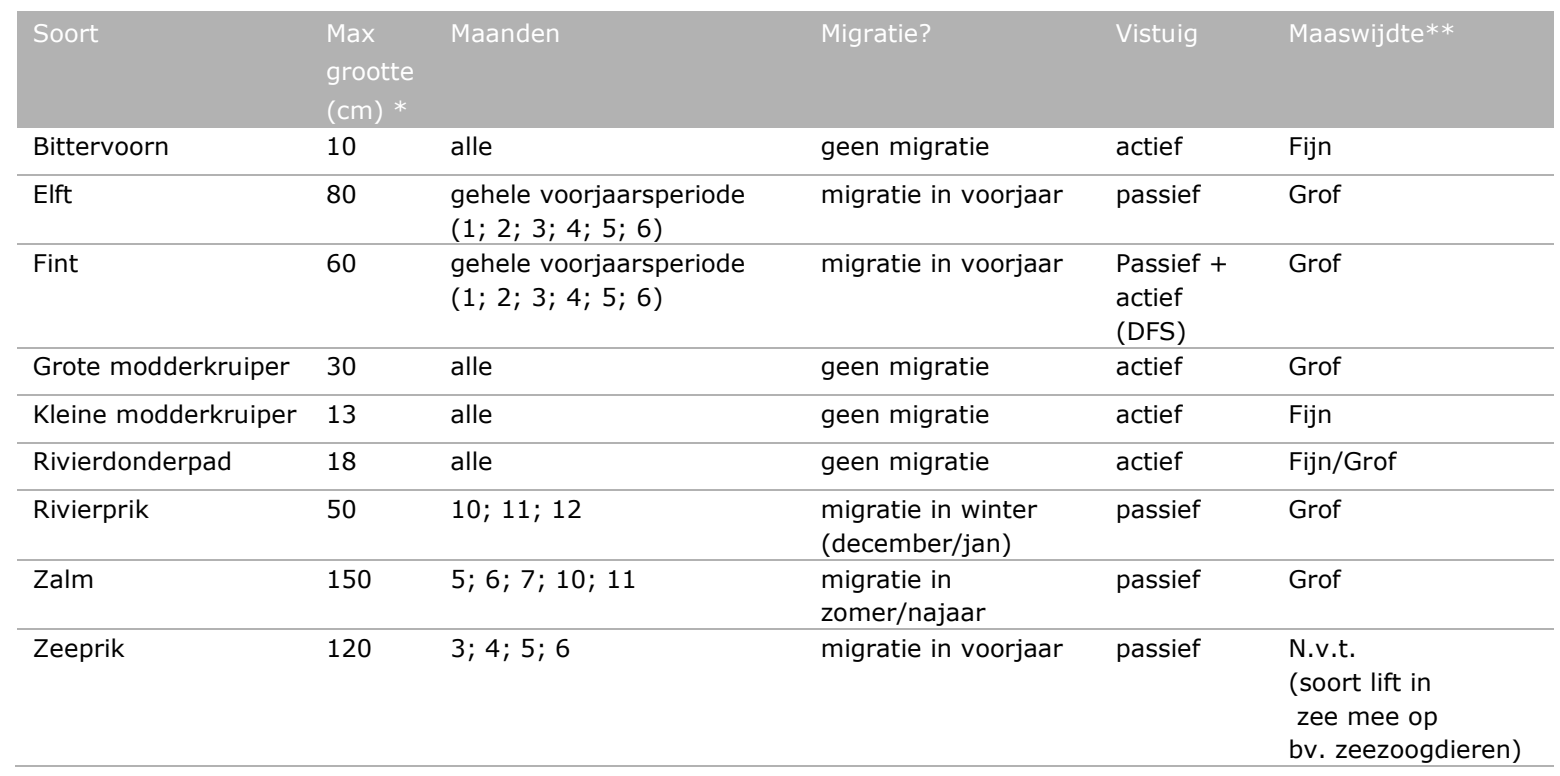

*Bron: Sportvisserij Nederland

**Maaswijdte per survey staat beschreven in Van der Sluis et al. (2019).

\section{Criterium 9. Selectie op lengte in relatie tot de functie van gebied voor de soort}

Als de functie van het gebied duidelijk is voor de soort, bv. als een gebied als opgroeigebied dient voor juvenielen, of voornamelijk als paaigebied dient voor volwassenen, dan gaat de voorkeur uit naar data waarbinnen lengte-klassen te onderscheiden zijn. Zo kunnen aantallen adulten van juvenielen onderscheiden worden. Een voorbeeld is de fuikenmonitoring bij de Haringvlietsluizen. Hier worden zowel adulte als juveniele fint gevangen, waarbij volwassen individuen waarschijnlijk deelnemen aan de paaitrek, en de juvenielen het gebied als opgroei- en foerageergebied gebruiken. Als volwassen fint worden individuen $>30 \mathrm{~cm}$ beschouwd, voor elft gaat het om individuen $>45 \mathrm{~cm}$. Er zijn ook soorten waarvoor lengteselectie niet mogelijk is zoals zeeprik en rivierprik, omdat alleen volwassen individuen zijn gevangen (kleine prikken zwemmen door mazen van de fuik heen). Andere soorten zoals rivierdonderpad migreren niet. Lengte-selectie wordt voor deze soorten niet toegepast aangezien het gebied wordt gebruikt door alle levensstadia. Een overzicht van de functie per gebied staat in Tabel 8. 


\subsubsection{Geselecteerde data}

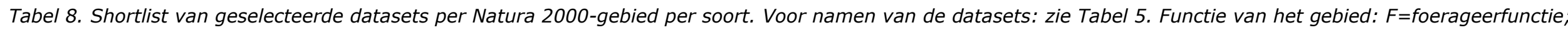
$O=$ opgroeigebied ( $1^{e}$ jaar); $P=$ paaigebied; $C=$ corridor; $L=$ gehele levenscyclus. Afwezigheid van data wordt aangeduid met Not Available (NA).

\begin{tabular}{|c|c|c|c|c|c|c|c|c|}
\hline Natura 2000-gebied & $\begin{array}{l}\text { Jaar van } \\
\text { aanwijzing }\end{array}$ & Soort & Functie & Dataset naam & Dataset gebied & Actief of passief & Startjaar & Eindjaar \\
\hline \multirow[t]{8}{*}{ Biesbosch } & 2013 & Elft & C & IFFEZHEIM & Iffezheim & Passief & 2000 & doorlopend \\
\hline & & Fint & $P, O$ & NA & NA & NA & NA & NA \\
\hline & & Grote modderkruiper & L & FGRA & Noordwaard & Actief & 1997 & doorlopend \\
\hline & & Kleine modderkruiper & L & FGRA & Noordwaard & Actief & 1997 & doorlopend \\
\hline & & Rivierdonderpad & L & FGRA & Noordwaard & Actief & 1997 & doorlopend \\
\hline & & Rivierprik & $\mathrm{C},(\mathrm{O})$ & NA & NA & NA & NA & NA \\
\hline & & Zalm & C & FGRZ & Waal & Passief & 1994 & doorlopend \\
\hline & & Zeeprik & C & IFFEZHEIM & Iffezheim & Passief & 2000 & doorlopend \\
\hline \multirow[t]{3}{*}{ Grensmaas } & 2013 & Rivierdonderpad & L & FGRA & Grensmaas & Actief & 1997 & doorlopend \\
\hline & & Rivierprik & $\mathrm{C}, \mathrm{P}, \mathrm{O}$ & NA & NA & NA & NA & NA \\
\hline & & Zalm & C & FGRZ & Lith* & Passief & 1994 & doorlopend \\
\hline \multirow[t]{7}{*}{ Haringvliet } & 2015 & Bittervoorn & NA & NA & NA & NA & NA & NA \\
\hline & & Elft & $C_{1}(0)$ & FDIA & Haringvliet & Passief & 2012 & doorlopend \\
\hline & & Fint & $C,(O, F)$ & FDIA & Haringvliet & Passief & 2012 & doorlopend \\
\hline & & Rivierdonderpad & L & FGRA & Haringvliet & Actief & 1997 & doorlopend \\
\hline & & Rivierprik & $C,(F)$ & FDIA & Haringvliet & Passief & 2012 & doorlopend \\
\hline & & Zalm & C & FGRZ & Waal & Passief & 1994 & doorlopend \\
\hline & & Zeeprik & C & FDIA & Haringvliet & Passief & 2012 & doorlopend \\
\hline \multirow[t]{4}{*}{ Hollands Diep } & 2013 & Elft & $C_{1}(\mathrm{O}$ & FDIA & Haringvliet & Passief & 2012 & doorlopend \\
\hline & & Fint & $C,(0)$ & FDIA & Haringvliet & Passief & 2012 & doorlopend \\
\hline & & Rivierprik & $C,(F)$ & FDIA & Haringvliet & Passief & 2012 & doorlopend \\
\hline & & Zalm & C & FDIA & Haringvliet & Passief & 2012 & doorlopend \\
\hline
\end{tabular}




\begin{tabular}{|c|c|c|c|c|c|c|c|c|}
\hline Natura 2000-gebied & $\begin{array}{l}\text { Jaar van } \\
\text { aanwijzing }\end{array}$ & Soort & Functie & Dataset naam & Dataset gebied & Actief of passief & Startjaar & Eindjaar \\
\hline & & & & FGRZ & Waal & Passief & 1994 & doorlopend \\
\hline & & Zeeprik & C & FDIA & Haringvliet & Passief & 2012 & doorlopend \\
\hline \multirow[t]{2}{*}{ IJsselmeer } & 2010 & Rivierdonderpad & L & FYMA & IJsselmeer & Actief & 1989\# & doorlopend \\
\hline & & & & FYOE & IJsselmeer & Actief & 2007 & doorlopend \\
\hline \multirow{2}{*}{$\begin{array}{l}\text { Markermeer } \\
\& \text { IJmeer }\end{array}$} & 2010 & Rivierdonderpad & L & FYMA & Markermeer & Actief & 1989\# & doorlopend \\
\hline & & & & FYOE & Markermeer & Actief & 2007 & doorlopend \\
\hline \multirow[t]{8}{*}{ Noordzeekustzone } & 2009 & Fint & $\mathrm{F}, \mathrm{O},(\mathrm{C})$ & DFS & Noordzeekustzone & Actief & 1969 & doorlopend \\
\hline & & & & DIADROOM & Waddenzee & Passief & 2001 & doorlopend \\
\hline & & & & NIOZ fuik & Waddenzee & Passief & 1960 & doorlopend \\
\hline & & Rivierprik & $F,(C)$ & DFS & Noordzeekustzone & Actief & 1969 & doorlopend \\
\hline & & & & DIADROOM & Waddenzee & Passief & 2001 & doorlopend \\
\hline & & & & NIOZ FUIK & Waddenzee & Passief & 1960 & doorlopend \\
\hline & & Zeeprik & $\mathrm{F},(\mathrm{C})$ & DIADROOM & Waddenzee & Passief & 2001 & doorlopend \\
\hline & & & & NIOZ FUIK & Waddenzee & Passief & 1960 & doorlopend \\
\hline \multirow[t]{4}{*}{ Rijntakken } & 2014 & Elft & $\mathrm{C}$ & FDIA & Rijn & Passief & 2012 & doorlopend \\
\hline & & Rivierprik & $P, C, O$ & NA & NA & NA & NA & NA \\
\hline & & Zalm & $\mathrm{C}$ & FGRZ & Waal, IJssel, Lek, Nederrijn & Passief & 1994 & doorlopend \\
\hline & & Zeeprik & C & FDIA & Rijn & Passief & 2012 & doorlopend \\
\hline \multirow[t]{2}{*}{ Veluwerandmeren } & 2010 & Kleine modderkruiper & L & FRAN & Veluwerandmeren & Actief & $\begin{array}{l}2007 \\
\text { (3-jaarlijks } \\
\text { per cluster } \\
\text { meren) }\end{array}$ & doorlopend \\
\hline & & Rivierdonderpad & L & FRAN & Veluwerandmeren & Actief & $\begin{array}{l}2007 \\
\text { (3-jaarlijks } \\
\text { per cluster } \\
\text { meren) }\end{array}$ & doorlopend \\
\hline \multirow[t]{3}{*}{ Vlakte van de Raan } & 2010 & Fint & $\mathrm{F}, \mathrm{C}$ & DFS & Vlakte van de Raan & Actief & 1969 & doorlopend \\
\hline & & Rivierprik & F, C & DFS & Vlakte van de Raan & Actief & 1969 & doorlopend \\
\hline & & Zeeprik & $\mathrm{F}$ & NA & NA & NA & NA & NA \\
\hline \multirow[t]{3}{*}{ Voordelta } & 2008 & Elft & F, C & DFS & Voordelta & Actief & 1969 & doorlopend \\
\hline & & & & FGRF & Haringvliet est*** & Passief & 1993 & 2014 \\
\hline & & Fint & $\mathrm{F}, \mathrm{C}, \mathrm{O}$ & DFS & Voordelta & Actief & 1969 & doorlopend \\
\hline
\end{tabular}




\begin{tabular}{|c|c|c|c|c|c|c|c|c|}
\hline Natura 2000-gebied & $\begin{array}{l}\text { Jaar van } \\
\text { aanwijzing }\end{array}$ & Soort & Functie & Dataset naam & Dataset gebied & Actief of passief & Startjaar & Eindjaar \\
\hline & & & & FGRF & Haringvliet est*** & Passief & 1993 & $2014 * *$ \\
\hline & & Rivierprik & $F, C$ & DFS & Voordelta & Actief & 1969 & doorlopend \\
\hline & & & & FGRF & Haringvliet est*** & Passief & 1993 & $2014 * *$ \\
\hline & & Zeeprik & $\mathrm{F}, \mathrm{C}$ & FGRF & Haringvliet est*** & Passief & 1993 & $2014 * *$ \\
\hline \multirow[t]{10}{*}{ Waddenzee } & 2008 & Fint & $\mathrm{F}, \mathrm{C}, \mathrm{O}$ & DFS & Waddenzee & Actief & 1969 & doorlopend \\
\hline & & & & DIADROOM & Waddenzee & Passief & 2001 & doorlopend \\
\hline & & & & NIOZ FUIK & Waddenzee & Passief & 1960 & doorlopend \\
\hline & & Rivierprik & $\mathrm{F}, \mathrm{C}$ & DFS & Waddenzee & Actief & 1969 & doorlopend \\
\hline & & & & NIOZ FUIK & Waddenzee & Passief & 1960 & doorlopend \\
\hline & & & & DIADROOM & Waddenzee & Passief & 2001 & doorlopend \\
\hline & & & & FDIA & IJsselmeer & Passief & 2012 & doorlopend \\
\hline & & Zeeprik & $\mathrm{F}, \mathrm{C}$ & DIADROOM & Waddenzee & Passief & 2001 & doorlopend \\
\hline & & & & NIOZ FUIK & Waddenzee & Passief & 1960 & doorlopend \\
\hline & & & & FDIA & IJsselmeer & Passief & 2012 & doorlopend \\
\hline \multirow[t]{3}{*}{ Westerschelde \& Saeftinghe } & 2010 & Fint & $\mathrm{F}, \mathrm{C}, \mathrm{O}$ & Ankerkuil & Westerschelde & Passief & 2007 & doorlopend \\
\hline & & Rivierprik & $\mathrm{F}, \mathrm{C}$ & Ankerkuil & Westerschelde & Passief & 2007 & doorlopend \\
\hline & & Zeeprik & $\mathrm{F}, \mathrm{C}$ & Ankerkuil & Westerschelde & Passief & 2007 & doorlopend \\
\hline \multirow[t]{3}{*}{ Zwarte Meer } & 2010 & Grote modderkruiper & L & FRAN & NA & NA & NA & NA \\
\hline & & Kleine modderkruiper & L & FRAN & NA & NA & NA & NA \\
\hline & & Rivierdonderpad & L & FRAN & NA & NA & NA & NA \\
\hline
\end{tabular}

\# Elektrostramien-kor; kuil 1966-2012; boomkor sinds 2013

* Trendbreuk, fuik in vispassage is er niet meer

** Geëindigd in 2014, behalve 2 locaties: Veerse Meer en buitenzijde Haringvliet Noord en Zuid

*** Trendbreuk door kier in Haringvliet 


\section{Statistiek en evaluatie}

\subsection{Inleiding}

In dit hoofdstuk wordt beschreven welke statistische methoden worden aanbevolen om populatietrends te analyseren per vissoort per Natura 2000-gebied, afhankelijk van de kwaliteit van de beschikbare data. In $§ 3.3$ zijn 2 voorbeelden van soort-gebiedscombinaties uitgewerkt en statistisch getoetst.

\subsubsection{Achtergrond: protocollen voor statistische analyse}

Binnen de statistiek is een groot aantal technieken beschikbaar om data te analyseren. Welke techniek het meest geschikt is voor het beantwoorden van een bepaalde vraagstelling hangt af van het type data, de beperkingen van de data, de ruimtelijke en temporele verspreiding en afhankelijkheden van datapunten, de verdeling van de aantallen binnen een datareeks, etc. Typische kenmerken van de hier gebruikte vangstdata zijn dat HR-vissoorten weinig worden aangetroffen, omdat ze zeldzaam zijn. Dit resulteert in veel nul-waarnemingen. Ook zijn data afkomstig van verschillende (indien mogelijk) gecombineerde monitoringsseries. De uitkomsten van de analyses moeten iets zeggen over afname, gelijke trend of toenemende trend van een bepaalde HR-vissoort in een Natura 2000-gebied, zodat het instandhoudingsdoel uit het aanwijzingsbesluit getoetst kan worden.

Om ondersteuning te bieden aan ecologische data-analyse in het algemeen is door Zuur \& Ieno (2016) en Zuur et al. (2010) een tweetal protocollen opgesteld. Het doel van die protocollen is om op een gestructureerde wijze analyses uit te voeren, met een goed begrip van de data, met het juiste statistische model en met duidelijk beschreven resultaten. Beide protocollen worden daarom kort weergegeven. Het eerste protocol beschrijft 10 stappen voor het uitvoeren en presenteren van resultaten van regressie-analyses (Zuur \& Ieno, 2016; Box 1). Het tweede protocol gaat specifiek over data-exploratie om veel voorkomende statistische problemen te vermijden (Zuur \& Ieno, 2010; Box 2). Voor meer informatie over de stappen beschreven in dit rapport verwijzen we naar beide publicaties.

Box 1. Protocol voor statistische analyse van data en presentatie van resultaten in wetenschappelijke publicaties (Zuur \& Ieno, 2016).

1. Stel de juiste vraag

2. Visualiseer het experimentele design (de datapunten in de ruimte)

3. Voer data exploratie uit (zie box 2)

4. Identificeer de afhankelijkheden binnen de data

5. Presenteer het statistische model

6. Fit het model

7. Valideer het model

8. Interpreteer en presenteer de numerieke output van het model

9. Creëer een visuele representatie van het model.

10. Simuleer vanaf het model.

Box 2. Protocol voor data-exploratie (Zuur et al., 2010).

1. Formuleer biologische hypothese, voer experiment uit, verzamel data

2. Data-exploratie: controleer:

- Uitschieters X en Y: Boxplot \& Cleveland dotplot

- Homogeniteit $Y$ : Conditional boxplot

- Normaliteit Y: Histogram of QQ plot 
- $\quad$ Nullen Y: Frequency plot of corrgram

- Collineariteit X: VIF \& scatterplots correlations \& PCA

- Relaties X en Y: (multi-panel) scatterplots, condional boxplots

- Interacties: Coplots

- Onafhankelijkheid Y: ACF \& variogram, plot Y vs tijd/ruimte

3. Pas statistisch model toe

De stappen 1-8 uit Box 1 worden hierna verder uitgewerkt. De stappen in Box 2 zijn technische aspecten waarmee een statisticus bij analyse van data altijd rekening dient te houden, maar die in dit rapport verder niet aan bod komen en hier ter informatie genoemd worden.

\subsection{Aanpak statistiek}

Het protocol van Zuur \& Ieno (2016) is gevolgd om de data van de soort-gebiedscombinaties en de te gebruiken statistiek (stappen 1-5) te beschrijven. Voor meer informatie over onderstaande stappen verwijzen we naar Zuur \& Ieno (2016). Een daadwerkelijke analyse is vervolgens aan de hand van twee voorbeelden van soort-gebiedscombinaties uitgevoerd (§3.3).

\subsubsection{Stap 1. Stellen van de juiste vraag}

De vraag per soortgebiedscombinatie in dit rapport luidt: wat is de trend van de populatie van een bepaalde HR-vissoort in een bepaald Natura 2000-gebied vanaf het jaar van aanwijzing tot het jaar van evaluatie van het beheerplan?

\subsubsection{Stap 2. Visualiseer het experimentele design (de datapunten in de ruimte)}

Per Natura 2000-gebied worden de gebruikte datapunten voor de statistische analyse geplot op een kaart (Bijlage 3).

\subsubsection{Stap 3. Voer data-exploratie uit}

Per soort-gebiedscombinatie moet per type monitoring en vistuig een grafiek gemaakt worden van de gehele tijdserie, met daarin het jaar van aanwijzing van het Natura 2000-gebied duidelijk aangegeven. De statistische analyse wordt alleen uitgevoerd over het gedeelte van de dataset vanaf het jaar van aanwijzing van het Natura 2000-gebied.

De basisgegevens komen uit verschillende meetprogramma's die meestal over verschillende perioden zijn uitgevoerd, vaak met verschillende vangtuigen die ook nog eens met verschillende inspanning zijn ingezet. Daar komt bij dat de meetpunten ("stations") niet elk jaar op precies dezelfde plek zijn bemonsterd. Hier kunnen verschillende oorzaken aan ten grondslag liggen. De bemonstering is in dat geval wel uitgevoerd binnen een redelijke afstand van de oorspronkelijke locatie (M. Roos, RWS, pers. com.)

Door de hierboven genoemde eigenschappen van de meetprogramma's in combinatie met natuurlijke variatie in de visaantallen op een meetpunt variëren de aantallen voor alle soorten sterk tussen vangsten binnen hetzelfde Natura 2000-gebied. Regelmatig worden tientallen of honderden vissen gevangen op een station waar in andere jaren geen of maar enkele exemplaren worden gevangen. In een ander jaar kunnen dergelijke hoge aantallen weer op een ander station gevonden worden. Ook de vangstresultaten per vangtuig variëren enorm, zoals bijvoorbeeld voor de fint in de Waddenzee, waar de vangstkans met de ankerkuil boven de $60 \%$ is, maar met boomkor en fuik minder dan $5 \%$. Omdat de vangstkansen variëren per soort en per tuig, is niet één algemene trendanalyse toe te passen voor

\footnotetext{
${ }^{4}$ Auteur: Leo Soldaat, CBS
} 
alle soort-gebiedscombinaties. Daar komt bij dat veel tijdreeksen nog erg kort zijn. Verwacht mag worden dat met het langer worden van de reeksen de kans op het vinden van een trend groter wordt. Daarom wordt per soort-gebiedscombinatie de beste trendmethode bepaald.

\subsubsection{Stap 4. Identificeer de afhankelijkheden binnen de data}

In het algemeen zijn ecologische observaties van de responsvariabele vaak temporeel of ruimtelijk gecorreleerd. Met geavanceerde statistische technieken kan hiervoor worden gecorrigeerd. Voor de 50 soort-gebiedscombinaties is dit in het kader van dit rapport nog niet onderzocht.

Voor de hier gebruikte data geldt dat de vangstkans onder andere afhangt van hoe lang er gevist is (inspanning) en met welk vistuig. Met deze twee afhankelijkheden is wel rekening gehouden door alle vangstgegevens te standaardiseren door te corrigeren voor de inspanning.

\subsubsection{Stap 5. Presenteer het statistische model}

In deze stap dient het statistisch model dat gebruikt wordt in formulevorm gepresenteerd te worden (voor details zie Zuur \& Ieno, 2016).

De keuze voor statistische modellen voor trendanalyses van HR-vispopulaties in Natura 2000-gebieden wordt sterk ingekaderd door de volgende eigenschappen van de visgegevens waarmee gewerkt wordt:

1. Er zijn geen census-tellingen: niet de hele populatie wordt geteld. Er wordt maar een klein deel van het bestand geteld, in een korte periode (omdat monitoren van vis duur en arbeidsintensief is).

2. Er zijn voor de meeste gegevensreeksen veel nul-waarnemingen. Van veel bestanden wordt in de meeste trekken niks gevangen, terwijl de vissoort waarschijnlijk / mogelijk wel in het gebied aanwezig is. Dit wordt ook nog eens versterkt doordat sommige vissoorten in (grote) scholen leven en andere meer solitair. Ook het habitat waar een soort voorkomt heeft grote invloed op de vangbaarheid. Soorten die niet pelagisch of op de bodem leven maar vooral tussen waterplanten en stortsteen, hebben een veel kleinere kans om gevangen te worden.

3. De inspanning waarmee vis wordt gevangen (bv. bij fuiken: fuik-etmalen) verschilt sterk; er moet dus in de modellen rekening worden gehouden met de mate van inspanning.

4. Monitoringprogramma's (surveys) zijn vaak aangepast of gestopt. Het gevolg hiervan is dat voor veel bestanden maar korte jaarreeksen beschikbaar zijn. Er is meestal geen/weinig overlap in de tijd, de bemonsteringsmethodieken verschillen vaak sterk en er is geen informatie beschikbaar om de verschillen te kwantificeren.

Daarnaast gelden nog de volgende kaders:

- De meeste tijdreeksen van andere biologische soortgroepen voor de 6-jaarlijkse

Habitatrichtlijn Art. 17-rapportage (zie §1.3) worden statistisch geanalyseerd door het CBS. In de analyse van de visgegevens zal zoveel mogelijk worden aangesloten bij de methodiek van de andere biologische soortgroepen zoals toegepast door het CBS.

- Getracht wordt eenzelfde statistisch model toe te passen op alle tijdreeksen. Dit zorgt voor een zo eenduidig mogelijke interpretatie.

In de datasets van de soort-gebiedscombinaties is het belangrijkste argument voor de keuze tussen verschillende statistische methodes het frequent voorkomen van nulwaarnemingen. Daarom worden op dit moment de volgende 2 methodes voorgesteld:

1. GLM op getelde aantallen.

Een Generalized Linear Model (GLM) op de aantallen heeft de voorkeur, omdat het een trend in aantallen oplevert. De methode kan toegepast worden op de werkelijk getelde aantallen of als loglineaire regressie. De methode kan echter alleen toegepast worden op soorten die veel gevangen worden, d.w.z. een bestand met niet te veel nullen. Zero-inflated modellen (model gebaseerd op een zero-inflated distributie; een distributie waarbij veel nullen toegestaan zijn) bieden voor de visgegevens geen oplossing, omdat er vrijwel geen variabelen beschikbaar zijn die het optreden van nulwaarnemingen kunnen verklaren. Indien bij de toepassing van de 
GLM op getelde aantallen bij een soort-gebiedscombinatie geen significantie wordt gevonden, wordt vervolgens alsnog onderstaande methode toegepast.

2. GLM op de aan-/afwezigheid van de soort in een vangst.

Voor soort-gebiedscombinaties met veel nulwaarnemingen wordt voorgesteld om de getelde aantallen om te zetten in aan-/afwezigheid. Wanneer de soort gevangen is, wordt een 1 genoteerd, ongeacht de gevangen aantallen. Wanneer de soort niet gevangen is wordt een 0 genoteerd. Weliswaar wordt hiermee ook het niveau waarop de trends worden beoordeeld globaler (van trends in aantallen naar trends in "kans dat de soort wordt gevangen"), maar de winst is dat voor meer soort-gebiedscombinaties significante trends zullen kunnen worden bepaald. De trendanalyse wordt uitgevoerd in een GLM met een binomiale link-functie, oftewel een logistische regressie.

Er bestaan geen harde regels voor wanneer welk model toegepast moet worden. In algemene zin kan gezegd worden dat wanneer een soort op de meeste stations in de meeste jaren wordt gevangen, een GLM op de aantallen kan worden toegepast. Een analyse op aan-/afwezigheid zal in dat geval waarschijnlijk geen trend opleveren. Aan de andere kant van het spectrum zitten soorten die zo af en toe opduiken in de data. Daar zal alleen een analyse op aan-/afwezigheid zin hebben.

Bij twijfel over welke methode het best kan worden toegepast, kan gekeken worden naar de standaardfouten van de resultaten van de trendanalyse. Indien bij de toepassing van de GLM-methode op aantallen op een soort-gebiedscombinatie geen significante trend wordt gevonden, kan vervolgens alsnog de GLM-methode op aan/afwezigheid worden toegepast.

\subsubsection{Stap 6. Fit het model}

In deze stap wordt het model toegepast op de data (voor details zie Zuur \& Ieno, 2016). Dit wordt met een R-script gedaan. De R-scripts zijn niet opgenomen in dit rapport, maar zijn beschikbaar bij Wageningen Marine Research.

\subsubsection{Stap 7. Valideer het model}

In dit onderdeel wordt onderzocht of het model voldoet aan de onderliggende aannames, zoals onafhankelijkheid van residuen. Een residu is het verschil tussen de gemodelleerde waarde en de geobserveerde waarde. Dit kan worden onderzocht door te kijken of er geen patronen zitten in de residuen (voor details zie Zuur \& Ieno, 2016).

\subsubsection{Stap 8. Interpreteer en presenteer de numerieke output van het model}

In dit onderdeel wordt de output van het model in tabelvorm weergegeven, zoals de geschatte regressieparameters, standaardfouten, z-waarden, en P-waarden of betrouwbaarheidsintervallen. In tekst wordt beschreven wat de trend is (voor details zie Zuur \& Ieno, 2016).

\subsubsection{Stap 9. Creëer een visuele voorstelling van het model.}

Per soort-gebiedscombinatie wordt een grafiek getoond van het gebruikte model, met daarin de datapunten en betrouwbaarheidsintervallen. 


\subsection{Toepassing statistiek op twee voorbeelden}

\subsubsection{Voorbeeld van GLM op getelde aantallen: zeeprik in de Voordelta}

Stap 1: Onderzoeksvraag.

De onderzoeksvraag luidt: wat is de trend van de populatie van zeeprik in de Voordelta voor de periode 2008-2018? De Voordelta is in 2008 aangewezen als Natura 2000-gebied en in dit geval is daarom met data van 2008 tot met 2018 gewerkt.

Stap 2: Kaart met monsterpunten

Zie bijlage 3, Voordelta, FGRF (Fuik).

Stap 3: Data exploratie

\section{FGRF}

Voor de zeeprik in de Voordelta zijn data uit de jaren 1995-2018 beschikbaar (Figuur 2) van twee locaties (32 Haringvliet est. (estuarium) en 34 Haringvliet est.), bemonsterd in de maanden maart, april, mei en juni. Deze locaties liggen relatief dichtbij de Haringvlietsluizen en zijn daarom niet representatief voor de gehele Voordelta. In Figuur 2 zijn gemiddelde CPUEs per fuiklichting weergegeven voor beide stations samen. Datapunten kunnen overlappen (bv de nullen). We hebben ervoor gekozen niet elke locatie met een aparte kleur weer te geven, omdat dit in het geval van meerdere meetlocaties een onoverzichtelijke grafiek oplevert.

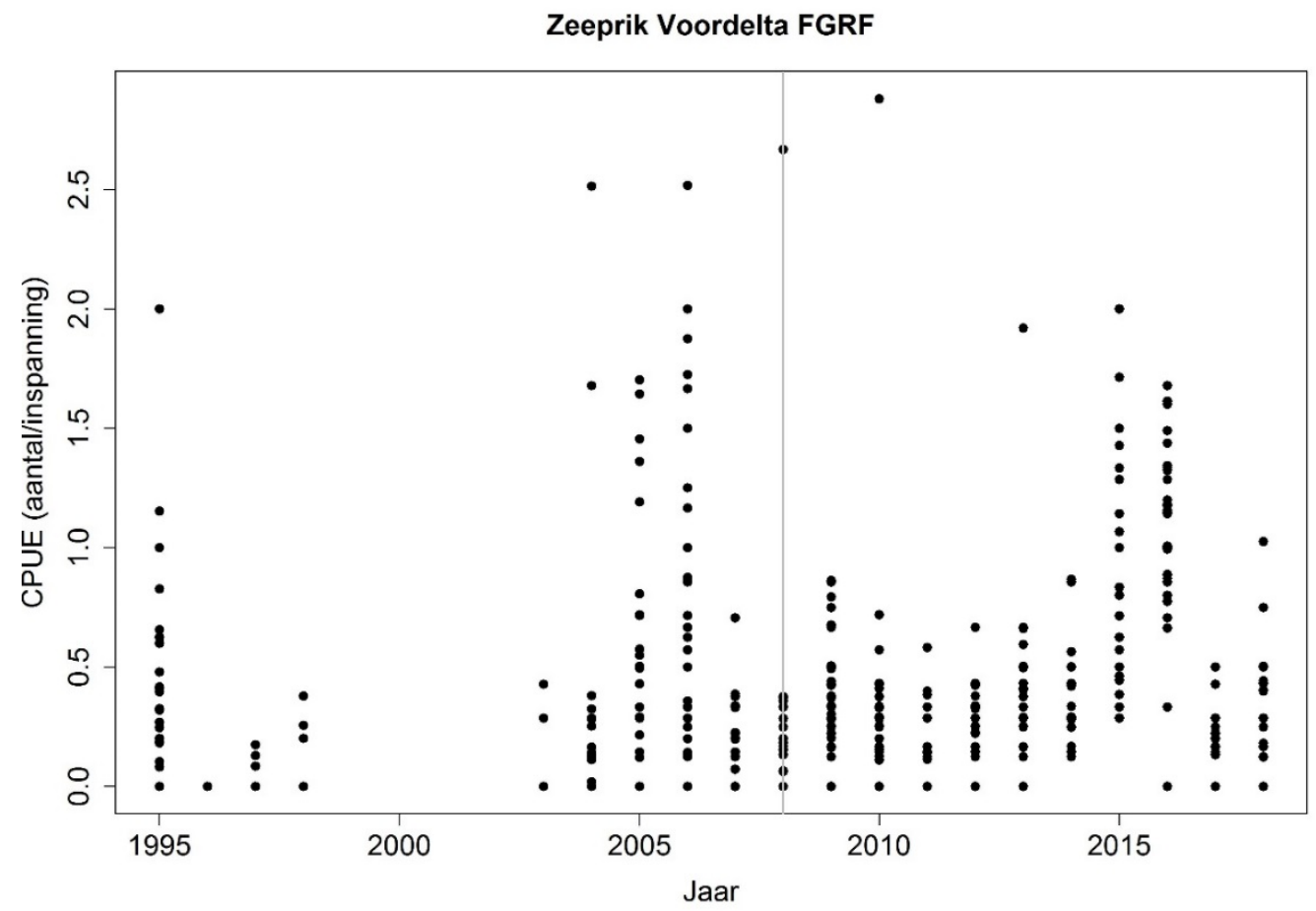

Figuur 2. Vangst per eenheid inspanning (CPUE) per bemonstering voor zeeprik in fuiken in de Voordelta. De grijze lijn geeft het jaar van aanwijzing weer van het Natura 2000-gebied.

De data is daarna voor toepassing in het model opgewerkt door de gegevens eerst per fuiklichting te sommeren. Daarna zijn deze gegevens per vanglocatie per jaar gemiddeld. De vangsten per jaar per locatie zijn weer over de (twee) locaties gemiddeld waardoor er één gemiddelde vangst per jaar kan worden berekend. De vangsten zijn niet nog eens per maand gemiddeld.

In dit voorbeeld hangt de vangkans samen met het type vangtuig en met de vangstinspanning. 


\section{Stap 5: Het statistische model}

De analyses zijn uitgevoerd in R (R Core Team, 2018). In R-syntax wordt het model (loglineaire regressie, met quasipoissonverdeling) als volgt beschreven:

$$
\text { aantal jaar + vangtuig + offset(log(offset)), family=quasipoisson) }
$$

De "vangstinspanning" is in de meeste gevallen bekend en wordt in de analyse meegenomen als offset (een weegfactor). Op deze manier wordt de vangstkans gecorrigeerd voor de vangstinspanning. De jaarcijfers zijn de gemiddelde aantallen gevangen zeeprikken per jaar.

\section{Stappen 6 en 7: Fitten en validatie van het model}

Of er sprake is van een significante trend valt af te leiden uit de output van de analyse. De typische output van een loglineaire regressie in $\mathrm{R}$ ziet er als volgt uit:

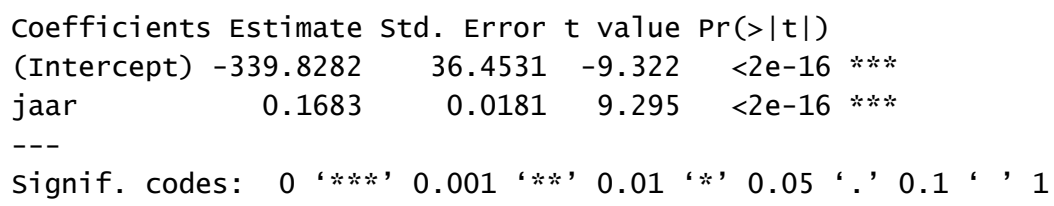

In deze output ontbreekt het vangtuig, omdat er alleen met de gegevens van één vangtuig (de fuik) gerekend is.

Het gefitte model luidt dus:

$$
\text { aantal 0,1683 jaar + offset(log(offset)), family=quasipoisson) }
$$

Als het jaareffect (hier: 0,1683 ) significant is (zie kolom "Pr $(>|t|)$ ", is er sprake van een significante toe- of afname in de kans dat de soort wordt gevangen. Omdat het jaareffect positief is, gaat het hier om een toename. Het jaareffect is gegeven op een log-schaal (vanwege de loglineaire regressie) en kan terug-getransformeerd worden naar de oorspronkelijke schaal volgens de volgende formule:

$$
\text { Trend }=\exp (\text { jaareffect })
$$

De standaardfout van de trend op de oorspronkelijke schaal kan berekend worden als:

$$
\text { SE trend }=S E \_ \text {jaareffect } * \text { Trend, }
$$

waarin SE_jaareffect de standaardfout is van het jaareffect in de R-output (hier 0,0181).

In het geval van de zeeprik in de Voordelta is dus sprake van een trend van $\exp (0,1683)=1,18$ met een standaardfout van $1,18 * 0,0181=0,0214$. Een trend van 1,18 betekent dat de soort per jaar met $18 \%$ toeneemt in de periode 2008-2018. Bij de trend hoort ook een betrouwbaarheidsinterval dat aangeeft hoe betrouwbar de trend is.

De trend en de standaardfout kunnen worden gebruikt om de trend te beoordelen volgens dezelfde methode als in het Netwerk Ecologische Monitoring (NEM). Daartoe worden eerst de ondergrens en bovengrens van het $95 \%$ betrouwbaarheidsinterval berekend, volgens:

$$
\begin{aligned}
& \text { lower } \mathrm{CL}=\text { Trend }-1,96 * \mathrm{SE} \text { Trend } \\
& \text { upper } \mathrm{CL}=\text { Trend }+1,96 * \mathrm{SE} \text { Trend }
\end{aligned}
$$

Op basis van deze grenzen wordt de volgende classificatie toegepast: 
Tabel 9. Classificatie van trends op aantallen berekend met een GLM volgens de NEM methode. CL= Confidence Limit (betrouwbaarheidsinterval) (bron: Soldaat et al., 2007).

\begin{tabular}{|c|c|}
\hline Categorie & Criteria \\
\hline Sterke toename & $\begin{array}{l}\text { lower } \mathrm{CL}>1.05 \\
\text { (significante toename van meer dan } 5 \% \text { per jaar) }\end{array}$ \\
\hline Matige toename & $\begin{array}{l}1.00<\text { lower } \mathrm{CL} \leq 1.05 \\
\text { (significante toename, maar niet significant meer dan } 5 \% \text { per jaar) }\end{array}$ \\
\hline Stabiel & $\begin{array}{l}\text { CI includes } 1.00 \text { AND } 0.95 \leq \text { lower CL AND upper } C L \leq 1.05 \\
\text { (geen significante toename of afname, veranderingen zijn kleiner dan } 5 \% \text { per jaar) }\end{array}$ \\
\hline Onzeker & $\begin{array}{l}\text { lower } \mathrm{CL}<0.95 \text { AND } 1.05<\text { upper } \mathrm{CL} \\
\text { (omvang verandering niet goed vast te stellen) }\end{array}$ \\
\hline Matige afname & $\begin{array}{l}0.95 \leq \text { upper } \mathrm{CL}<1.00 \\
\text { (significante afname, maar niet significant meer dan } 5 \% \text { per jaar) }\end{array}$ \\
\hline Matige toename & $\begin{array}{l}\text { upper } \mathrm{CL}<0.95 \\
\text { (significante afname van meer dan } 5 \% \text { per jaar) }\end{array}$ \\
\hline
\end{tabular}

De ondergrens van het betrouwbaarheidsinterval voor de zeeprik in de Voordelta is $1,18-1,96 * 0,0214$ $=1,14$. Daarmee wordt de trend beoordeeld als "sterke toename". 
Stap 8. Visuele voorstelling.

Het resultaat voor de zeeprik in de Voordelta is te zien in Figuur 3.

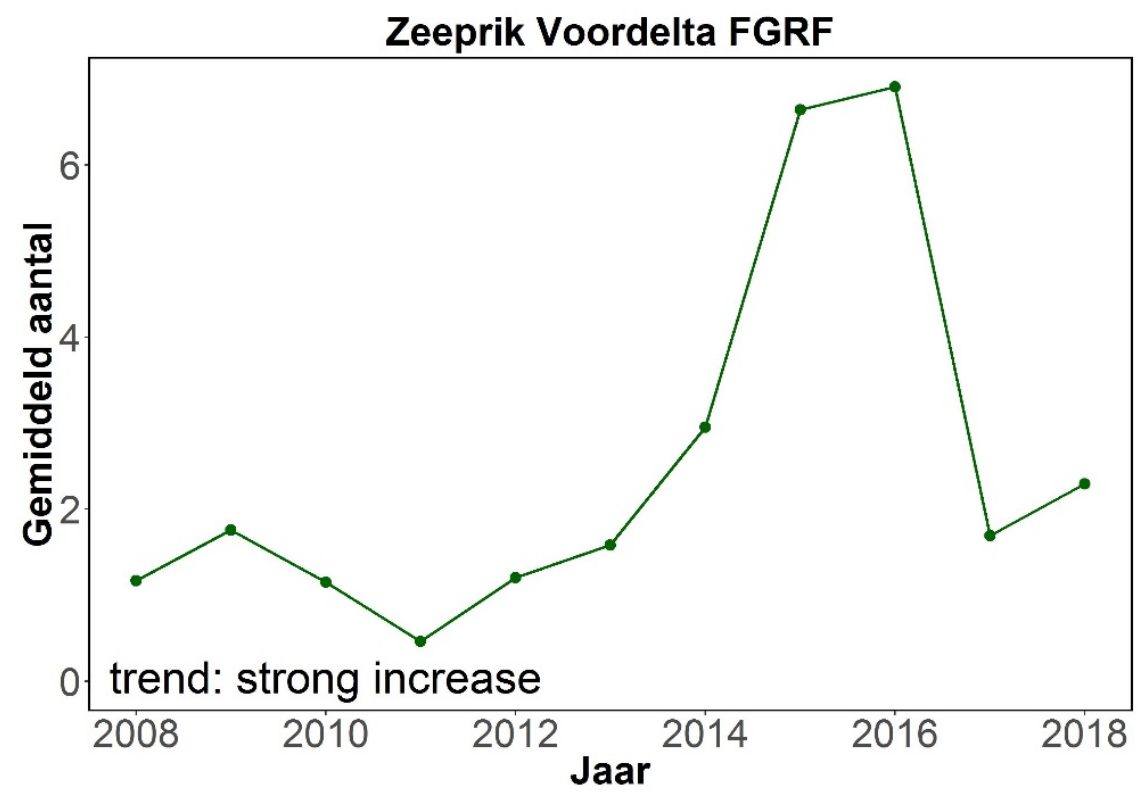

Figuur 3. Gemiddeld aantal gevangen zeeprikken in de Voordelta in de periode 2008-2018.

\subsubsection{Voorbeeld van GLM op de aan-/afwezigheid van de soort in een vangst: rivierdonderpad in het Haringvliet}

\section{Stap 1: Onderzoeksvraag}

De onderzoeksvraag luidt: wat is de trend van de populatie van rivierdonderpad in het Haringvliet voor de periode 2015-2018? Het Haringvliet is in 2015 aangewezen als Natura 2000-gebied en in dit voorbeeld zijn data beschikbaar van 2011-2018 voor de FGRA met de boomkor.

Stap 2: Kaart met monsterpunten

Zie Bijlage 3, kaart Haringvliet, dataserie FGRA.

\section{Stap 3: Data exploratie}

Er is één dataserie beschikbaar (Figuur 4). Vanaf 2011 wordt de visstand in het open water met de boomkor gestandaardiseerd gemonitord. De data is opgewerkt door de gegevens eerst per trek te sommeren. Daarna zijn deze gegevens per vanglocatie per jaar gemiddeld. In Figuur 4 zijn deze punten weergegeven. Omdat in de meeste trekken geen rivierdonderpadden voorkomen, is de CPUE van de meeste punten 0 , waardoor er in de grafiek weinig punten lijken te staan.

Als input voor het model zijn de vangsten per jaar per locatie over de locaties gemiddeld waardoor er één gemiddelde vangst per jaar kan worden berekend. De vangsten zijn niet nog eens per maand gemiddeld.

Stap 4: Afhankelijkheden.

De vangkans van de rivierdonderpad hangt samen met de inspanning (vangstduur) en het vistuig.

\section{Stap 5: Het statistische model}

De trendanalyse wordt uitgevoerd met een logistische regressie (aan-/afwezigheidsdata) over data vanaf 2015, vanwege het grote aantal nullen. De responsevariabelen zijn de 0-en en 1-en uit de afzonderlijke bemonsteringen. De belangrijkste verklarende variabele is het jaar van de bemonstering, waaruit de trend wordt berekend. De "vangstinspanning" is in de meeste gevallen bekend en wordt in de analyse verdisconteerd als offset (een weegfactor). Op deze manier wordt de vangstkans gecorrigeerd voor de vangstinspanning. 
De analyse is uitgevoerd in R. In R-syntax wordt het model (logistische regressie) als volgt beschreven:

$P($ visgevangen $) \sim$ jaar + offset $(\log ($ offset $))$, family=binomial(link='logit' $))$

De jaarcijfers zijn de jaarlijkse vangstkansen, berekend als het gemiddelde van de 0-en en 1-en per jaar.

\section{Rivierdonderpad Haringvliet Boomkor FGRA}

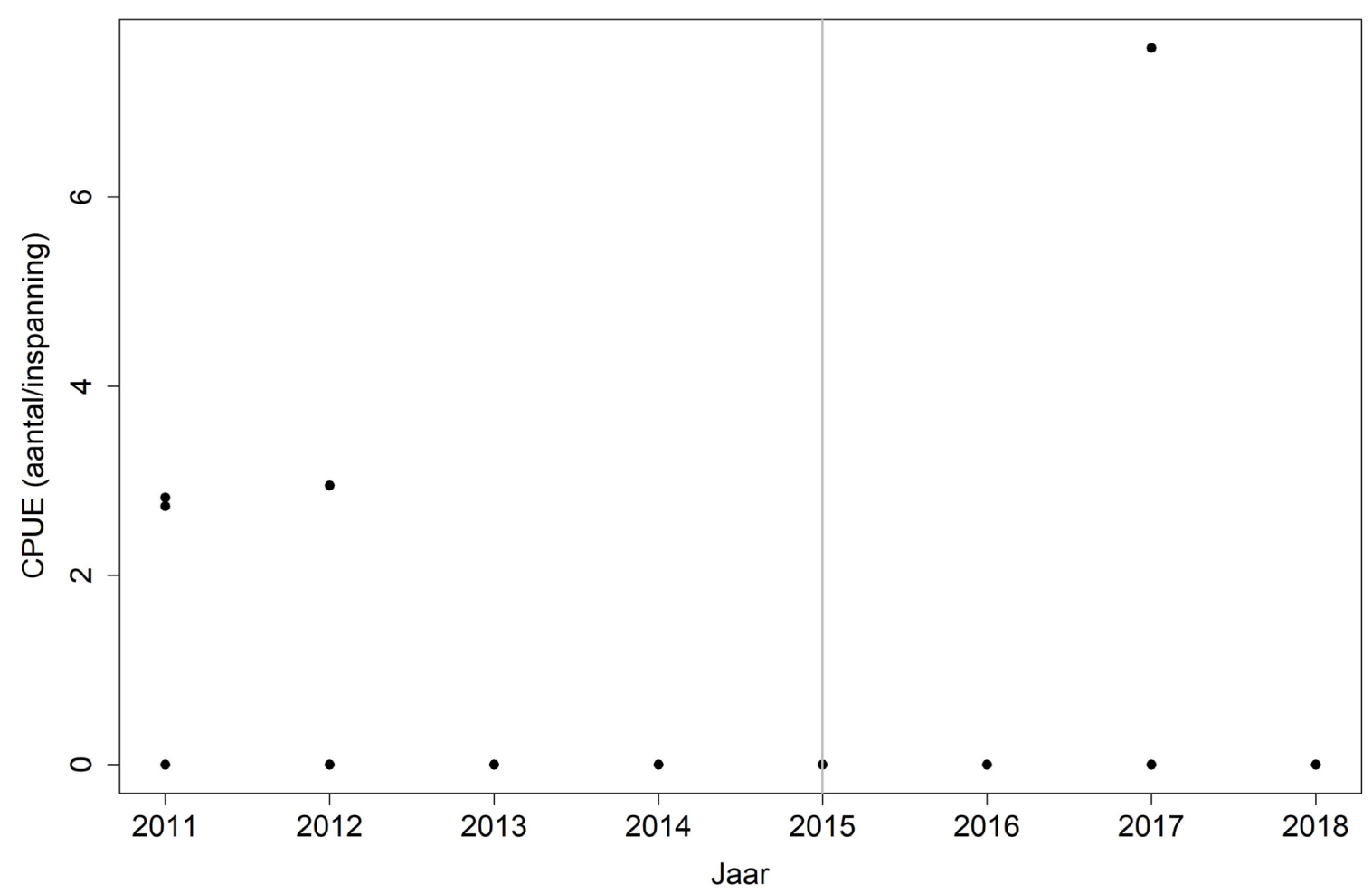

Figuur 4. Vangst per eenheid inspanning (CPUE) voor rivierdonderpadden in het Haringvliet voor boomkor per vangstlocatie per jaar. Omdat op de meeste vangstlocaties geen rivierdonderpadden worden gevangen, hebben de meeste punten de waarde 0. De grijze lijn geeft het jaar van aanwijzing aan van het Natura 2000-gebied.

Stappen 6 en 7: Fitten en validatie van het model

Of er sprake is van een significante trend valt af te leiden uit de output van de analyse. De typische output van een logistische regressie in $\mathrm{R}$ ziet er als volgt uit:

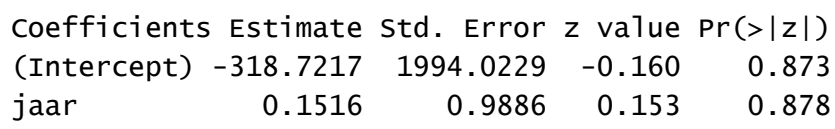

Als het jaareffect (hier: 0,1516$)$ significant is (zie kolom " $\operatorname{Pr}(>|z|$ )", is er sprake van een significante toe- of afname in de kans dat de soort wordt gevangen. Omdat het jaareffect positief is, gaat het hier om een toename, alhoewel deze dus niet significant is ( $\mathrm{Pr}>0.1$ ). Het jaareffect is gegeven op een log-schaal en kan, om enig begrip te krijgen voor de betekenis, omgerekend worden naar de oorspronkelijke schaal volgens de volgende formule:

$$
\text { Trend }=\exp (\text { jaareffect }) /(1+\exp (\text { jaareffect }))
$$


In het voorbeeld resulteert dit in:

$$
\text { Trend }=\exp (0,1516) /(1+\exp (0,1516))=0.538
$$

Dat betekent dat de vangstkans per jaar 100-53,8=46,2\% lijkt te stijgen, hoewel dit dus niet significant is. Deze niet significante stijging wordt veroorzaakt door de vangst van rivierdonderpadden in 2017 (Figuur 5).

Ten slotte kan de Pr-waarde ook gebruikt worden om een trendclassificatie op te baseren. Er is nog geen gestandaardiseerde beoordelingsmethode beschikbaar zoals bij de trends in aantallen. Daarom is uitgegaan van de criteria uit Tabel 10. Eventueel kan de toe- en afname nog worden onderverdeeld in sterk en matig, op basis van de sterkte van het jaareffect.

Tabel 10. Classificatie van trends op aan/afwezigheid berekend met een GLM volgens de NEM methode.

\begin{tabular}{ll} 
Categorie & Criteria \\
Afname & jaareffect $<0$ en $\operatorname{Pr}<0,05$ \\
\hline Toename & jaareffect $>0$ en $\operatorname{Pr}<0,05$ \\
\hline Stabiel & geen toe- of afname en $\operatorname{Pr}<0,1$ \\
\hline Onzeker & geen toe- of afname en $\operatorname{Pr}>0,1$ \\
\hline
\end{tabular}

Gegeven het jaareffect van 0.1516 en $\mathrm{Pr}>0.1$, wordt de trend beoordeeld als 'Onzeker'.

Stap 8. Visuele voorstelling.

Het resultaat voor de rivierdonderpad in het Haringvliet is te zien in Figuur 5.

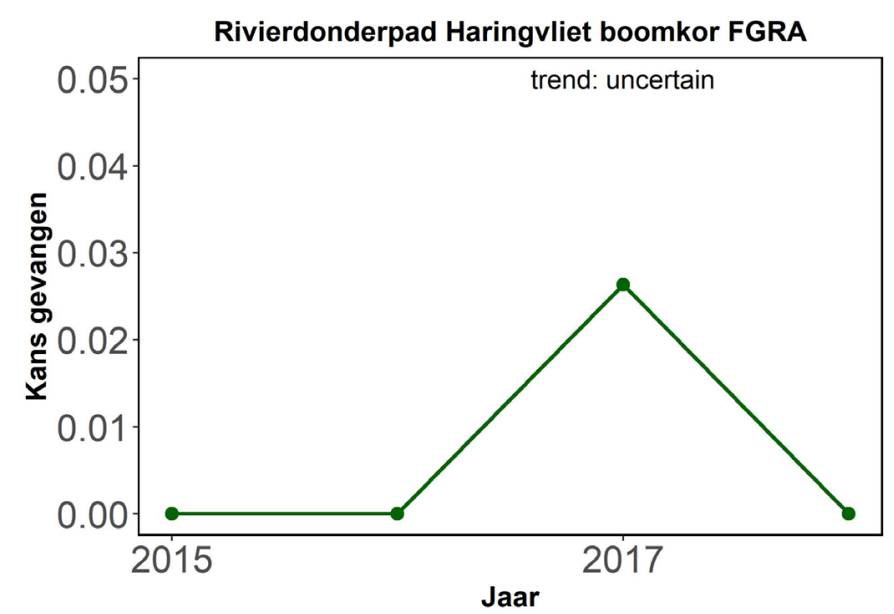

Figuur 5. Vangkans rivierdonderpadden in het Haringvliet in de periode 2015-2018. 


\subsection{Aanpak evaluatie doelbereik}

Het doelbereik wordt bepaald door de statistische uitkomst van de trendanalyse te vergelijken met de instandhoudingsdoelstelling voor een bepaalde HR-vissoort in een Natura 2000-gebied. Als het doel bijvoorbeeld 'uitbreiding populatie' is, dan is het doel bereikt als aangetoond kan worden dat de populatie een significante positieve trend vertoont.

Hiertoe zijn de instandhoudingsdoelstellingen uit de aanwijzingsbesluiten omgezet in statistisch toetsbare doelen (Tabel 11). De volgende redeneringen zijn hierbij gevolgd:

- Bij de instandhoudingsdoelstelling 'behoud populatie' dient de populatiegrootte statistisch gezien, rekening houdend met het 95\%-betrouwbaarheidsinterval, ten minste gelijk te blijven (hier omschreven als " trend $=0 "$ ). We gaan ervan uit dat groei van de populatie ("trend $>$ $0^{\prime \prime}$ ) ook als gunstig wordt beschouwd. Alle trends gelijk aan of groter dan nul $(>=0)$ worden daarom beoordeeld als gunstig.

- Bij de instandhoudingsdoelstelling 'uitbreiding populatie' moet de populatiegrootte statistisch gezien, rekening houdend met het 95\%-betrouwbaarheidsinterval, significant toenemen en wordt een trend groter dan nul $(>0)$ als gunstig beschouwd, en een trend gelijk aan of kleiner aan nul $(<=0)$ als ongunstig.

Tabel 11. De verschillende instandhoudingsdoelstellingen uit de aanwijzingsbes/uiten, met vertaling naar een statistische beoordeling van populatietrend. = gelijk aan, < kleiner dan, > groter dan. Toelichting: zie paragraaf 2.1. Voor de methodiek in dit rapport zijn de doelen t.a.v. leefgebied niet van belang. In Tabel 13 staat een overzicht van de doelen per soort en gebied.

\begin{tabular}{|c|c|c|}
\hline Doel in aanwijzingsbesluit & $\begin{array}{l}\text { Doel } \\
\text { populatie }\end{array}$ & Statistische beoordeling trend populatie \\
\hline $\begin{array}{l}\text { Behoud omvang en kwaliteit leefgebied voor behoud } \\
\text { populatie. }\end{array}$ & $=$ & $\begin{array}{l}\text { Gunstige trend populatie: trend }>=0 \\
\text { Ongunstige trend populatie: trend }<0\end{array}$ \\
\hline $\begin{array}{l}\text { Behoud omvang en kwaliteit leefgebied voor behoud } \\
\text { populatie. Enige achteruitgang in oppervlakte } \\
\text { leefgebied ten gunste van broedvogelsoorten } \\
\text { roerdomp (A021) of grote karekiet (A298) is } \\
\text { toegestaan (dit is het doel voor de rivierdonderpad } \\
\text { in Natura 2000-gebied 'Veluwe Randmeren') }\end{array}$ & $=$ & $\begin{array}{l}\text { Gunstige trend populatie: trend }>=0 \\
\text { Ongunstige trend populatie: trend }<0\end{array}$ \\
\hline $\begin{array}{l}\text { Behoud omvang en kwaliteit leefgebied voor } \\
\text { uitbreiding populatie. }\end{array}$ & $>$ & $\begin{array}{l}\text { Gunstige trend populatie: trend }>0 \\
\text { Ongunstige trend populatie: trend }<=0\end{array}$ \\
\hline $\begin{array}{l}\text { Behoud omvang en verbetering kwaliteit leefgebied } \\
\text { voor uitbreiding populatie. }\end{array}$ & $>$ & $\begin{array}{l}\text { Gunstige trend populatie: trend }>0 \\
\text { Ongunstige trend populatie: trend }<=0\end{array}$ \\
\hline $\begin{array}{l}\text { Uitbreiding omvang en kwaliteit leefgebied voor } \\
\text { uitbreiding populatie }\end{array}$ & $>$ & $\begin{array}{l}\text { Gunstige trend populatie: trend }>0 \\
\text { Ongunstige trend populatie: trend }<=0\end{array}$ \\
\hline $\begin{array}{l}\text { Uitbreiding omvang en kwaliteit leefgebied voor } \\
\text { uitbreiding populatie en verspreiding leefgebied }\end{array}$ & $>$ & $\begin{array}{l}\text { Gunstige trend populatie: trend }>0 \\
\text { Ongunstige trend populatie: trend }<=0\end{array}$ \\
\hline
\end{tabular}

Na statistische analyse van de data moeten de resultaten door een expert op waarde geschat en geïnterpreteerd worden om aanvullende informatie te geven over bv. de achterliggende redenen van bijvoorbeeld een populatietoename. Hierbij wordt rekening gehouden met beschikbare langere termijn data, met eerdere beoordelingen en met andere relevante informatie die niet in de analyse is meegenomen. Expert judgement kan de volgende zaken behandelen:

- Toelichting op de geconstateerde trend (hoe sterk is de toe- of afname, wat is hiervan de achterliggende reden, ligt het in de lijn der verwachting, hoe zit het met trends in voorgaande evaluatieperioden, etc.)

- $\quad$ Context waarin de trend gezien moet worden (in hoeverre komt de trend binnen het Natura 2000-gebied overeen met die in andere Natura 2000-gebieden en (inter)nationaal?) 


\subsubsection{Twee voorbeelden}

Wanneer de conclusies uit de statistische analyses van de 2 voorbeelden van soortgebiedscombinaties vergeleken worden met de instandhoudingsdoelstellingen, kan het doelbereik bepaald worden. In Tabel 12 staan de resultaten van deze vergelijking.

Tabel 12. Evaluatie doelbereik.

\begin{tabular}{lllll}
$\begin{array}{l}\text { Natura } \\
2000- \\
\text { gebied } \\
\text { Voordelta }\end{array}$ & Zeeprik & $>$ & $\begin{array}{l}\text { Classificatie } \\
\text { populatie } \\
\text { populatietrend }\end{array}$ & $\begin{array}{l}\text { Evaluatie } \\
\text { doelbereik }\end{array}$ \\
\hline Haringvliet & $\begin{array}{l}\text { Rivier- } \\
\text { donderpad }\end{array}$ & $=$ & Sterke toename & Doel gehaald \\
\hline & Onzeker & $\begin{array}{l}\text { Haalbaarheid } \\
\text { doel niet te } \\
\text { bepalen aan de } \\
\text { hand van } \\
\text { huidige } \\
\text { monitoringsdata }\end{array}$ \\
\hline
\end{tabular}

Vervolgens worden in de laatste stap de resultaten in een context gezet door middel van expertjudgement en literatuuronderzoek.

Zeeprik in de Voordelta: In de Voordelta neemt de zeeprik in twee jaren sterk toe, terwijl er de laatste twee jaar een terugval te zien is geweest in vergelijking met de voorgaande jaren. Het is onduidelijk wat hieraan ten grondslag ligt. Over de langere tijdreeks vanaf 1995 is eerder een periode met een toename, gevolgd door een terugval (2006-2013), geweest (Figuur 2). De verwachting is dat de soort in de toekomst toeneemt omdat er nu betere migratiemogelijkheden zijn, als gevolg van de uitvoering van het Kierbesluit. De monitoring vindt echter op twee plaatsen relatief dichtbij de Haringvlietsluizen plaats en is daarom niet representatief voor de gehele Voordelta.

Rivierdonderpad in het Haringvliet: De trend van de rivierdonderpad is onzeker in het Haringvliet. De soort leek in de beginjaren van de monitoring $(2011,2012)$ vaker gevangen te zijn, wat kan duiden op achteruitgang. Eén van de mogelijke redenen hiervoor is dat de soort concurrentie heeft gekregen van een aantal exotische grondelsoorten uit de Ponto-Kaspische regio die hetzelfde habitat gebruiken, zoals marmergrondel, zwartbekgrondel, Kesslers grondel en Pontische stroomgrondel (Tien et al. 2019).

\subsection{Template voor rapportage}

Om op een gestandaardiseerde wijze te kunnen rapporteren over de evaluatie van beheerplannen is in dit rapport een template ontwikkeld (Bijlage 2). 


\section{$4 \quad$ Samenvatting beoordelingsmethodiek}

De hier ontwikkelde methodiek bestaat samengevat uit de volgende uitgangspunten en stappen:

\subsection{Uitgangspunten}

- De hier ontwikkelde methodiek gaat over vissen van de Habitatrichtlijn Annex II die beschermd worden in Natura 2000-gebieden in rijkswateren en waarvoor instandhoudingsdoelstellingen gelden, zoals beschreven in de aanwijzingsbesluiten van de Natura 2000-gebieden.

- Elk Natura 2000-gebied heeft een beheerplan dat minimaal 6 jaar geldig is (beheerplanperiode).

- De beoordelingsmethodiek moet aantonen of de trend van een HR-vissoort in een bepaald Natura 2000-gebied na afloop van een Natura 2000-beheerplanperiode van 6 jaar (of van 2 periodes, 12 jaar, etc.) voldoet aan de instandhoudingsdoelstelling uit het aanwijzingsbesluit voor het Natura 2000-gebied.

- Uitgangspunt voor de statistische trendanalyse is: de populatietrend wordt vastgesteld vanaf het jaar van aanwijzing van het Natura 2000-gebied.

- Data en informatie over eerdere periodes (bv. jaren '80, '90, etc.) wordt gebruikt om de populatietrend in een bredere context te plaatsen (langetermijnontwikkeling).

- Informatie uit voorgaande beheerplanevaluaties wordt meegenomen in de beoordeling.

- Per HR-vissoort kunnen per Natura 2000-gebied meerdere datasets worden gebruikt voor meerdere trendanalyses (geen beperking tot 1 dataset).

\subsection{Stap 1. Dataselectie}

Uit een zo compleet mogelijk overzicht van zoet- en zoutwaterdata zijn door een expert (visecoloog) één of meerdere dataseries geselecteerd die representatief zijn voor de soort in een bepaald Natura 2000-gebied. Deze selectie is gemaakt op basis van een aantal selectiecriteria (Tabel 6).

\subsection{Stap 2. Statistische analyse}

De protocollen van Zuur \& Ieno (2016) en Zuur et al. (2010) worden gevolgd om op een standaard manier data te analyseren. Het protocol bestaat uit een aantal stappen, waarbij de onderzoeksvraag wordt uitgeschreven, de datapunten op een kaart worden getekend (per soort per Natura 2000gebied), data-verkenning wordt uitgevoerd, de afhankelijkheden binnen de data worden verkend, het te gebruiken statistische model wordt beschreven, het statistisch model wordt gefit en daarna gevalideerd (zit er een patroon in de residuen of niet). Daarna worden de uitkomsten gepresenteerd (in tekst en grafieken) en geïnterpreteerd.

Afhankelijk van de kwaliteit van de data wordt een van onderstaande methodes gebruikt om trends te bepalen:

- GLM op getelde aantallen. Dit heeft de voorkeur, omdat het een trend in aantallen oplevert. De methode kan toegepast worden op de werkelijk getelde aantallen of als loglineaire regressie. De methode kan echter alleen toegepast worden op soorten die veel gevangen worden, d.w.z. een bestand met niet te veel nullen.

- GLM op de aan-/afwezigheid van de soort in een vangst. 
Voor de interpretatie dient zowel een grafiek gemaakt te worden van de data vanaf het beginjaar van de bemonstering als een grafiek vanaf het jaar van aanwijzing van het Natura-2000 gebied. De eerste grafiek dient om inzicht te krijgen in de ontwikkeling op langere termijn van de populatie. De tweede grafiek dient om inzicht te krijgen in de data waarmee statistische analyses worden gedaan.

\subsection{Stap 3. Evaluatie doelbereik}

Het doelbereik wordt bepaald door de statistische uitkomst van de trendanalyse te vergelijken met de instandhoudingsdoelstelling voor een bepaalde HR-vissoort in een Natura 2000-gebied. Als het doel bijvoorbeeld 'uitbreiding populatie' is, dan is het doel bereikt als aangetoond kan worden dat de populatie statistisch gezien een significante positieve trend vertoont ten opzichte van het referentiejaar (voor overzicht te toetsen doelen: zie Tabel 13).

Statistiek zegt niet altijd alles. Daarom zullen de resultaten uit de analyse daarnaast altijd door een expert (ecoloog) geïnterpreteerd moeten worden. Expert judgement kan de volgende zaken behandelen:

- $\quad$ toelichting op de geconstateerde trends (hoe sterk is de toe- of afname, wat is hiervan de achterliggende reden, etc.)

- $\quad$ context waarin de trends gezien moeten worden (in hoeverre komt de trend binnen het Natura 2000-gebied overeen met die in andere Natura 2000-gebieden en (inter)nationaal?)

Er kan van een template gebruik worden gemaakt om de evaluatie op gestandaardiseerde manier te rapporteren (zie Bijlage 2). 


\section{$5 \quad$ Discussie en aanbevelingen}

In dit rapport zijn zo goed mogelijk voorstellen gedaan voor de dataselectie per soortgebiedscombinatie en voor een evaluatiemethode. Bij de daadwerkelijke evaluatie kan dit rapport als leidraad worden gebruikt, maar zal degene die de analyse uitvoert kritisch moeten blijven ten aanzien van de keuze van datasets (vistuigen/periode/locaties), statistische analysemethodes en inhoudelijke interpretatie van ruimtelijke schaalaspecten en tijdshorizonten. Daarnaast moet per soortgebiedscombinatie goed gecheckt worden of er afwijkingen/veranderingen in de bemonstering qua jaar, tuig, locatie etc. zijn. Dit is een lastige eigenschap van de database: het vangtuig (en dus de vangstkans) varieert vaak per locatie en de bemonstering van een bepaalde locatie kan om verscheidene redenen stopgezet zijn. Indien uit de evaluaties blijkt dat de hier ontwikkelde methodiek moet worden bijgesteld zou dat in een evaluatierapportage moeten worden vastgelegd, zodat dat in een volgende versie van dit handboek kan worden verwerkt.

Ligging monitoringslocaties: Voor sommige gebieden is een beperkt aantal monitoringslocaties beschikbaar of liggen locaties niet eens in het gebied (bv. Vlakte van de Raan). In dit rapport is gepoogd een systematiek te ontwikkelen die zo goed mogelijk omgaat met deze beperking. Daarbij kan het zijn dat voor kustgebieden zoals de Noordzeekustzone meetpunten een stuk verderop (Afsluitdijk) representatief worden geacht, die dat mogelijk toch niet zijn. Om de evaluatie van instandhoudingsdoelstellingen niet alleen van trends in vangsten te laten afhangen, weegt in de hier ontwikkelde systematiek daarom ook het expert-oordeel mee.

Beperkte tijdseries: In sommige gebieden (bv. Randmeren) wordt maar eens per 3 jaar bemonsterd. Bij een evaluatie van visdoelen over een periode van 6 jaar zijn in dat geval hoogstens 2 of 3 meetpunten beschikbaar. We bevelen aan om voor die gebieden ook een eerder meetpunt mee te nemen (bv 1 jaar vóór aanwijzing). Dit is nog niet getest.

In de hier ontwikkelde methodiek wordt halverwege (na 3 jaar), of na afloop van een beheerplanperiode (6 jaar) een instandhoudingsdoelstelling geëvalueerd. De referentiewaarde is de populatie op het moment van aanwijzing van het Natura 2000-gebied. Dat betekent in de praktijk dat de populatietrend in de toekomst in ieder geval na 6, 12 en 24 jaar etc. moet worden vergeleken met de referentiewaarde, waarbij analyses uit voorgaande evaluaties mee worden genomen bij de interpretatie. De lengte van de te analyseren dataset wordt in de toekomst dus steeds groter (tenzij het aanwijzingsbesluit wordt herzien). Hierin verschilt de methodiek met die gebruikt voor de Europese Art. 17-rapportage, waarin Nederland landelijke trends over de laatste 12 jaar moet rapporteren voor HR-soorten. 


\section{$6 \quad$ Kwaliteitsborging}

Wageningen Marine Research beschikt over een ISO 9001:2015 gecertificeerd kwaliteitsmanagementsysteem. Dit certificaat is geldig tot 15 december 2021. De organisatie is gecertificeerd sinds 27 februari 2001. De certificering is uitgevoerd door DNV GL. 


\section{Literatuur}

Min LNV (2005) Handreiking Beheerplannen Natura 2000-gebieden

(http://www.natura2000.nl/files/handreiking-beheerplannen-natura-2000.pdf).

Min LNV (2009) Natura 2000- essentietabellen Leeswijzer

(https://www.synbiosys.alterra.nl/natura2000/documenten/essentietabellen/essentietabel_leeswij zer.pdf).

R Core Team (2018). R: A language and environment for statistical computing. R Foundation for Statistical Computing, Vienna, Austria. (https://www.R-project.org/).

Soldaat L, Visser H, van Roomen M, van Strien A (2007) Smoothing and trend detection in waterbird monitoring data using structural time-series analysis and the Kalman filter. J Ornithol 148:351357 (https://link.springer.com/article/10.1007/s10336-007-0176-7).

Tien NSH, Griffioen AB, Van Keeken OA, Van Rijssel JC, de Leeuw JJ (2019) Vismonitoring Zoete Rijkswateren en Overgangswateren $\mathrm{t} / \mathrm{m}$ 2017. Deel I: Toestand en trends. Wageningen Marine Research (https://edepot.wur.nl/464551). Rapport C084/18A

Van der Hammen T, De Graaf M (2013) Recreational fishery in the Netherlands: demographics and catch estimates in marine and fresh water (http://edepot.wur.nl/279478). IMARES.

Van der Hammen T, De Graaf M (2015) Recreational fisheries in the Netherlands: analyses of the 2012 - 2013 online logbook survey, 2013 online screening survey and 2013 random digit dialing screening survey (http://edepot.wur.nl/338449). IMARES.

Van der Hammen T, De Graaf M (2017) Recreational fisheries in the Netherlands: Analyses of the 2015 screening survey, the 2014 - 2015 logbook survey and the 2014 - 2015 Gillnet survey (http://library.wur.nl/WebQuery/wurpubs/fulltext/409681). Stichting Wageningen Research, Centre for Fisheries Research (CVO).

Van der Sluis MT, Tien NSH, Griffioen AB, Van Keeken OA, Van Os-Koomen E, Wiegerinck JAM (2019) Vismonitoring Zoete Rijkswateren en Overgangswateren t/m 2017. Deel II Toegepaste methoden. Wageningen Marine Research (https://edepot.wur.nl/469620). Rapport C007/19a

Zuur AF, Ieno EN (2016) A protocol for conducting and presenting results of regression-type analyses (https://doi.org/10.1111/2041-210X.12577). Methods in Ecology and Evolution 7:636-645

Zuur AF, Ieno EN, Elphick CS (2010) A protocol for data exploration to avoid common statistical problems (https://doi.org/10.1111/j.2041-210X.2009.00001.x). Methods in Ecology and Evolution $1: 3-14$ 


\section{Verantwoording}

Rapport C005/20

Projectnummer: 4312100048

Dit rapport is met grote zorgvuldigheid tot stand gekomen. De wetenschappelijke kwaliteit is intern getoetst door een collega-onderzoeker en het verantwoordelijk lid van het managementteam van Wageningen Marine Research

Akkoord:

J. Vrooman

Handtekening:

onderzoeker

Datum:

23 januari 2020

Akkoord:

Drs. J. Asjes

Manager integratie

Handtekening:

Datum:

23 januari 2020 


\section{Bijlage 1 Instandhoudingsdoelstellingen}

Tabel 13. Instandhoudingsdoelstellingen met toelichting per soort per Natura 2000-gebied, met toegevoegd statistisch testbare doelen.

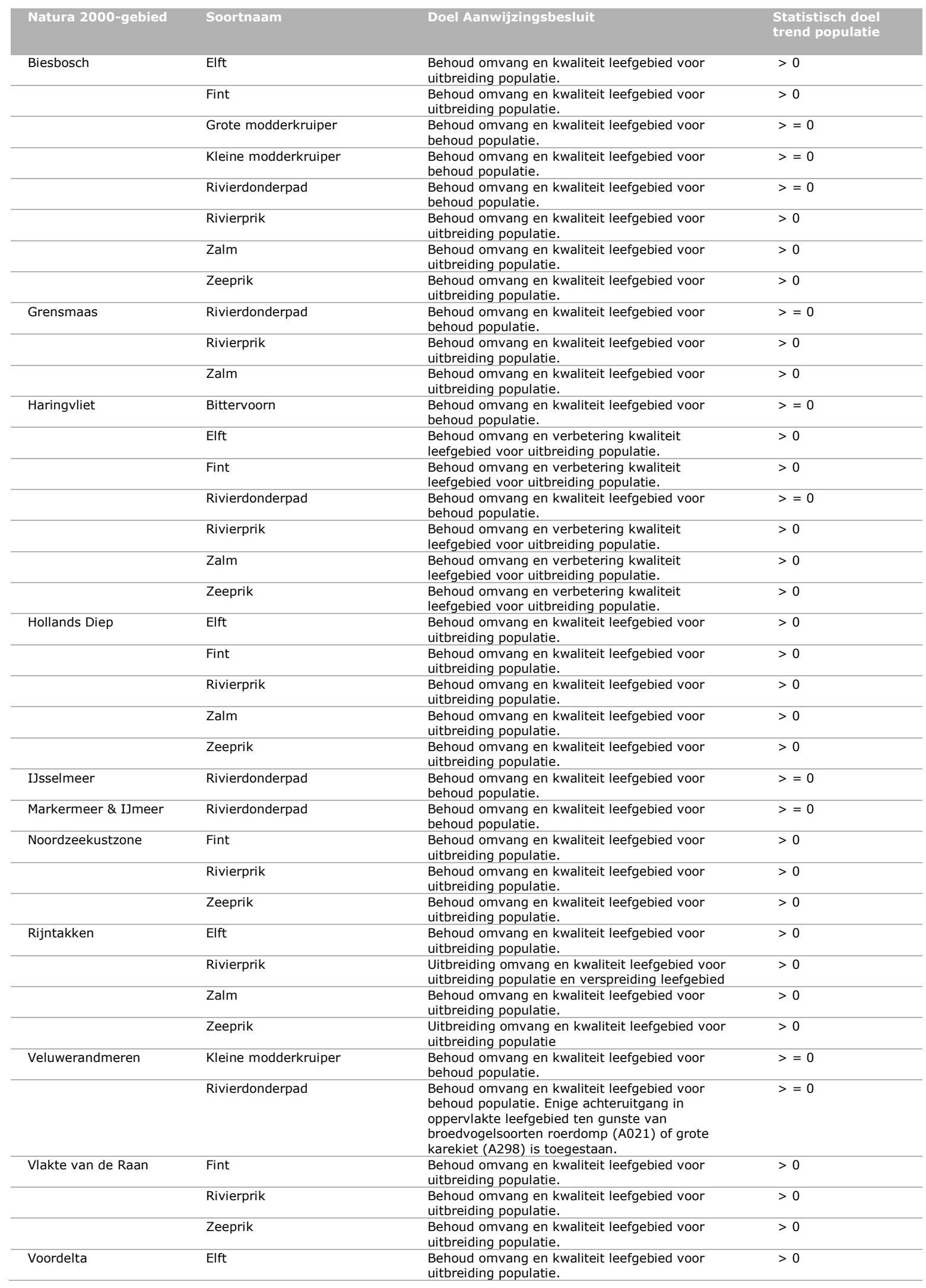




\begin{tabular}{|c|c|c|c|}
\hline \multirow[t]{4}{*}{ Natura 2000-gebied } & Soortnaam & Doel Aanwijzingsbesluit & $\begin{array}{l}\text { Statistisch doel } \\
\text { trend populatie }\end{array}$ \\
\hline & Fint & $\begin{array}{l}\text { Behoud omvang en kwaliteit leefgebied voor } \\
\text { uitbreiding populatie. }\end{array}$ & $>0$ \\
\hline & Rivierprik & $\begin{array}{l}\text { Behoud omvang en kwaliteit leefgebied voor } \\
\text { uitbreiding populatie. }\end{array}$ & $>0$ \\
\hline & Zeeprik & $\begin{array}{l}\text { Behoud omvang en kwaliteit leefgebied voor } \\
\text { uitbreiding populatie. }\end{array}$ & $>0$ \\
\hline \multirow[t]{3}{*}{ Waddenzee } & Fint & $\begin{array}{l}\text { Behoud omvang en kwaliteit leefgebied voor } \\
\text { uitbreiding populatie. }\end{array}$ & $>0$ \\
\hline & Rivierprik & $\begin{array}{l}\text { Behoud omvang en kwaliteit leefgebied voor } \\
\text { uitbreiding populatie. }\end{array}$ & $>0$ \\
\hline & Zeeprik & $\begin{array}{l}\text { Behoud omvang en kwaliteit leefgebied voor } \\
\text { uitbreiding populatie. }\end{array}$ & $>0$ \\
\hline \multirow[t]{3}{*}{$\begin{array}{l}\text { Westerschelde \& } \\
\text { Saeftinghe }\end{array}$} & Fint & $\begin{array}{l}\text { Behoud omvang en kwaliteit leefgebied voor } \\
\text { uitbreiding populatie. }\end{array}$ & $>0$ \\
\hline & Rivierprik & $\begin{array}{l}\text { Behoud omvang en kwaliteit leefgebied voor } \\
\text { uitbreiding populatie. }\end{array}$ & $>0$ \\
\hline & Zeeprik & $\begin{array}{l}\text { Behoud omvang en kwaliteit leefgebied voor } \\
\text { uitbreiding populatie. }\end{array}$ & $>0$ \\
\hline \multirow[t]{3}{*}{ Zwarte Meer } & Grote modderkruiper & $\begin{array}{l}\text { Behoud omvang en kwaliteit leefgebied voor } \\
\text { behoud populatie. }\end{array}$ & $>=0$ \\
\hline & Kleine modderkruiper & $\begin{array}{l}\text { Behoud omvang en kwaliteit leefgebied voor } \\
\text { behoud populatie. }\end{array}$ & $>=0$ \\
\hline & Rivierdonderpad & $\begin{array}{l}\text { Behoud omvang en kwaliteit leefgebied voor } \\
\text { behoud populatie. }\end{array}$ & $>=0$ \\
\hline
\end{tabular}




\section{Bijlage 2 Template evaluatie}

Hieronder wordt een indeling voorgesteld voor rapportages over de evaluaties per Natura 2000gebied.

\section{Rapportage Natura 2000 gebied}

\section{INLEIDING}

\section{Natura 2000 gebied}

Korte beschrijving Natura 2000 gebied

Datum aanwijzing Natura 2000 gebied

\section{Habitatrichtlijnsoorten}

HR Soort 1

HR Soort 2

HR Soort 3, etc.

Beschrijving ecologie per vissoort

\section{Instandhoudingsdoelstellingen}

Overzicht instandhoudingsdoelstellingen per soort

\section{Monitoring}

Beschrijving van vismonitoring in het gebied

\section{METHODE \& RESULTAAT}

Verwijzing naar algemene methodiek

Definitie onderzoeksvraag

Data exploratie

- Kaartje van Natura 2000-gebied met geselecteerde datapunten (in bijlage)

- Grafiek lange termijn

Analyse

Trends

- Grafieken met trends vanaf aanwijzingsbesluit

Conclusie analyse inclusief expert judgement

Overzichtstabel

Per gebied, voor alle soorten:

Tabel 14. Voorbeeldtabel. Evaluatie doelbereik. Periode evaluatie doelbereik: 2010-2018 voor de Voordelta, 2015-2018 voor het Haringvliet.

\begin{tabular}{lllll}
$\begin{array}{l}\text { Natura 2000- } \\
\text { gebied }\end{array}$ & Soort & ISD populatie & $\begin{array}{l}\text { Classificatie } \\
\text { populatietrend }\end{array}$ & $\begin{array}{l}\text { Evaluatie } \\
\text { doelbereik }\end{array}$ \\
\hline Hordelta & zeeprik & $>$ & Sterke toename & Doel gehaald \\
& rivierdonderpad & $=$ & Onzeker & $\begin{array}{l}\text { Haalbaarheid } \\
\text { doel niet te } \\
\text { bepalen aan de } \\
\text { hand van } \\
\text { huidige } \\
\text { monitoringsdata }\end{array}$ \\
\hline
\end{tabular}

\section{DISCUSSIE \& CONCLUSIE}




\section{Bijlage 3 Kaarten per Natura 2000-gebied}

Hieronder volgen kaarten van monitoringsstations voor de verschillende monitoringseries behorend bij de geselecteerde data. Doel is inzicht te geven waar data verzameld worden, t.o.v. de ligging van de Natura 2000-gebieden. Alle monitoringsjaren vanaf de aanwijzing als Natura 2000-gebied zijn geplot.

\section{Biesbosch}

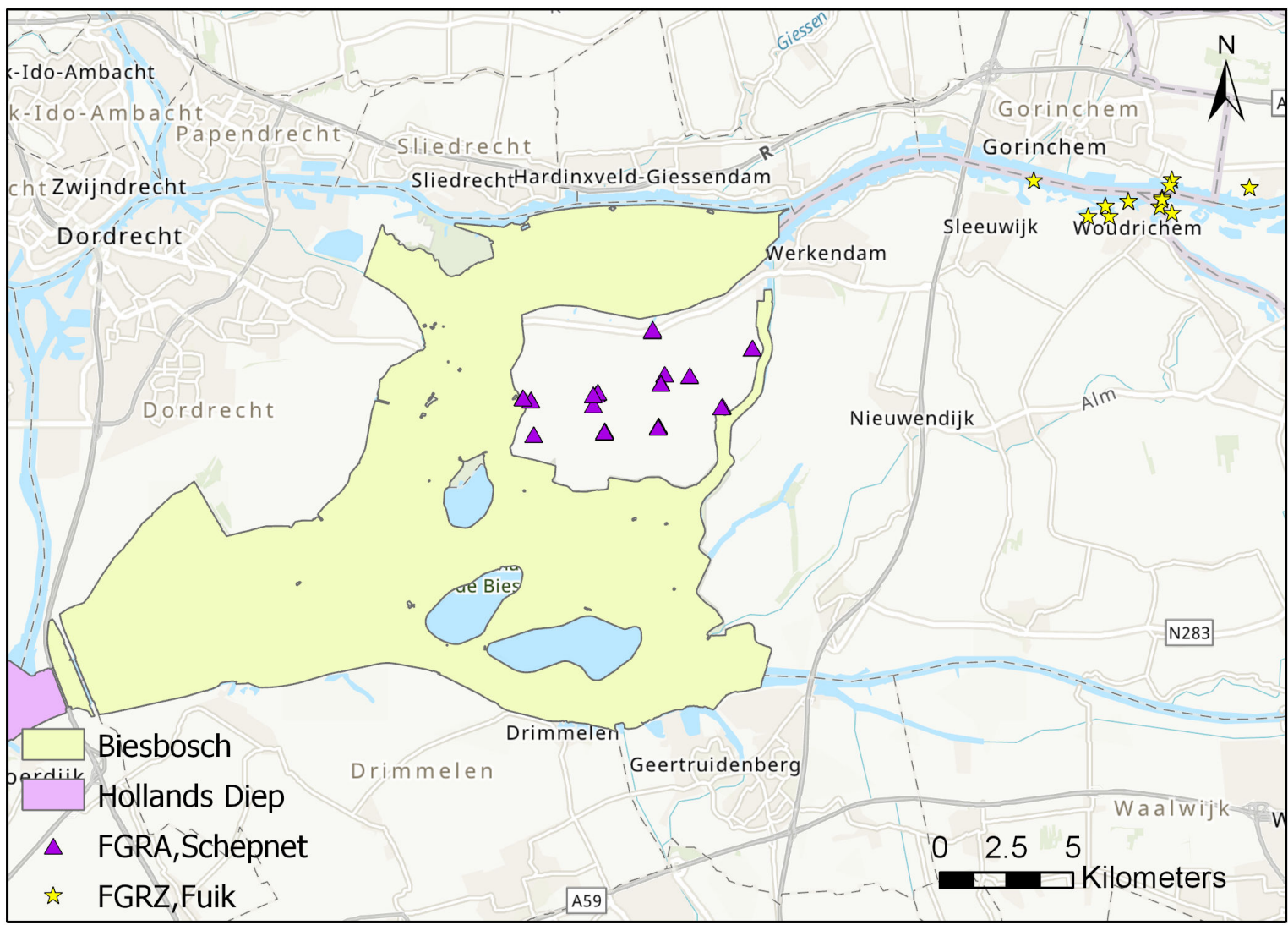

Figuur 6. Kaart met monitoringslocaties in en rondom Natura 2000-gebied de Biesbosch voor elft, zeeprik (IFFEZHEIM); rivierdonderpad, grote modderkruiper, kleine modderkruiper (FGRA) (deels in polderslootjes, op dit kaart lijkt dit land); en zalm (FGRZ). De vistrap bij IFFEZHEIM in Duitsland staat niet op deze kaart weergegeven. De monsterlocaties betreffen locaties bemonsterd vanaf het jaar van aanwijzing van het Natura 2000-gebied. 


\section{Grensmaas}

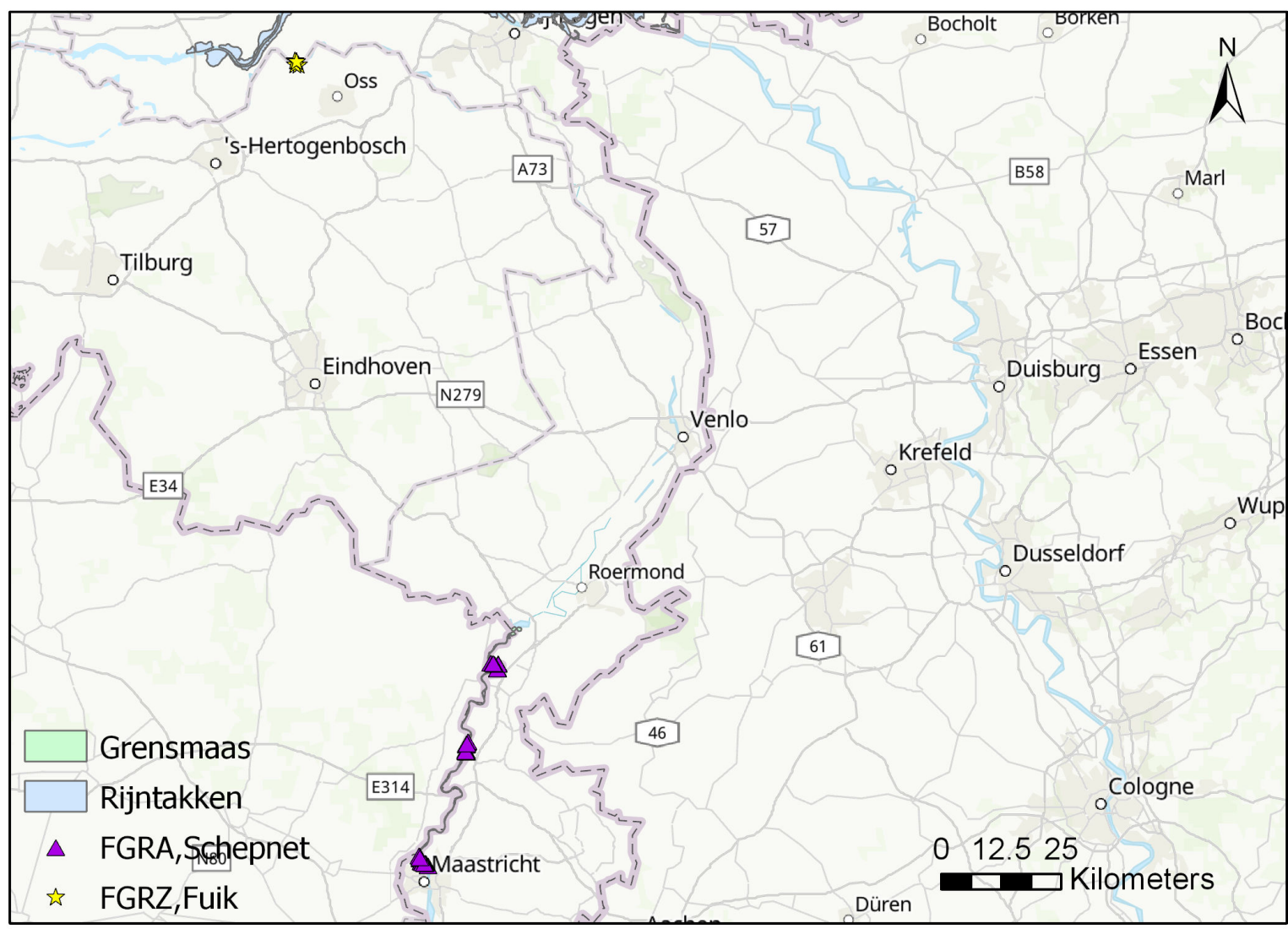

Figuur 7. Kaart met monitoringslocaties in en rondom Natura 2000-gebied de Grensmaas voor rivierdonderpad (FGRA) en zalm (FGRZ). De monsterlocaties betreffen locaties bemonsterd vanaf het jaar van aanwijzing van het Natura 2000-gebied. 


\section{Haringvliet}

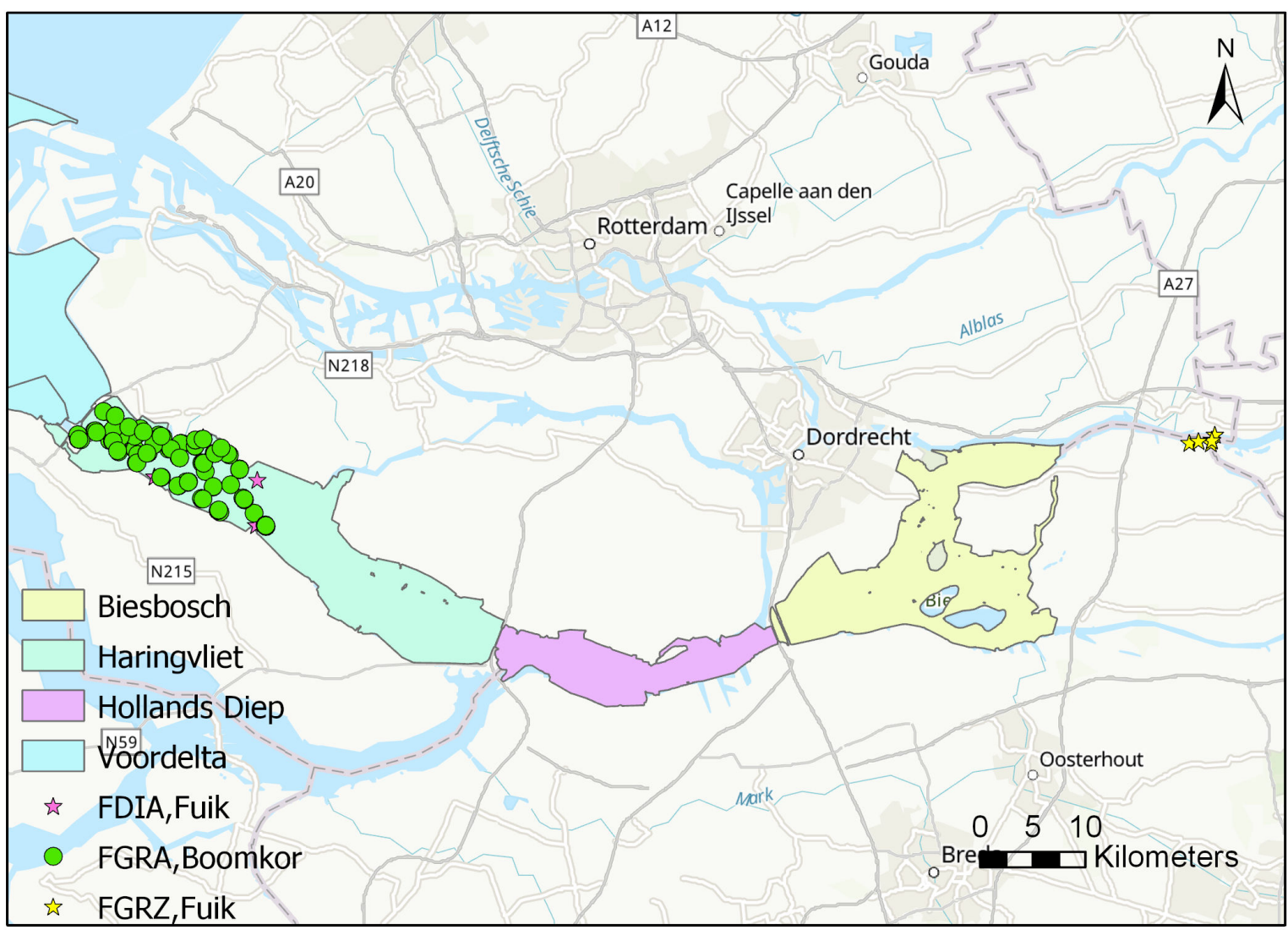

Figuur 8. Kaart met monitoringslocaties in en rondom Natura 2000-gebied Haringvliet voor elft, fint, rivierprik, zeeprik (FDIA); rivierdonderpad (FGRA); en zalm (FGRZ). De monsterlocaties betreffen locaties bemonsterd vanaf het jaar van aanwijzing van het Natura 2000-gebied. 
Hollands Diep

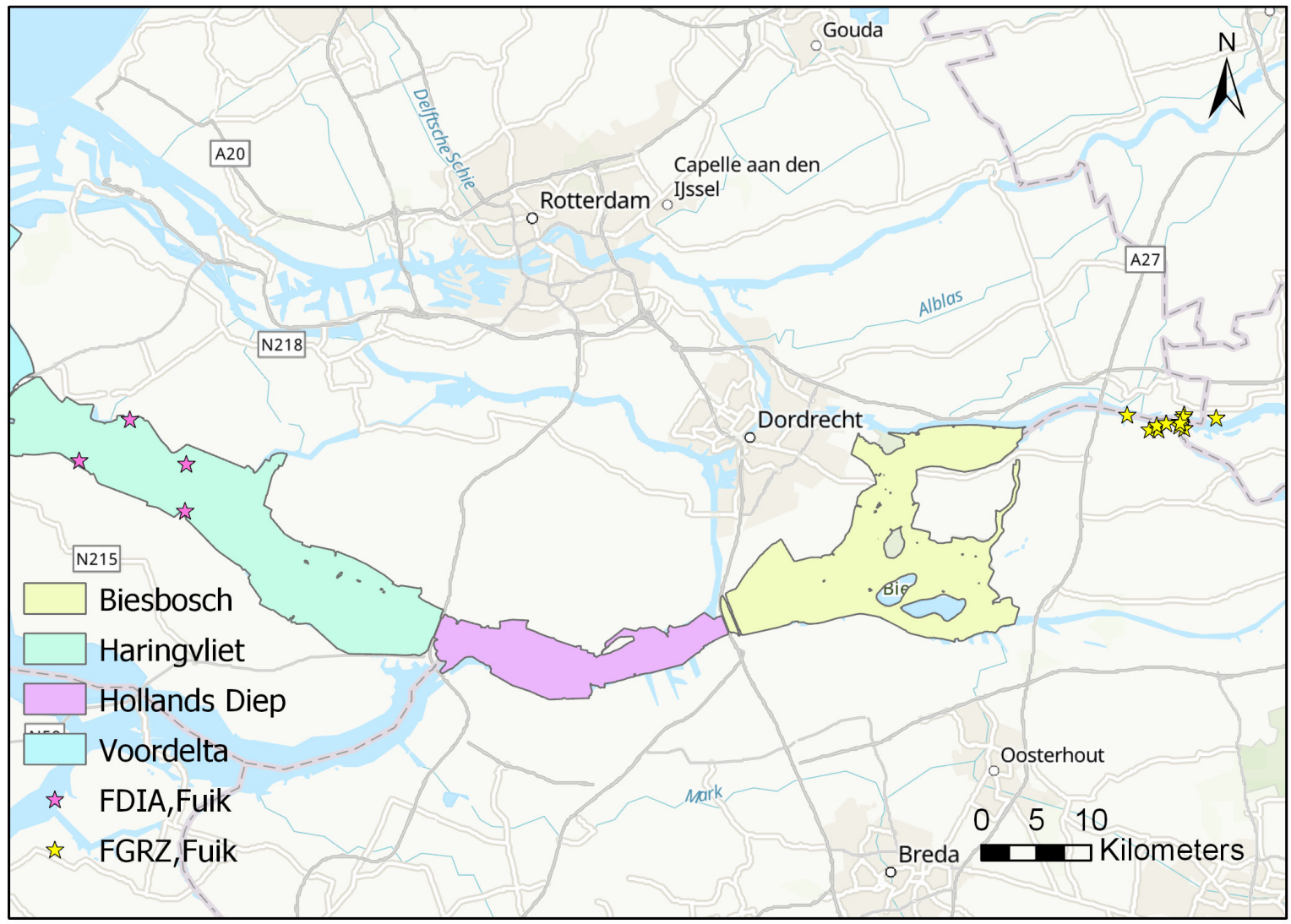

Figuur 9. Kaart met monitoringslocaties in en rondom Natura 2000-gebied Hollands Diep voor elft, fint, rivierprik, zeeprik (FDIA) en zalm (FGRZ). De monsterlocaties betreffen locaties bemonsterd vanaf het jaar van aanwijzing van het Natura 2000-gebied. 


\section{IJsselmeer}

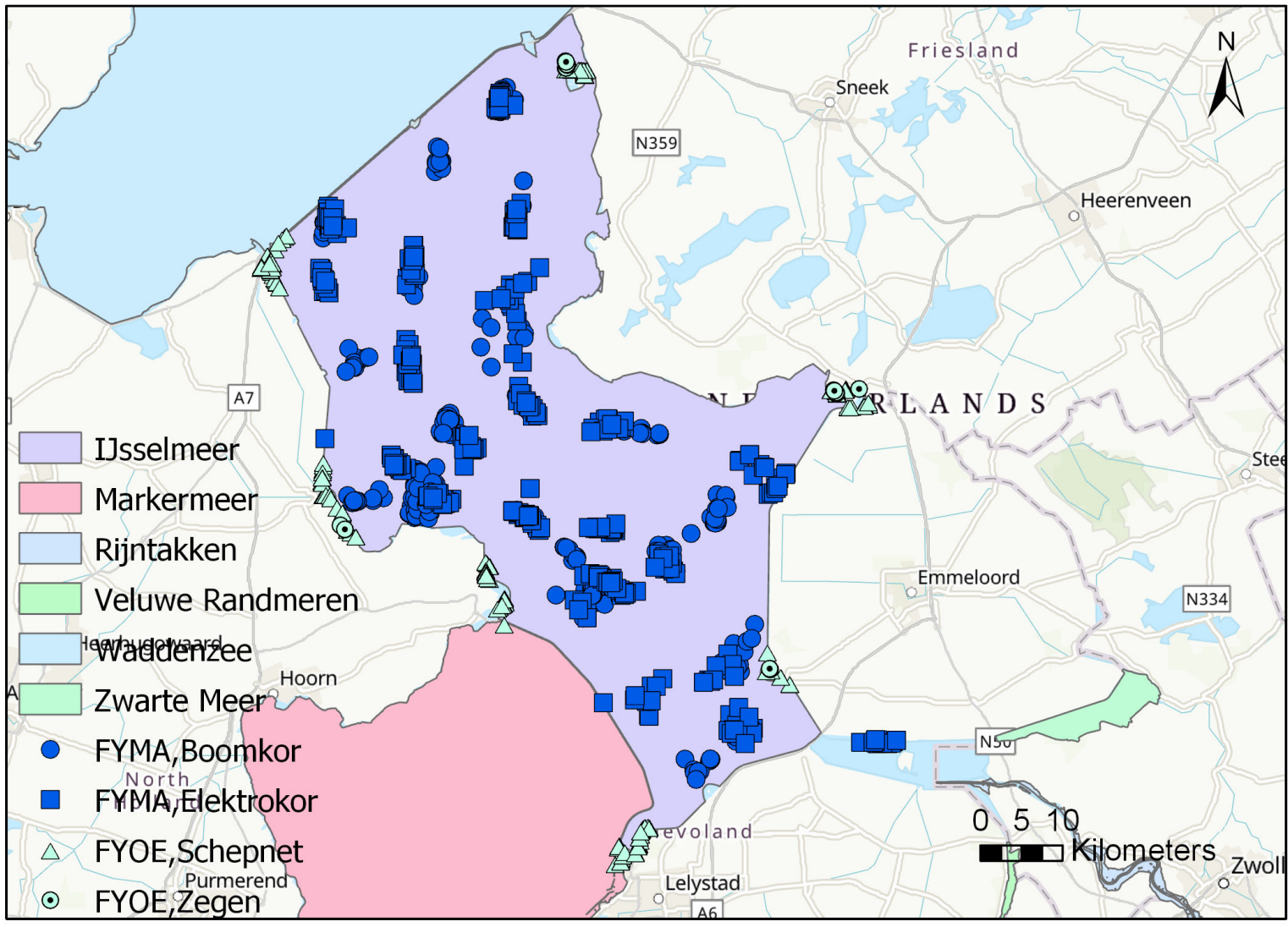

Figuur 10. Kaart met monitoringslocaties in en rondom Natura 2000-gebied IJsselmeer voor rivierdonderpad (FYMA \& FYOE). De monsterlocaties betreffen locaties bemonsterd vanaf het jaar van aanwijzing van het Natura 2000-gebied. 


\section{Markermeer \& IJmeer}

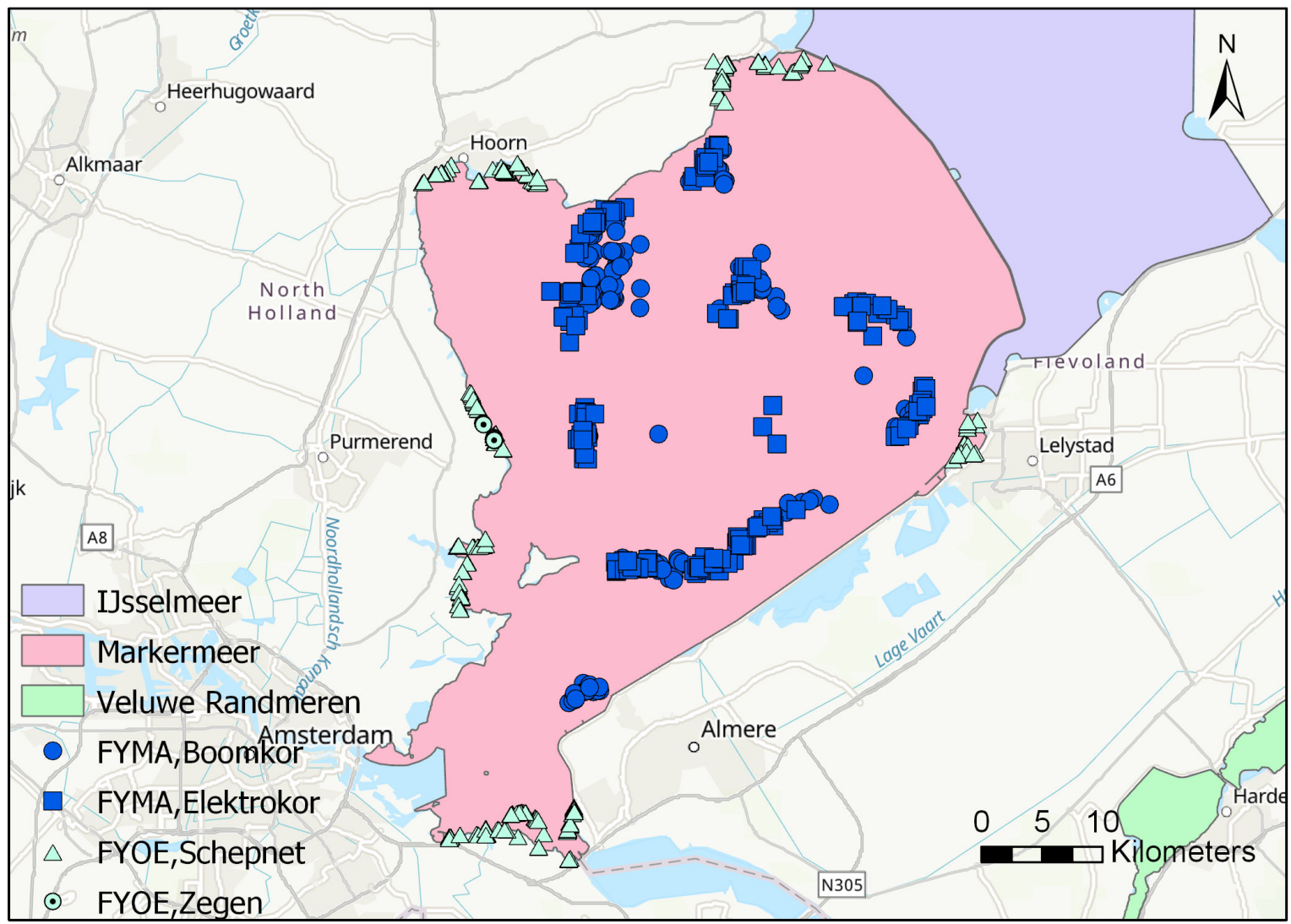

Figuur 11. Kaart met monitoringslocaties in en rondom Natura 2000-gebied Markermeer voor rivierdonderpad (FYMA \& FYOE). De monsterlocaties betreffen locaties bemonsterd vanaf het jaar van aanwijzing van het Natura 2000-gebied.

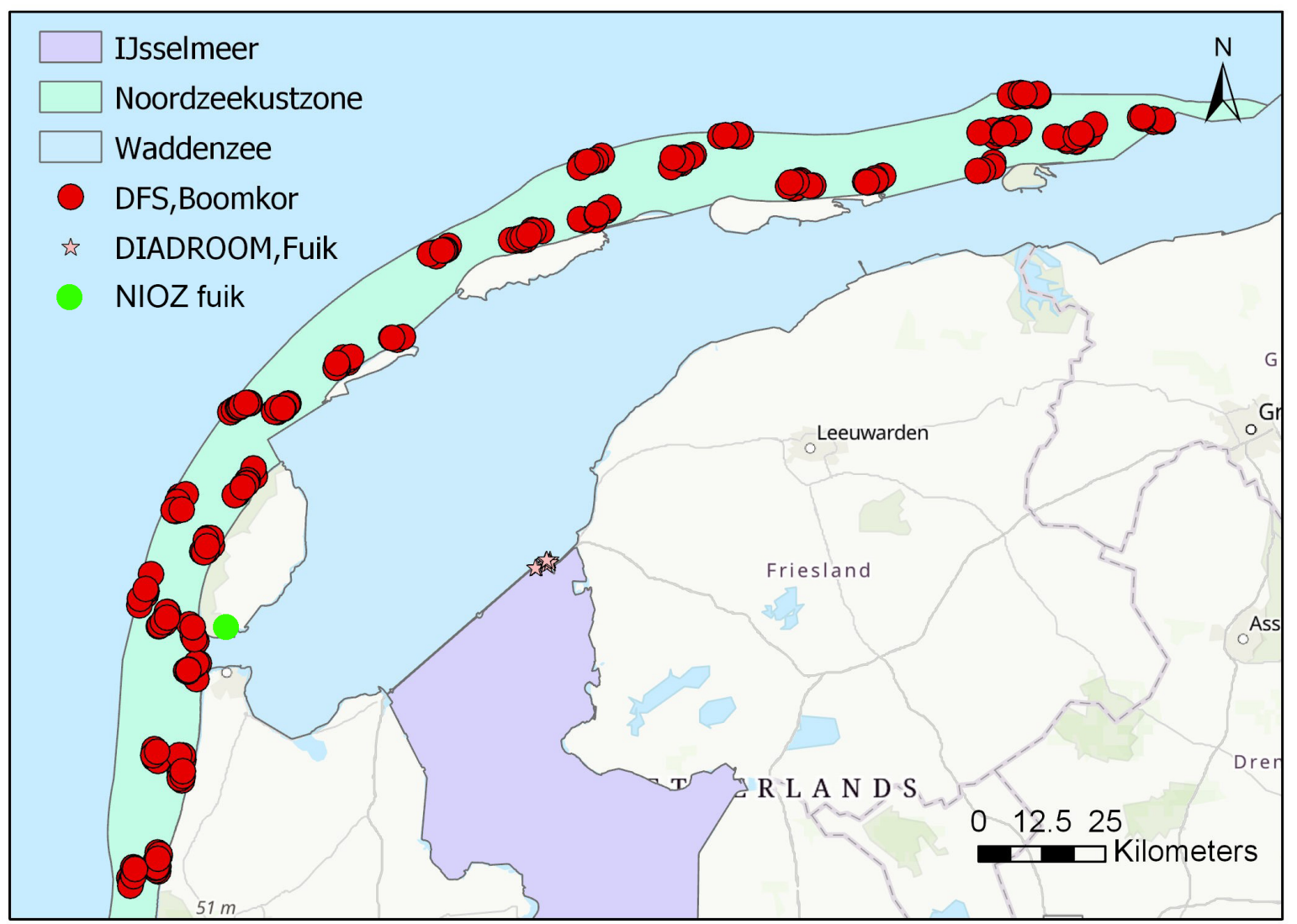

Noordzeekustzone

Figuur 12. Kaart met monitoringslocaties in en rondom Natura 2000-gebied Noordzeekustzone voor fint, rivierprik (DFS, DIADROOM, NIOZ FUIK) en zeeprik (DIADROOM, NIOZ FUIK). De monsterlocaties betreffen locaties bemonsterd vanaf het jaar van aanwijzing van het Natura 2000-gebied. 


\section{Rijntakken}

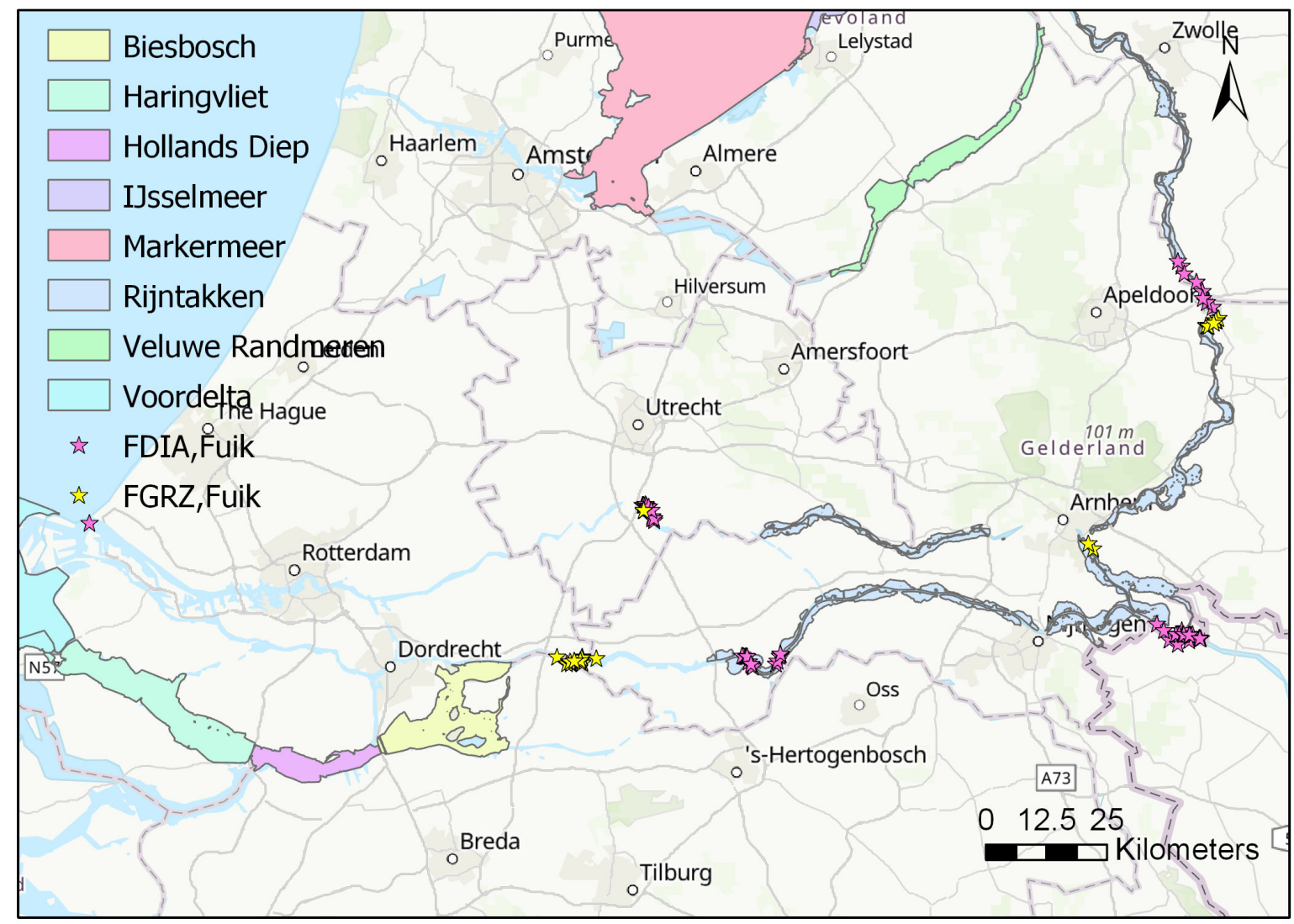

Figuur 13. Kaart met monitoringslocaties in en rondom Natura 2000-gebied Rijntakken voor elft, zeeprik (FDIA) en zalm (FGRZ). De monsterlocaties betreffen locaties bemonsterd vanaf het jaar van aanwijzing van het Natura 2000-gebied. 


\section{Veluwe Randmeren}

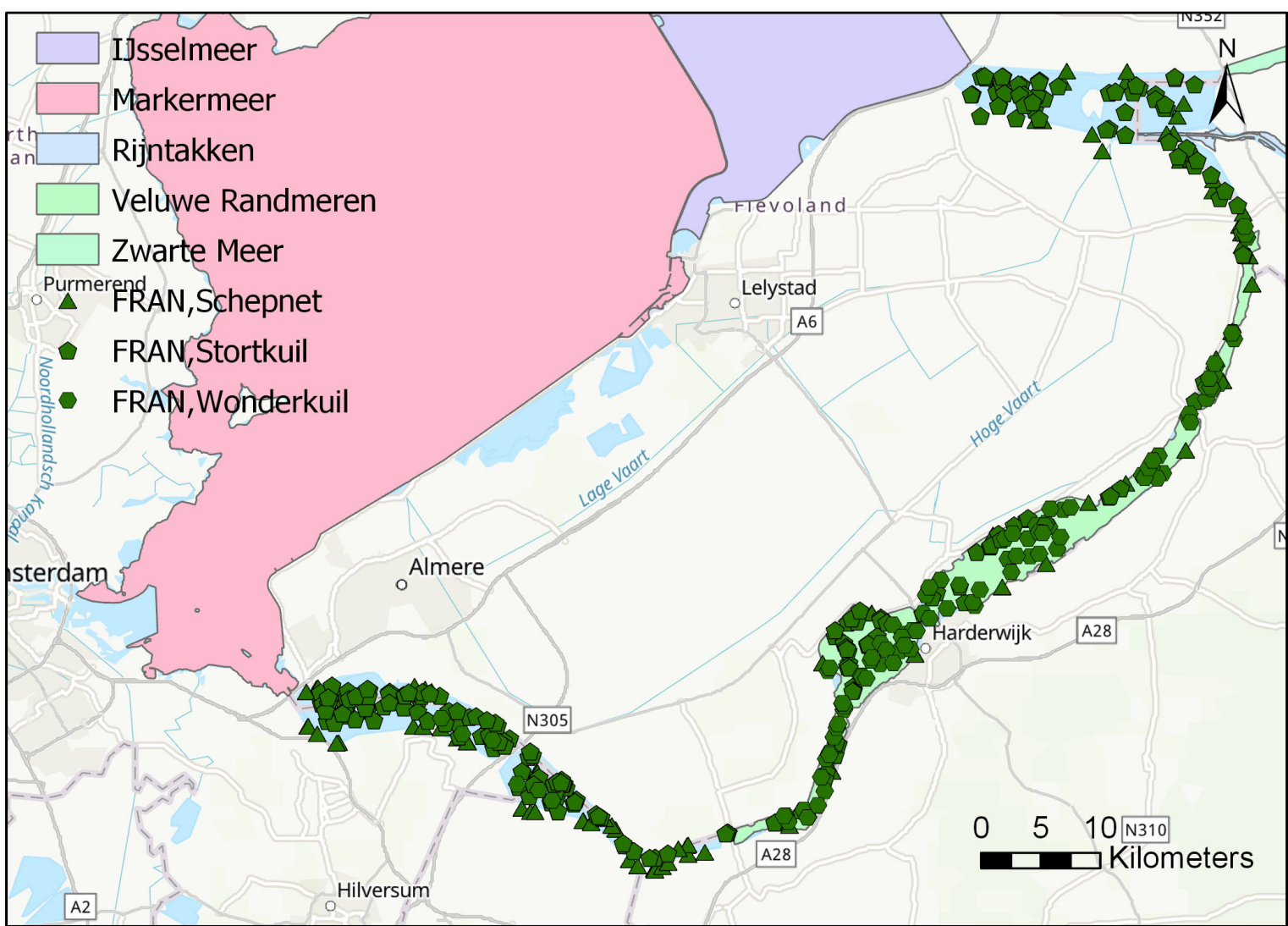

Figuur 14. Kaart met monitoringslocaties in en rondom Natura 2000-gebied Veluwe Randmeren voor rivierdonderpad en de kleine modderkruiper (FRAN). De monsterlocaties betreffen locaties bemonsterd vanaf het jaar van aanwijzing van het Natura 2000-gebied. 
Vlakte van de Raan

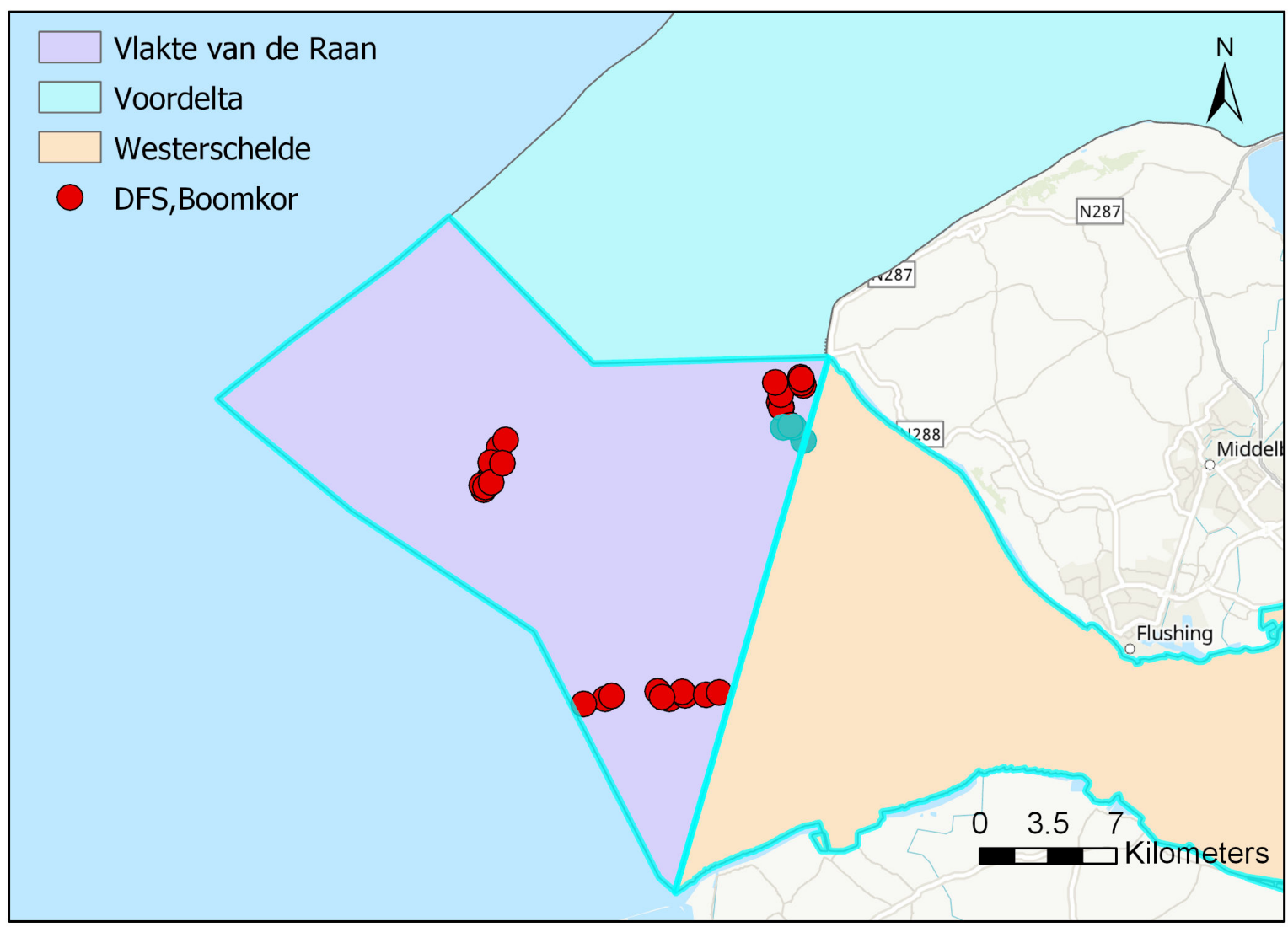

Figuur 15. Kaart met monitoringslocaties in en rondom Natura 2000-gebied Vlakte van de Raan voor fint en rivierprik (DFS). De monsterlocaties betreffen locaties bemonsterd vanaf het jaar van aanwijzing van het Natura 2000-gebied. 


\section{Voordelta}

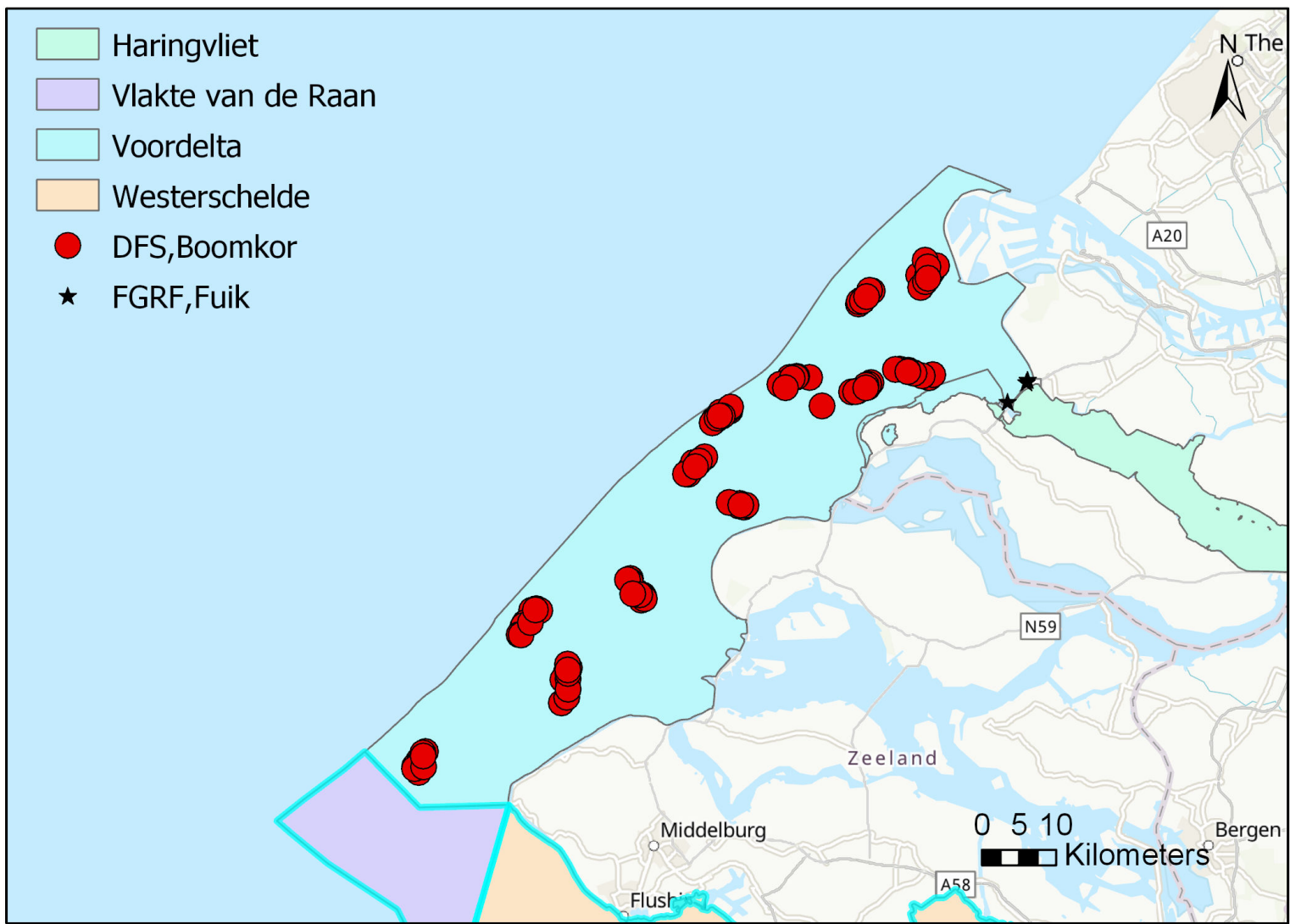

Figuur 16. Kaart met monitoringslocaties in en rondom Natura 2000-gebied Voordelta voor elft, fint, rivierprik (DFS, FGRF) en zeeprik (FGRF). De monsterlocaties betreffen locaties bemonsterd vanaf het jaar van aanwijzing van het Natura 2000-gebied. 


\section{Waddenzee}

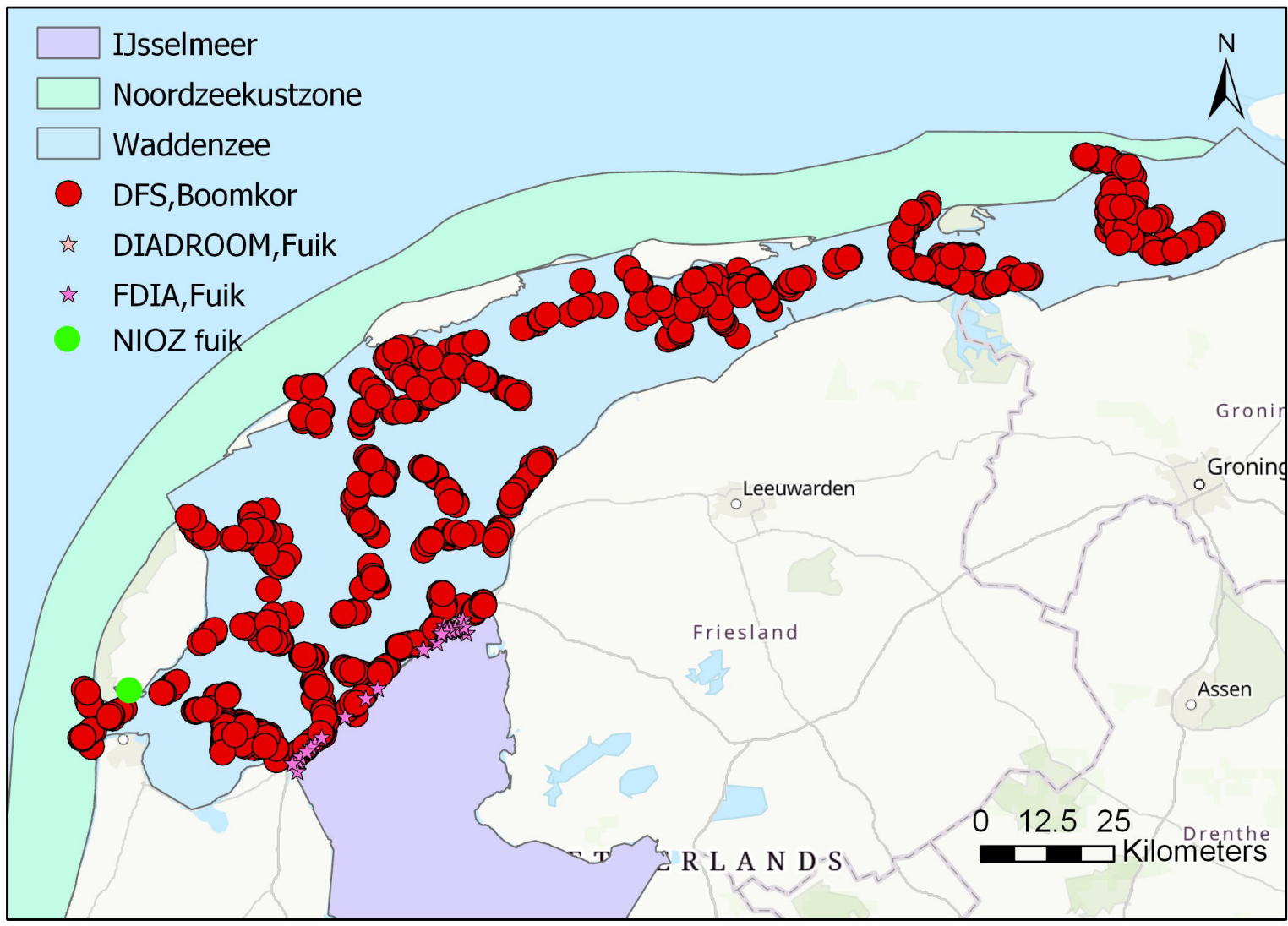

Figuur 17. Kaart met monitoringslocaties in en rondom Natura 2000-gebied Waddenzee voor fint (DFS, DIADROOM, NIOZ FUIK); rivierprik (DFS, DIADROOM, FDIA, NIOZ FUIK) en zeeprik

(DIADROOM, FDIA, NIOZ FUIK). De monsterlocaties betreffen locaties bemonsterd vanaf het jaar van aanwijzing van het Natura 2000-gebied. 
Westerschelde \& Saeftinghe

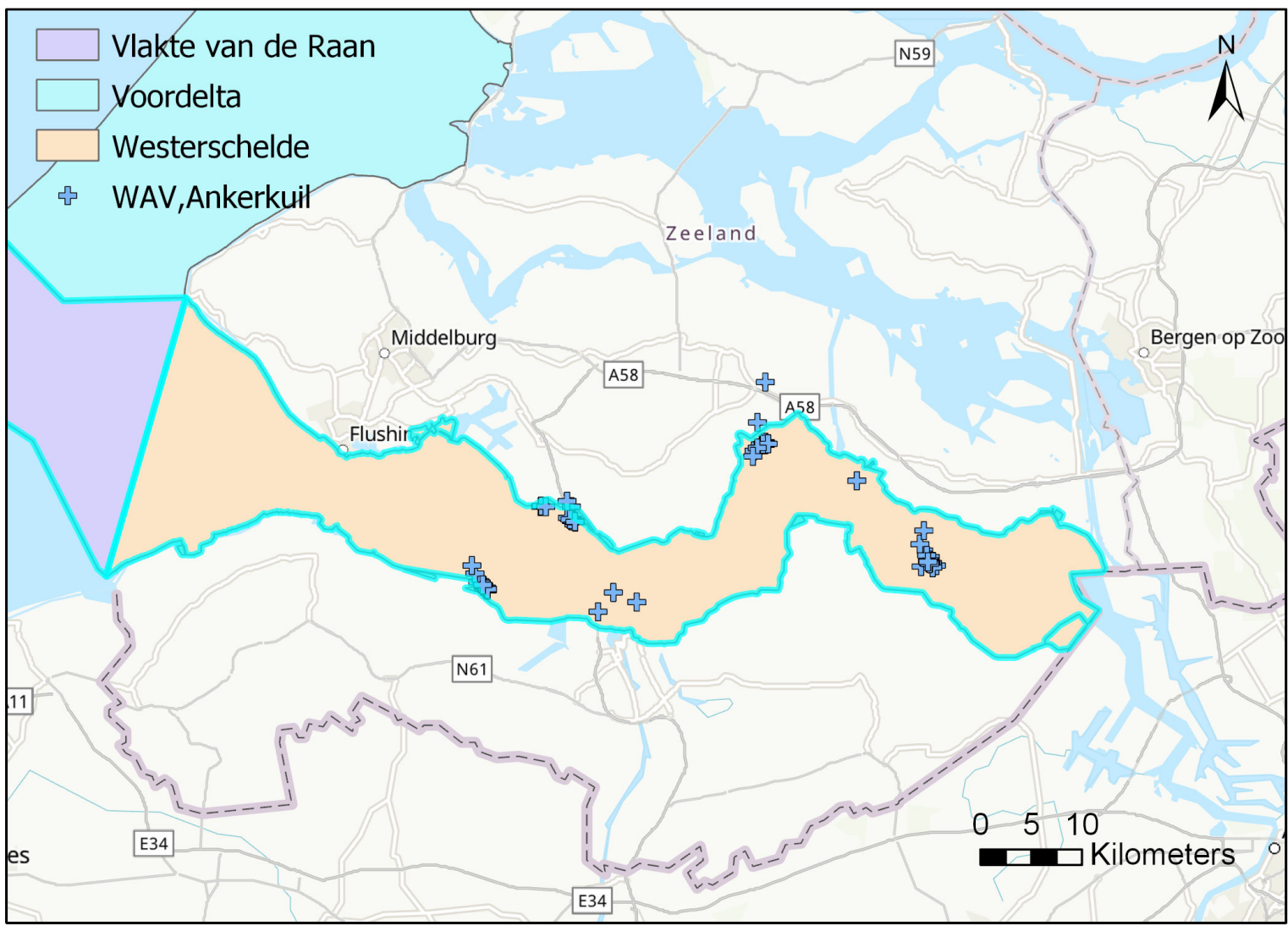

Figuur 18. Kaart met monitoringslocaties in en rondom Natura 2000-gebied Westerschelde voor fint, rivierprik en zeeprik (WAV). De monsterlocaties betreffen locaties bemonsterd vanaf het jaar van aanwijzing van het Natura 2000-gebied. 


\section{Zwarte Meer}

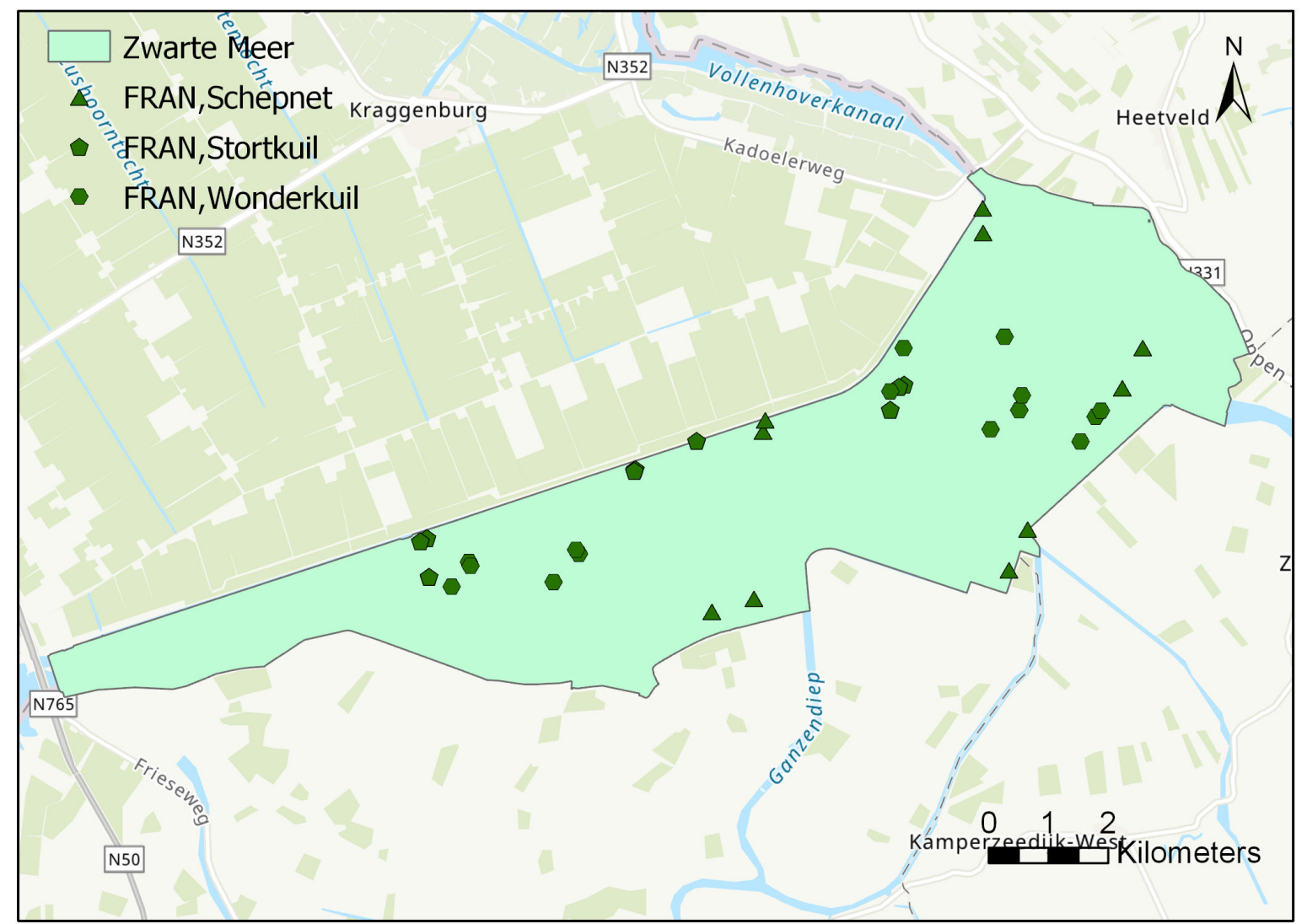

Figuur 19. Kaart met monitoringslocaties in en rondom Natura 2000-gebied Zwarte Meer voor rivierdonderpad, kleine modderkruiper, grote modderkruiper (FRAN). De monsterlocaties betreffen locaties bemonsterd vanaf het jaar van aanwijzing van het Natura 2000-gebied. 
Wageningen Marine Research

T: $+31(0) 317480900$

E: marine-research@wur.nl

www.wur.nl/marine-research

Bezoekers adres:

- Ankerpark 271781 AG Den Helder

- Korringaweg 7, 4401 NT Yerseke

- Haringkade 1, 1976 CP IJmuiden
Wageningen Marine Research levert met kennis, onafhankelijk wetenschappelijk onderzoek en advies een wezenlijke bijdrage aan een duurzamer, zorgvuldiger beheer, gebruik en bescherming van de natuurlijke rijkdommen in zee-, kust- en zoetwatergebieden.
Wageningen Marine Research is onderdeel van Wageningen University \& Research. Wageningen University \& Research is het samenwerkingsverband tussen Wageningen University en Stichting Wageningen Research en heeft als missie: 'To explore the potential of nature to improve the quality of life' 